


\section{PUBLIC LIBRARY}
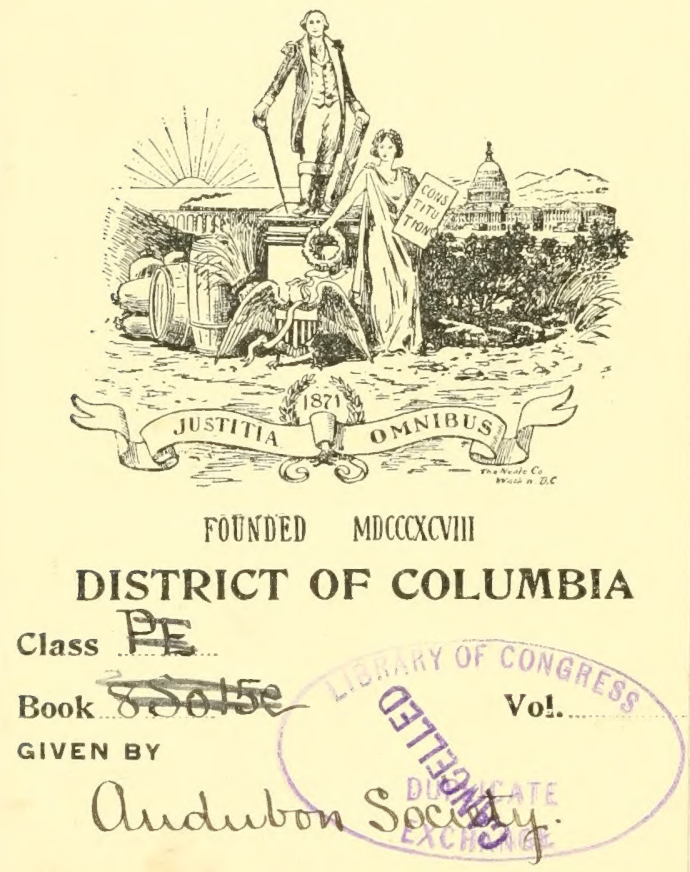



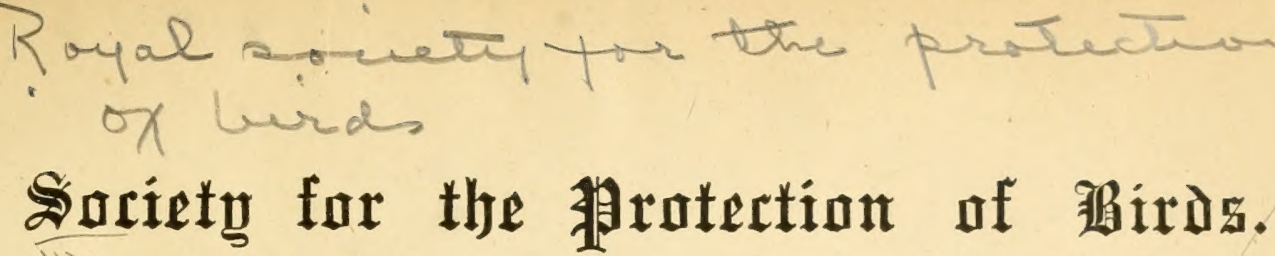

EDUCATIONAL SERIES. Edited by H. E. DRESSER, F.L.S., F.Z.S.

\section{No. I. -OWLS.}

\section{By MONTAGU SHARPE, Vice-Chairman Middx. C.C.}

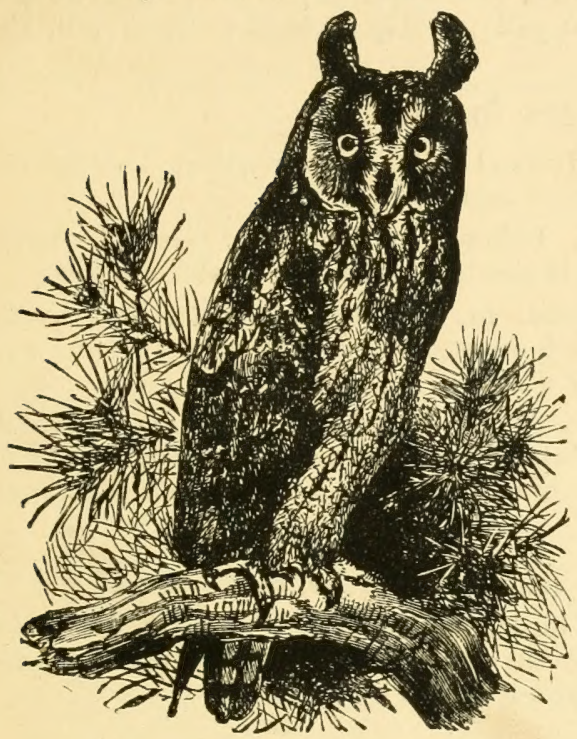

LONG-EARED OWL.

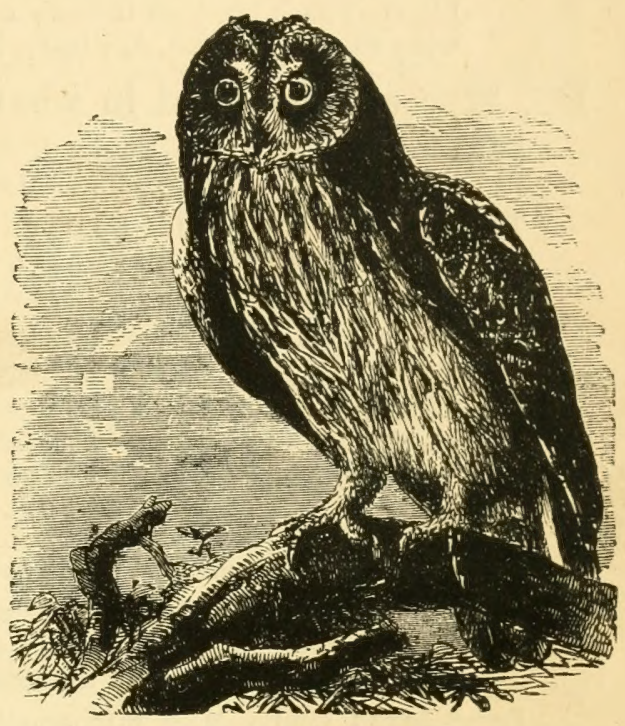

SHORT-EARED OWL.

"Was by a mousing owl hawked at and killed."-Shakespeare.

\section{Name-OWL.}

Family-Strigidæ.
Genus-1. Strix.
S. flammea. Barn or White Owl.
2. Syrnium.
S. aluco. Wood Brown or Tawny Owl.
3. Asio.
A. otus. Long-Eared Owl.
A. brachyotus. Short-Eared Owl.

\section{General Description and Proportions in Inches.}

Barn or White Owl.-Upper parts orange buff, pencilled with grey and spotted with blackish grey and white, face and under parts white, bill pale yellow, feet generally with bristles, claws black. Tip of beak to tip of tail, 13; wing closed, 11 ; tail, 5 ; body, 7.

Tawny or Wood $\mathbf{O w l}$ - - Upper parts reddish brown, spotted with darker brown and blackish; lower parts buffish white mottled with brown, and streaked with dusky brown; legs feathered, claws whitish at base. Tip of beak to tip of tail, 18; wing closed, 12 ; tail, 7 ; body, $9 \frac{1}{2}$.

Illustrations by Ioseph Wolf, from " British Birds in their Haunte," by kind permission of Society for

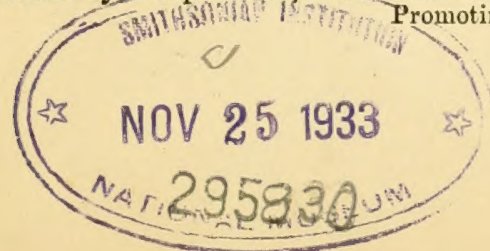


Long-Eared Owl.--Upper parts buff, mottled with brown of various shades; ear tufts large and composed of black feathers edged with buff; the under parts are of a lighter buff, with broad streaks of deep brown and faint transverse bars of paler brown; beak and claws dark horn colour; irides rich orange yellow. Tip of beak to tip of tail, 14; wing closed, $11 \frac{1}{2}$; tail, $5 \frac{3}{4}$; body, $7 \frac{1}{4}$.

Short-Eared Owl.-General colour dark buff; wings and tail barred with lark brown, the rest of the plumage, except thighs and under tail coverts, streaked and blotched with blackish brown; irides bright yellow. Tip of beak to tip of tail, 15; wing closer, 12 ; tail, $5 \frac{3}{4}$; body, $8 \frac{1}{4}$.

\section{Where, when, and in what Numbers found.}

Barn or White Owl.-England, Scotland, Ireland. Constant resident throughout the year. Formerly common, but now rare in many places.

Tawny or Wood Owl.-England, Scotland, Ireland, in denselv wooded discricts Constant resident. Incessant persecution is slowly producing its extermination.

Long-Eared Owl.-England, Scotland, Ireland, in woodland districts, and in fir plantations. Is a partial migrant. If not erroneously regarded as vermin, and destroyed accordingly, might become fairly common.

Short-Eared Owl.-England, Scotland, Ireland, on moorlands and marshes. A regular winter visitor-generally a migratory bird, but resident in some parts of

\section{Food.}

Scotland. More common in the fen districts and northern counties than elsewhere.

Barn 0wl.-Bats, small birds, dormice, mice, voles, rats, shrews, water rats.

Tawny or Wood Owl.-Beetles, small birds, cockchafers, mice, voles, rats, shrews, water rats, occasionally a young game-bird or rabbit. Any misdeeds are small in comparison with the good practical work done by this bird.

Long-Eared Owl--Mice, rats, small birds, voles.

Short-Eared Owl.-Mice, rats, shrews, voles, occasionally birds and beetles.

An examination of pellets from the barn, tawny, and long-eared owls yielded the following remarkable results:-

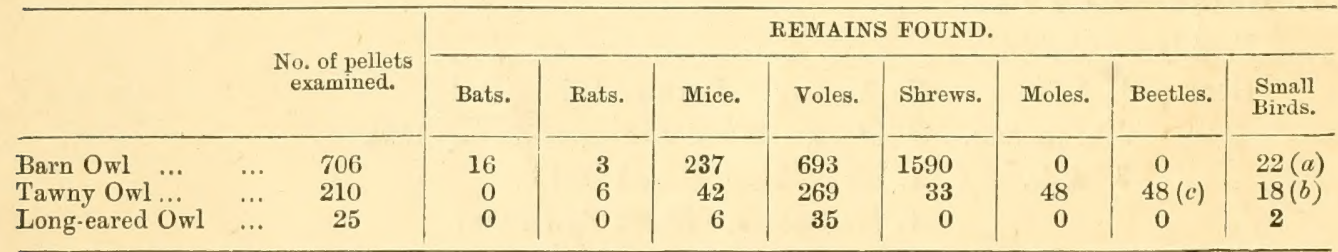

\section{Y. Characteristics.}

(a) Nineteen sparrows, a greenfinch, and two swifts.

(b) Wifteen small species undetermined, a wagtail, a treecreeper, and a yellow bunting.

Owls have the peculiar habit of ejecting pellets from the mouth containing the indigestible remains of the food they have swallowed. They are able to see in the night-time, and possess a noiseless flight, necessary on account of the lieen sense of hearing possessed by their prey, viz., mice and rats, etc.

The Barn Owl's usual note is a screech, and at times a snore.

The Tawny Owl is a dull and sombre bird, seeking seclusion in its gloomy forest haunt. It utters a clear and loud hoot.

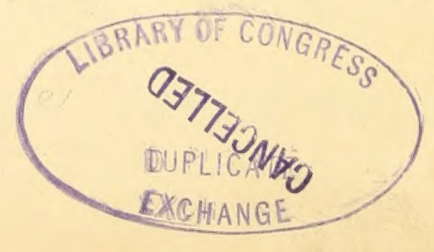


The Long-Eared $\mathrm{Owl}_{\mathrm{wl}}$ is less strictly nocturnal in its habits.

The Short-Eared $\mathrm{Owl}$ may be seen quartering the ground at all hours of the day. Where great plagues of mice have occurred this species has been known to flock in numbers to the place.

\section{Protection.}

Wild Birds Act, 1880.-These birds appear in the schedule, which applies to every county in England, Scotland, and Ireland. Any owner, occupier, or other person taking, killing, etc., an owl during close season,* or possessing or selling an owl after 15th March, is liable to a penalty of $£ 1$ for each bird.

Wild Birds Act, 1894.-Their eggs are protected at present (1896) in the following counties : $\nmid$ -

ENGLAND-I. Northern : Durham, Cumberland, Westmoreland; II. Miduand : Bedford, Chester, Derby, Gloucester, Huntingdon, Leicester, Lincoln (parts of Kesteven and Lindsey), Northampton, Stafford, Warwick, and West Suffolk; III. Southern : Devon, Hertford, Isle of Wight, Metropolitan Police District (including London and Middlesex), Norfolk, Oxford, Southampton.

SCOTLAND-Aberdeen, Berwick, Dumfries, Kircudbright, Wigtown, Orkney, Shetland, East Haddington, Linlithgow, Islay, Jura, Colonsay, and Tiree.

IRELAND-Roscommon.

Anỳ owner, occupier, or other person taking or destroying an owl's egg is liable to a penalty of $£ 1$ for each egg. The eggs of the four species are pure white, nearly round, and measure about $1 \frac{1}{2}$ by $1 \frac{1}{4}$ inches, those of the Tawny Owl being somewhat larger.

\section{Remarks.}

It was a wise legislative proceeding that granted protection to owls, for of all birds, from a farmer's standpoint, they are among the most useful, and are placed in the highest class by the economist. Will no one explain to the whole generation of gamekeepers what a stupid and aimless crime is the wholesale persecution of these pleasing birds?

Half a dozen pole-traps in use on one estate will keep down and even exterminate the owls inhabiting the country for miles around. Richard Jefferies relates that in one instance no fewer than two hundred owls were taken in one pole-trap in a plantation of young fir trees, doubtless held fast by their crushed legs, and doomed to perish miserably by slow degrees! Two hundred convictions at $£ 1$ each, with costs, would be a large sum to pay for using that pole-trap!!

Our ancestors, wiser than we are, always made in their great barns an ingress for owlsan owl hole, with often a stone perch. If you do not possess a hollow tree, why not construct a suitable place and try to induce a pair of barn owls to reside on your premises?

* Generally from 1st March to 31st July; but in some counties from 1st February to 31st August in each year.

+ It is expected that other counties will before long obtain similar orders of protection under the Act of $189 \mathrm{t}$. 
"I made a place with stone and mortar, about four feet square, and fixed a thick oaken stick tirmly into it. Huge masses of ivy now quite cover it. In about a month or so after it was finished a pair of barn owls came and took up their abode in it. I threatened to strangle the keeper if ever after this he molested either the old birds or their young ones. . . . . This year I have had four broods. . . . . and it will help to supply the place of those which in this neighbourhood are still unfortunately doomed to death."-CHarLes Waterton.

When farmers complain that the barn owl destroys the eggs of their pigeons they lay the saddle on the wrong horse. They ought to put the blame on the rat. If it were really an enemy of the dovecot we should see the pigeons in commotion as soon as it begins its evening flight.

All day long, while the owls are snoozing and blinking in holes and corners, the kestrel keeps quartering the fielảs with the eyes of a lynx for mice and cockchafers. At night the owl takes up the good work of the kestrel, as the bats continue that of the swallow in the destruction of insects.

Owls, it has been said, ought to be as common as rooks; they should be tempted in every way to live amongst us, and a reward should be given to every farm hand who brought first news of a nest upon the grounds. The remissness and ignorance of proprietors and keepers in the matter is so extraordinary, that, before a change can take place, the owl is likely to be altogether extinct. In Scotland I have heard they have positively been driven to importing owls from the Continent to cope with the mice.

Owls are lynx-eyed cats with wings, and the benefit they confer upon agriculturists is almost incalculable. There are ten tiny creatures-four mice, three voles, three shrewswhich, if not kept under, would quickly devastate our fields. Many English counties have been overrun by hordes of rodents, which, in many cases, have done very considerable damage.

It has been computed that an owl, when it has young, will bring a mouse, etc., to its nest every fifteen minutes.

Where, in game-preserving districts, owls have been shot down and exterminated, the inevitable results have followed, viz., swarms of rats and mice, in such numbers as to constitute a plague.

Owls and kestrels are frequently attracted to game coverts by the number of rats and mice to be found there, in consequence of the food laid down for the game birds. Therefore, from the game-preserver's standpoint, the destruction of birds of prey-owls, especially-is a short-sighted policy, as the two live well together.

(The above leaflet is chiefly extracted from the following works :- "British Birds," Seebohm; "Ornithology in relation to Agriculture, etc.," Watson; "The Barn Owl," W. H. Hudson; "Our Country's Birds," W. J. Gordon.)

Educational Series, $1 \frac{1}{2} d$. per 6 copies, post free. No. I.-OWLS. No. II.-WOODPECKERS. Others in course of prepuration.

Pamphlets on the general question of Protection of Birds may also be obtained from the Society's Publishing Department, Knowledge Office, 326, High Holborn, London, W.C., or of Mrs. F. E. LEMON Hon. Sec., Hillerest, Redhill, Surrey.

Special terms for County Councils and Educational Authorities.

The Sosiety's Publishing Office, Knowledge, 326, High Holborn, London, W.C. 1896. 


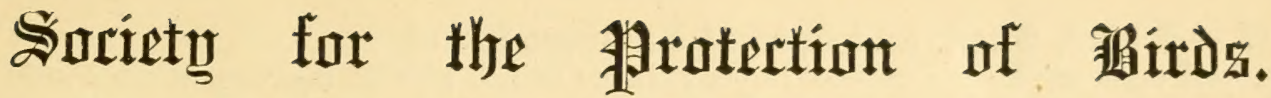

EDUCATIONAL SERIES. Edited by H. E. DRESSER, F.L.S., F.Z.S.

\section{No. 2.-WOODPECKERS.}

By Sir HERBERT MAXWELL, BART., M.P., etc.

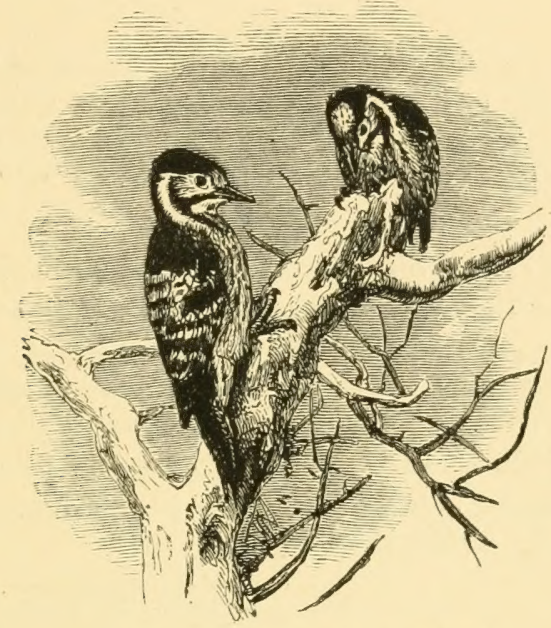

LESSER SPOTTED WOODPECKER.

\section{Name-WOODPECKER.}

Family-Picidx.

Genus-1. Dendrocopus. Dendrocopus major. Great Spotted Woodpecker.

Dendrocopus minor. Lesser Spotted Woodpecker.

\section{II.-General Description.}

Great Spotted Woodpecker.-Crown and upper parts black, a crimson patch on the back of the head, a white spot on each side of the neck; scapulars, lesser wing coverts, and under parts white; belly and under tail coverts crimson. (Female without crimson on head.) Length, $9 \frac{1}{2}$ in. ; wing closed, $5 \frac{3}{4}$ in. ; tail, $4 \mathrm{in}$.

Lesser Spotted WoOdPecker.-Forebead and lower parts dirty white ; crown bright red; nape, back, and wings black with white bars; tail black, the outer feathers tipped with white and barred with black; iris red. (Female without crimson on head.) Length, $5 \frac{1}{2}$ in. ; wing closed, $3 \frac{3}{4}$ in. ; tail, $2 \frac{1}{2}$ in.

Green Woodpecker.-Upper parts olive green; rump yellow; under parts greenish grey ; crown, back of the head, and moustaches crimson; face, black. (Female less crimson on the head; moustaches black.) Length, 13. in. ; wing closed, $6 \frac{1}{4}$ in. ; tail, $4 \frac{1}{4}$ in.

Illustration from "British Birds in their Haunts," by Johns. By kind permission of the Society for Promoting Christian Knowledge. 


\section{III.-Where, when, and in what Numbers found}

All three species are resident throughout the British Islands, but rare in the North of England, Scotland, and Ireland. On the East Coasts of England and Scotland the numbers of the Great Spotted Woodpecker are considerably increased during the season of migration. It is doubtful if the Green Woodpecker occurs in Scotland. All three species are residents.

\section{IV.-Food.}

Principally insects found in the crevices of barks and decayed wood of trees ; also nuts, acorns, \&c., and occasionally fruit and seed. The Green Woodpecker feeds also largely on ants and their pupæ.

\section{У. Characteristics.}

The Woodpeckers are shy, restless birds, frequenting groves and wooded districts, where they may be seen flying from tree to tree, examining the bark or tapping the decayed branches in search of their insect food. They nest in holes, which they excavate in soft-wooded trees, and deposit pure white, very glossy, eggs, which are slightly pyriform in shape.

\section{Protection.}

Wild Birds Act, 1880.-These birds appear in the Schedule.

Wild Birds Act, 1894.-The eggs are protected in the following Counties :-

ENGLAND-(1) Cumberland, Durham ; (2) Bedford, Gloucester, Huntingdon, Lincoln (parts of Kesteven and Lindsey), Northampton, Stafford, Warwick, and West Suffolk ; (3) Devon, Hertford, London and Metropolitan Police District, Southampton. SCOTLAND_Berwick, Dumfries, Kircudbright, and Wigtown.

IRELAND-Any owner, occupier, or other person taking or destroying a Woodpecker's egg, penalty £1 for each egg.

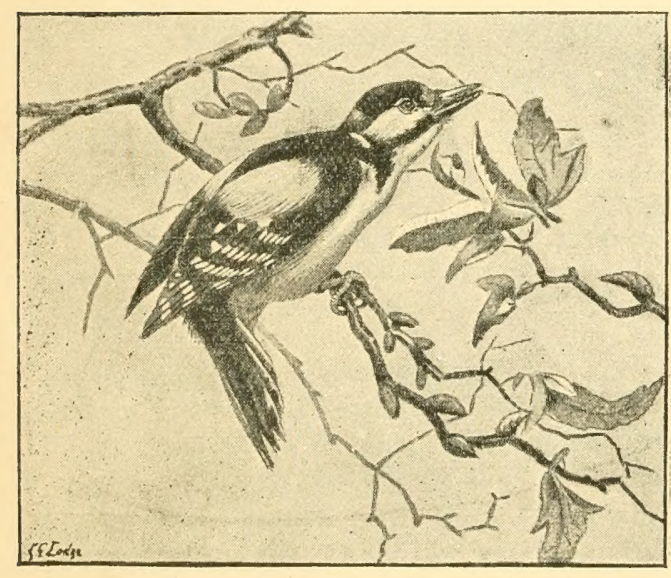

GREAT SPOTTED WOODPECKER.

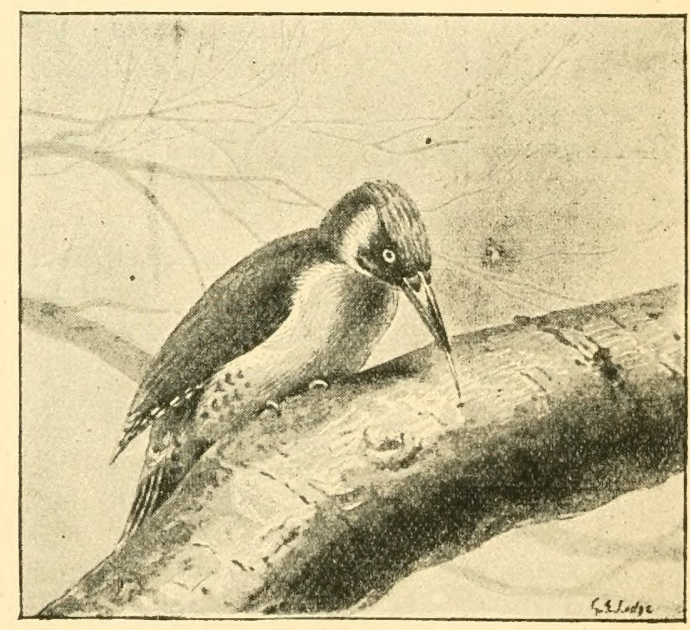

GREEN WOODPECEER.

\section{VII.-Remarks.}

There is no more trustworthy herald of Spring than the Green Woodpecker, or Yaffle, as English countrymen call this handsome bird. February sunshine often beguiles the throstle and the merle into fallacious song, and let no wayfarer leave his wraps because the ringdove coos smooth assurance from the elm. There is no trust to be placed in these; but

Illustrations, by kind permission of Messrs. Longmans, Green, \& Co., from "British Birds," by IV. H. Hudson. C.M.Z.S. 
as soon as you hear the Yatlle's laughing note you may be sure the sap is rightly astir, and that presently the grove will be dim with new greenery. The jay, harshly garrulous at other times, falls cunningly silent in the nesting season, but the Yaflle cannot hold his tongue in the honeymoon.

This is one of those pretty birds that run heavy rislis by reason of their gay plumage. His sage-green mantle, flaming crest, yellow back, and chequered tail-coverts have brought him into great request with the "plume" trade, which our gentle ladies, by their passire obedience to despotic milliners, so deplorably encourage. 'There are signs, however-welcome signs-that in proportion as they are beconing better informed of the nature and effects of this trade, so lady customers are showing discrimination and forbearance in the matter of hat and bonnet decoration. This is no more than might have been reasonably expected, for nobody believed that Englishwomen would consciously encourage cruelty.

Nen who understand country matters as a rule look favourably on Woodpeckers of all sorts at the present time. But it was not always so. A generation ago these beneficent birds were classed as rermin. There are few, if any, English manors where the register of game and vermin has been kept for so many years as at Lord Malmesbury's beautiful place, Heron Court, near Christchurch. There are some mouruful entries in the lists of vermin destroyed by the keepers on this estate during a single rear, 1852 - the only year of which I possess the record. Among them figure no less than fifty Woodpeckers, owing, no doubt, to the same groundless suspicion that caused the destruction during the same period of two hundred and fifty hedgehogs-namely, that they devoured the eggs of game. The hedgehog, alas! still figures in the black list of most gamelieepers, but few are so ignorant now as to molest the Yaffle.

Indeed, there is hardly any bird which by reason of its insatiable activity in the pursuit. of insects hurtful to vegetation better deserves protection at the hand of man; and let it not be forgotten that insects, taken as a whole, have been pronounced to be the most successful of all forms of life. As it is, they far outnumber all the land animals of the world, and it is only because one-half of this mighty host preys on the other half, and that the majority of birds, fish, and reptiles, as well as many beasts, live on them, that insects have not multiplied to the exclusion of all other animals from the globe. It is, therefore, no unimportant function that a purely insectivorous bird like the Woodpecker discharges in the scheme of nature.

Luckily, all the Woodpeckers are rery wary in their habits, seldom offering a chance to the mischievous hedge-popper, and requiring to be approached stealthily even by the friendly observer of their movements; so that in those parts of Great Britain where woodland has never completely disappeared they are still fairly plentiful. In Scotland it is otherwise. That country was entirely stripjed of its ancient forests, and with the forests disappeared much of the sylvan fauna. The Green Woodpecker is unkmown there, though there seems no reason why it should not be restored now that there are such extensive plantations. The Spotted Woodpeckers, being of more migratory habits, have made irregular appearances there of late years.

It is worth some trouble to watch the Yaffle at work upon a tree. Beginning at the root. it raps incessantly as it works up the stem, probably with the double purpose of disturbing any lurking insects and of detecting unsound wood, where fat grubs may be harboured. As soon as the game is afoot the tongue of the bird comes into play-a most serviceable instrument for the capture of creeping things. The tip is hormy and armed with a few bristles; the bone of the tongue is prolonged backwards 11 two branches, reaching round the back and orer the top of the shull, and meeting again in the cavity of the rirht nostril, where they are attached. Inside the bow thus formed runs a strip of muscle, which, when it is contracted, bends the bow and extrudes the tongue. Then, beneath each ear is a gland, discharging a glutinous secretion into the trough of the lower mandible, where the tongue lies when at rest, enabling the bird to pick up the smallest creeping thing.

Admirable as is the tongue of the Green Woodpecker, as an example of consummate adaptation of structure to requirements, it is by no means the only organ which has been modified to suit this bird's peculiar mode of getting a livelihood. The foot is what is known as "zygodactylic"-that is, arranged with two toes before and two behind, and the tail coverts 
are stiff, with sharp points, so as to act as a support in climbing. Then the breast-bone has been pared away in a remarkable manner, so as to clear the tree trunk in ascending, for the Yaffle never "climbs down"; when he gets as high in a tree as he thinks there is any need for, he either begins operations again at the base or flies off in a jerky, undulating way to another. I'be pectoral muscles are wanting in the depth and power necessary for a prolonged flight, which matters little to a bird like the Yaffle, of exclusively sylvan habits; though it is a mystery how some of the other species similarly specialized can undertake their regular annual migration in spite of this disability. Dr. Bowdler Sharpe has recorded how five young Great Spotted Woodpeckers were brought to him and Mr. Seebohm when in Heligoland. These birds had alighted in an exhausted state in a potato field.

The characteristic formation of the lreast-bone has been an advantage to the Yaffle in a way that can hardly have been foreseen when it was planned in nature's workshop. The resulting shallowness of the pectoral muscles-which render the breast almost devoid of flesh-is the reason why omnivorous man has never admitted the Green Woodpecker to his larder-or, at least, if he has done so, it is not recorded that he ever repeated the experiment. Even in France, where everything at all edible is turned to immediate use for the table, nobody has yet concocted a palatable dish of Piverts. Thus it comes to pass that, though one may travel in France for many days in Spring without hearing the gladsome note of blackbird, thrush, or lark, you cannot be long in a French woodland without being greeted by the Yaffle's well-known cry. It is as inseparably associated with the oak copse which represents the ancient forests of the Loire, as bunches of mistletoe are with the roadside poplars.

The affinity of birds and reptiles in the scheme of animated nature has been recognized Iong ago. The Green Woodpecker, besides its creeping habit, its extensile viscid tongue, and certain anatomical peculiarities in the bones of the head, possesses another attribute recalling the reptile lingdom. Its young are hatched as naked as young lizards, instead of being protected with down, like nearly all other nestlings. Perhaps, however, seeing that the nest is always in the heart of a tree, down has been dispensed with as a superfluity, unnecessary to young things so well protected against cold draughts.

The other two native species of IVoodpecker-the Great and the Lesser Spotted-are not less remarkable than the Yaffle for their gay coats; but they are less likely to attract attention, for, unlike their green cousin, they do not frequent anthills, they are not talkative, and they generally move among the higher branches of the forest. Black, barred with white, with sparks and streaks of scarlet, is the livery of the males of both Dendrocopus major and minor. The female also is started in life with a smart cap of red feathers; but, strange to say, when the young heus attain the age of six months all red disappears from their plumage, not by a moult, as Yarrell supposed, but by a change in the feathers from red to black. A similar change takes place in the young males; thefeathers of the fore part of the head remain scarlet till the first moult, which comes at the age of about ten months, when they are replaced with black. Simultaneously the back of the head and neck, hitherto black, becomes adorned with scarlet feathers, and remains so through life. No reason has been found for these changes; indeed the conspicuous colouration of the British Woodpeckers is very surprising and unaccountable, inasmuch as birds of similar haunts and habits, such as the Wryneck, TreeCreeper, and Nuthatch have the advantage of protective colouring, closely resembling the bark of trees which they frequent.

Woodpeckers, the Green as well as the two Spotted kinds, are still to be numbered among the avifauna of London, their appearance in Kensington Gardens having been noted several times in recent years.

Educational Series, $1 \frac{1}{2} \mathrm{~d}$. per 6 copies, post free. No. I.-OWLS. No. II.-WOODPECKERS. Others in course of preparation.

Pamphlets on the general question of Protection of Birds may also be obtained from the Society's Publishing Department, Knowledge Office, 326, High Holborn, W.C., or of Mrs. F. E. Lemon, Hon. Sec., Hillcrest, Redhill, Surrey.

Special terms for County Councils and Educutional Authoritics.

The Society's Publishing Oflice, hnowledge, 326, High Holborn, London, W.C. 1890. 


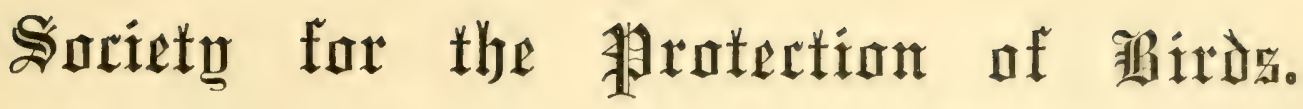

EDUCATIONAL SERIES. Edited by H. E. DRESSER, F.L S., F.Z.S.

\section{No. 3.-STARLING. \\ By O. V. APLIN, F.L.S.,}

Member of the British Ornithologists Union.

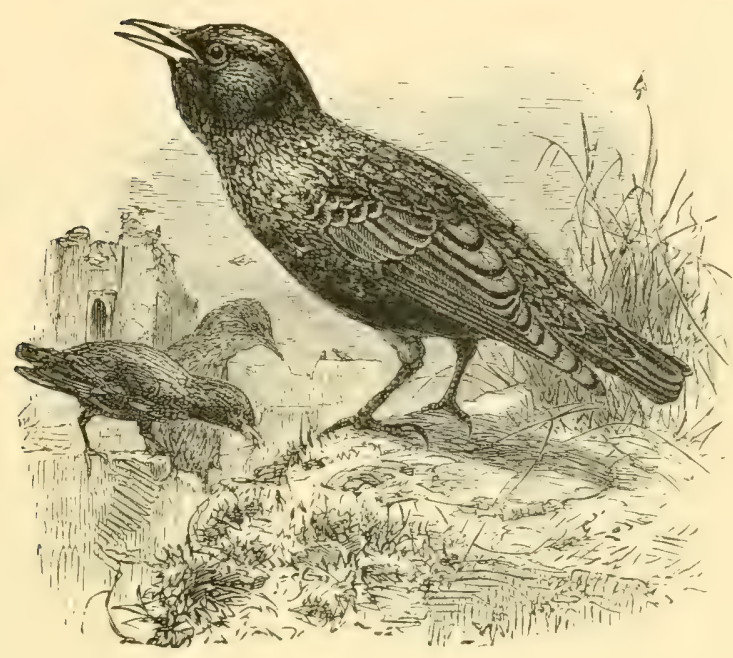

THE STARLING.

\section{Name.-STARLING.}

Family-Sturnidae.

Genus-Sturnus. Sturnus vulgaris. Starling.

\section{General Description.}

Adult male, in summer: black, but brilliantly shot with purple, green, and hlue; feathers of upper parts tipped with buffish-white; wing and tail quills gresish-black, slightly shot as above, and edged with pale brown; bill yellow. Length, 81 inches; wing, $5 !$ inches. Female: less bright and glossy, and more spotted. In winter : feathers of head and body have large dirty-white or buff tips; bill dusky. Young, on leaving nest, grecish-brown Illustration by Joseph Wolf, from "British Birds in their Haunts." B! kind permission of the societ! for Promoting Christian Knowledge, 
above and dirty-white beneath; bill dusky horn colour. In this plumage it is the "Solitary Thrush" of Montagu and Bewick.

\section{Where, when, and in what numbers found.}

An abundant resident, generally distributed over the British Isles; although it is only of late years that it has become common in some parts of Scotland, and has taken to breeding in some districts in Ireland. In autumn there is an immigration from Northern Europe, especially on our eastern coasts; and there is an internal westward migration.

\section{Food.}

Worms; grubs of the chafer, daddy-longlegs (crane fly), etc., etc.; small snails; slugs; insects, including grasshoppers, the "turnip fly" and other beetles, flies, and other winged insects; caterpillars affecting oak trees; and tieks; hedge berries, especially those of the elder and rowan. In winter some grain is eaten, but rarely. In some seasons (especially very dry ones), and in some districts, but not everywhere, a good deal of garden fruit, especially cherries; currants also are said to be eaten, and (in 1896) pears.

\section{Y. Characteristics.}

Hardly any bird is more easily encouraged to breed by the erection of small nesting boxes. Starlings may often be seen taking insects on the wing, and flying round almost like swallows for a considerable time. The Starling runs and walks on the ground with ease. It breeds in holes in trees, roofs, houses, towers, and ruins; in crevices and holes in rocky cliffs; in the heads of water-pipes; and, in the northern isles, in holes under stones, rat and rabbit holes, and holes in turf dykes, peat stacks, etc. The nest is made of straw, dry grass, and occasionally a few twigs, usually lined with some feathers, wool, or scraps of other material. Nesting goes on from the early part of April until the latter part of May. Eggs, from four to seven in number, uniform pale greenish-blue, about 1.2 in. in length and $85 \mathrm{in}$. in breadth. Single eggs are not uncommonly found deposited on the grass. Two broods are often reared by the same pair of birds. Young very noisy in nest; after leaving it they form flocks and resort to the grass fields and hedgerow trees. Song pleasing, and accompanied by a puffing up of feathers and shaking of wings; composed of chattering notes, snapling noises made by beak, and long, sweet whistles. Mimics notes of other birds. Very loquacious, and call and alarm notes very varied; e.g., "stare" or "starr," "spatt," a whistle, and a metallic "tink" or "quink."

\section{Protection.}

Wild Birds Protection Act, 1880.-This bird does not appear in the schedule, but anyone other than the owner or occupier of land, or his agent, taking, killing, etc., a Starling 
during close season,* or possessing or selling a Starling after 15th March, is liable to at penalty of $5 \mathrm{~s}$. for each bird.

Wild Birds Protection Act, 1894.-The eggs are protected (1896) in the following counties:-

England :-Metropolitan Police District, mcluding London and Middlesex; in the breeding areas in Northumberland, York (East Riding), Cambridge, Chester, Norfoll, East Suffolk, Devon, Essex, Kent, and Isle of Wight.

Scotland :-Orkney.

Wild Birds Protection Act, 1896. - In addition to any penalty under the Act of 1880, the Court may now order any trap, net, snare, ete., used by the offender to be forfeited.

The Starling is protected throughout the whole year in the county of Middlesex.

\section{Remarks.}

The Starling is one of those birds which are pre-eminently fit to survive. It is wary enough to take care of itself, without being at all shy, that is to say, it does not in the least mind the company of human being's, provided they do not molest it. Indeed, with this proviso, it rather prefers to settle down as man's near neighbour, beciuse his cultivater ground, his grazing land where eattle are lept, and his gardens, are always rich in worms and insects, while his buildings afford almirable nesting quarters. Now this tolerance of the presence of the human race is a very important factor in deciding the comparative abundance or scarcity of any bird in England. For in a thickly-populated country, if a bird cannot bear to be near human beings, and to see a good deal of them-well, it must go somewhere else, and it goes, Birds differ in this respect in at very curious way.

The Starling is also a bold, pushing, persistent bird, of a roving disposition, able and willing to adapt itself to new surrounding's, given to coreting and talking possession of its neighbour's house, and eminently well fitted for staking out new claims for itself and its posterity. It is, in a word, a good colonist. In addition to this the Starling can feed himself easily, being able on occasions to dispose of a tolerably varied bill of fare. In winter the birds assemble in flocks. Together they hunt for food, and together they roost in some wood, shrubbery, or great reed or rush bed. It is probable that they range far and wide for food in the winter, for big roosting-places are fer and far between, and it is a common sight late on a wiuter's afternoon, to see flock after flock travellng rapidly in the same direction. It is a fact worth remarking upon that the stirling gets up rather late in the morning - a sufficient proof that it talies care of itself, and that the early worm, to this great hunter of worms, is no better and more desirable than one pieked up in il mell-aired world. Most people must have noticed the winter habit of the flockis of starlings of consorting with flocks of Rooks. It has not been satisfactorily explained which, if either,

* Generally from 1st March to 31st July, but in some counties from 1st February to 31st August. A further period may be obtained through the Act of 1896 , as in Middlesex. 
party, profits by this arrangement. Rooks are keen enough in finding their own food, and it is more probable that the Starling profits by their companions' large beaks and greater powers of breaking the ground. We can imagine, too, an active Starling (no bird is more active on its feet) cutting in and picking up some morsel unearthed by the stronger and more powerful, yet slower, Rook. Perhaps the Starling profits by the rigilant outlook kept by the sentinel Rooks. In the case of an alarm to the mixed host, it is amusing to see how quickly the Starlings are up; the partnership is dissolved in a moment, and with manœurres, executed with greater quickiness and precision than any troops can attain to, their ranks close up, and a compact phalanx wheels out, leaving the disorderly ranks of its confused allies to get under weigh as best they can. I must not write here of the Starling's manner of feeding, its beautiful aerial manœuvres, its wonderful wheeling and turning, to be witnessed on a winter's erening at one of its great roosting-places, and of the vast number's which collect at such roosting-places. Its covering of feathers fits closely to its body, the feathers themselves being glossy and rather hard, so that the plumage is not easily draggled, and is very weather proof.

Finally, the Starling has a wandering and migratory habit, and when other birds are starving in hard weather the Starling departs for some more genial and hospitable locality. It is true that some, even a good many, perish in severe winters, but I have always noticed that the great flocks, which we generally have in my own neighbourhood in mild winters, disappear in hard weather, to reappear alnost immediately a thaw sets in. The Starling often visits low-lying sea shores in winter, where between high and low water mark food is always to be obtained.

It is not then surprising to find that the Starling is steadily increasing in numbers, and that during the last half century or so it has increased its range in Great Britain.

This great increase in the Starlings' numbers is being watched by ornithologists with interest; for it has given rise to two great questions anent the future history of this bird and others. The first is, what effect will the increased Starlings have on the increase of some other birds? When Starlings take up their summer quarters in a wood, or in some locality where trees are abundant but buildings scarce, there is a run on any convenient hole in a tree. A Starling will build in almost any hole, if it is not too large, but some birds, e.g., Woodpeckers and the Nuthatch, are more particular. The Starling is not content to take only the deserted or vacant holes, to which it would be welcome, but when a Woodpecker has chipped out a new hole or enlarged an old one, or when a nuthatch has carefully plastered up the gaping mouth of some hole so as to adapt it as a residence for itself, these industrious and not too common birds are only too likely to be ousted by a pair of noisy Starlings. T'he fight for a hole lists often all day long, and the Starling wins, as other greater fights have been won, by wearing out its adversaries. Time after time the rightful owners dash at the intruders, who, not being furnished with a very business-like fighting beak, beat a hasty retreat, only to return almost immediately and continue their annoying harsh cries and demonstrations. Indeed, the Starlings' business is not to fight, but to tire the owners out and cause them to give up the lole in disgust. The Starlings bring bits of building materials with them, and, presently, when both of the exasperited owners have dished after 
one Starling, the other slips into the hole. Perhaps he remains at the entrance srearing and screaming, but even if he comes out again he has deposited a long straw or some such material in the nest. No Nuthatch would put up with the untidy furniture a Starling uses, and the Woodpecker positively hates any such trash, having what I once heard a purveyor of household goods call a very severe taste in the matter of furniture. So the Woodpeckers and Nuthatches have to go elsewhere, and where Starlings are very abundant in woods and woodland districts, I have no doubt that they are already somewhat detrimental to the existence of the birds just referred to.

The second great question is, how are these increasing hosts going to feed themselves in the future? Will they alter their mode of life? The Starling at present has a curious character in respect of its food. On the whole it may be said to be an extremely beneficial bird; this is true of the bird over the whole country. In some districts it may be said that it never does any harm, in others that it is practically harmless; but, unfortunately, in some districts the Starling does, undoubtedly, very considerable damage to cherry growers. The charge of eating cherries, and of feeding its young with them, was made over fifty years ago; it has been repeated and proved over and over again, and yet, even to-day, the labit is not universal in all districts, nor is it constant in some others. In my own district, only one instance of serious cherry robbery has come under my notice, and only a few weeks ago a correspondent of the Field newspaper wrote, from a district where the orchards were well stocked with fruit, including cherries, to say that he had never seen a Starling attack a fruit tree of any description. Lord Lilford wrote that in Northamptonshire he never heard any gardener speak of the Starling as an enemy. The Starling has been clarged with destroying the eggs of Pigeons and other birds, but the charge has not been siatisfactorily proved. Apart from cherry eating, and very occasional offences in eating currants, pears, and other garden fruit, no bird does more good in respect of the food which it eats. And the result of even a rather prejudiced and very incomplete investigation into the food of some of our birds recently carried out, was that the Starling was declared to be a beneficial bird. It rids the pasture fields of noxious grubs and insects, the sheep of ticks, and the trees of caterpillars. Instances have been known of its clearing turnip, fields attacked hy "fly," and I hare known it visit a field of peas affected by aphides, with good results. The good it does in these ways would be sufficient to make up for far graver faults than those which hare been laid to its charge.

\section{Educational Series. -3 copies, 1d.; 1 dozen, 3d. ; 100, 1s. 6d., post free.}

Pamphlets on the general question of Protection of Birds may also be obtained from the Society's Publishing Department, Knowledge Oflice, 326, High Hulhorn, W.C.; or of Mrs. F. E. Limor, IIon. Sec, Hillerest, Redhill, Surrey. 


\section{Soriety for the 稀rotertion af birts.}

\section{EDUCATIONAL SERIES.}

No. I.-OWLS, by Montagu Sharpe, J.P., D.L.

No. 2.-WOODPECKERS, by Sir Herbert Maxiveld, Bart., M.P.

No. 3.-STARLING, by O. V. Aplin, F.L.S., M.B.O.U.

No. 4.-SWALLOWS, by Thomas Southwell, F.Z.S.

No. 5.-KINGFISHER, by Sir EdWARd Grey, Bart., M.P.

No. 6.-OSPREY, by J. A. Harvie-Brown, F.R.S.E., F.Z.S.

No. 7-DipPeRS, by W. Lock Mellersh, B.A.

No. 8. - NightJAR, by Montagu Sharpe, J.P., D.L.

No. 9. - TITMICE, by Sydney Buxton, $M_{n} P$.

No. Io.-KESTREL, by Rev. J. E. Kelsall, M.A.

No. i i.-PLOVERS, by Joseph A. Pease, M.P.

\section{IN COURSE OF PREPARATION.}

No. - - TERINS, by Thomas Southwell, F.Z.S:

No. - Whatails, by W. Warde Fowler.

No. -ChOUGH, by J. A. Harvie-Brown, F.R.S.E., F.Z.S.

No. -GOLDFINCH, by W. H. Hudson, C.M.Z.S.

No. .JAY, by John Cordeaux, M.B.O.U.

No. .-GULLS, by Howard Saunders, F.L.S., F.Z.S.

No. - - by Wm. Eagle Clarke, F.L.S., etc,

No. .-SKUAS, by T. E. BuckLey, M.A., F.Z.S.

And Wild Birds Protection Acts and Orders, I880 to I396, with Explanatory Notes. by F. E. Lemon, M.A., LL.B.

Copies of the above Series may be obtained from the Society's Publishing Department, "Knowledge" Office, 326, High Holborn, W.C., or from the HoN. SEc., Mrs. F. E. Lemon, Hillerest, Redhill, on the following Terms:-Post Free: 3 Copies of any one number of the Series, 1d.; I Dozen, 3d.; 100, 1s. 6d. Assorted Packets: I Copy of any six numbers, 2d. ; I Copy of any twelve, or 2 Copies of any six numbers, $4 \mathrm{~d}$.; or fifty Assorted numbers, $1 \mathrm{~s}$.

Special Terms for Larger Quantitics, and to County Conncils, the Constabulary, Schoois, and Educational Bodies. 


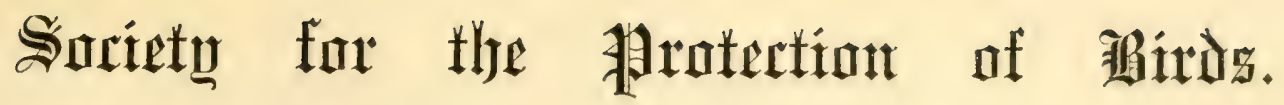

EDUCATIONAL SERIES. Edited by H. E. DRESSER, F.L.S., F.Z.S.

\author{
No. 4. -SWALLOWS. \\ By ThOMAS SOUTHWELL, F.Z.S.
}

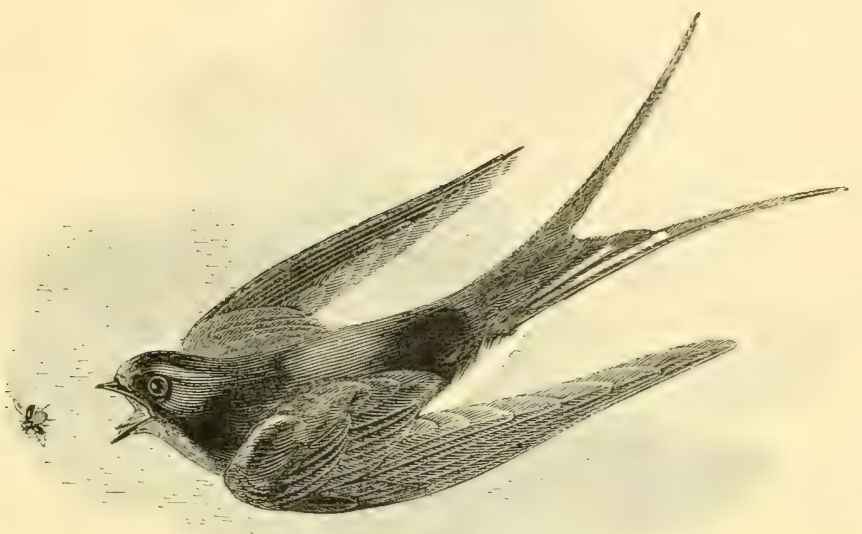

\section{Name.-SWALLOW.}

Family-Hirnondinide.
Genus-1. Hirundo.
"2. Chelidon.
"3. Cotile.
Hirundo rustica.
The Swallow.
C. urbica.
C. riparia.
House Martin.
Sand Martin.

\section{General Description.}

The Swaliom.-Adult, male: Forehead chestnut; all the upper parts shining steel blue; wing and tail-quills black glossed with bluish-green, the middle tail feathers wholly so, the others with the inner web more or less patched with white; chin and throat chestnut, followed by a broad band of black, glossed with steel blue; rest of the lower surface warm buffy white (deepest about the vent); legs, toes and (liaws black. Female: Colours not so pronounced. Length, $8 \frac{1}{2}$ in., outermost tail feathers nearly 5 in.; shorter in the female, and the full length not acquired by the young until after the first moult.

The House Martin.-Adult in both sexes: Upper parts glossy bluish-black; r ruml'

Illustrations on pages 1, 4, and 6, from "Manual of British Birds," by Mr. Howard Saunders, by kind permission of Messrs. Gurney \& Jackson. 
white; wings and tail-quills dull black; chin, lower parts, and feathers on legs, white. Young birds sooty-brown above, little gloss, and not so pure white beneath. Length about $5 \frac{1}{4}$ in. Tail in the young birds less forked.

The Sand Martin.-Adult, male: Upper part nearly miform mouse colour, palest on the rump; wings and tail blackish-brown; under parts white except a mousecoloured pectoral band (this latter rather narrower in the female). Birds of the year have the feathers of the upper parts tipped with dull white, and under parts tinged with buff. Length about $4 \frac{3}{4} \mathrm{in}$.

\section{Where, when, and in what Numbers found.}

All three species are common summer migrants to our shores, the Sand Martin usually arriving first about the end of March, shortly to be followet hy the Swallow, and about the same time by the Honse Martin, and retreating in the same order. The Swallow is generally distributed, decreasing in numbers as the North is approarhed, but visiting the Hebrides and even oceasionally Orkney and the Shetlands. The Honse Martin also visits the latter Islands, hut is unknown in the Hehrides. The Sand Martin is also widely diffused in suitable localities throughout the British Isles, but from its habits is somewhat more loral.

\section{IY. Food.}

All three species subsist entirely on insects, and render incalculable service by the enormous numbers of these pests which they destroy.

\section{Characteristics.}

The Swallows are characterised by their almost ceaseless flight, which is proverbially rapid and graceful, and is continued from early dawn till dusk. The two first-named species select as their home the neighbourhood of human dwellings, especially preferring those in the vicinity of water, and although from the nature of its nesting-site the Sand Martin is less the companion of man, this does not appear to arise from choior. Their nesting hathits, which are interesting, will be briefly alluded to in Section VII.

\section{Protection.}

Wild Birds Protection Act of 1880.-These birds do not alprear in the Scheluli. but (1896) have been added to it in the following Counties :-

FNaLAn D:-Durham; Lancaster; Buckingham; Huntingdon (Swallows only); Leicester;

Lincoln (Kesteren and Lindsey); Stafford; West Suffolk; Worcester; Kent; Metropolitan Police District, including London and Middlesex; Isle of Wight; Wilts.

WATES :--Brecon.

In these Counties any owner or occupier, or other person, taking, killing, etc., any of these birds during close season,* or possessing or selliug one of them after 15 th March, is liable to a penalty of $\& 1$ for each bird.

Wild Birds Protection Act of 1894.-Their eggs are protected in the following Countiest:-

* Generally from 1st March to 31st July; but in some counties from 1st February to 31 st August in each year. A further period may be obtained through the Act of 1896.

+ It is expected that other counties will before long obtain similar orders of protection under the Act of 18.94 . 
ENGLAXD :-Durham; specified areas in Northumbertand and York (East Rirling); -Leicester; Lincoln (Kesteven and Lindsey); West Suffoll; Worcester; specified areas in Cambridge, Chester, Norfolk and East Suffolk;-Kent; Metropolitan Police District, including London and Middlesex; specified areas in Deron and Isle of Wight.

Scothaxd :-Orkney (Swallow and House Martin).

In the above places, any owner or occupier, or other person, taking or destroying the exgss of these birds is liable to a penalty of $£ 1$ for each egg.

Wild Birds Protection Act, 1896. - In addition to any penalty under the Act of 1880, the Court may now order any trap, net, snare, etc., used by the offender to be forteited.

These birds are protected throughout the whole year in the County of Middlesex.

\section{Remarks.}

1. The Swallow.-True it is that one swallow does not make a summer, and this charming bird which comes to us with the promise of sunny skies and opening Howers, frequently falls a victim to its misplaced confidence in the changing climate of our inhospitable springs.

While yet "the trembling year is unconirm'd," and winter oft resumes, the breeze "chills the pale morn and bids his driving sleets deform the day delightless," the early arrivals of these birds suffer sreatly; it is piteous to see them shimming wearily orer the water or under the shelter of a wall or fence, too often only to fall vietims to cold and starvation. But when wilrm sumn weather las at list taken the place of fitful spring, and insect life has responded to its genial influence, what a thing of beaty is this charming bird as it pursues its rapid flight, turning aud doubling in the chase of its active prey, or sits sumning itself on some chimney or gable, softly warbling its pretty song; or it may be on the margin of the village pond, collecting the moist soil which is to furm the foundation of its nest!

Hunting over the grass, in and out amongst the cattle, or under the eares of houses, this suciable little bird is seldon seen far from the haunts of man, and when its nesting site is chosen, it is either the large open chimney of some humble cottage, the rustic porch, or the rafters of the eattle shed or barn. Its whole existence seems to be a delight, and it is absolutely fearless of man, ats though conscions of the benefits it confer's inon him. Not much time is wasted after its arrival before the cares of houselieeping begin to oceupy its little breast, and the old nest is insprected and repaired, or if need be an new one constructed. This is in silucer-shaped structure built of clay, interwoven with grass or stritw and warmly lined with feathers; and herein it deposits its five or six lovely trinslucent white egers, prettily spotted with orange-brown and grey. These in due time are hatched, and early and late the parent birds may be seen hurrying to and fro feeding their humgry soun: ones. No prettier sight than watching this labour of love ean be imagrined, and the writer recalls a nest attached to the rafters of a summer-house where the parents passed in and 
out in close proximity to him, delivering their welcome burlens to their precious young ones, whose little chins projected beyond the edge of the nest, while their bright eyes looked down fearlessly on the strauger beneath them. The first brood disposed of, the old birds rest not, but renew their labours at once, and should circumstances fitrour, a second brood follows their elder brethren, and ranges itsulf alungside of them on the roof, tree, or telegraph wires, survering the busy world below, and perhaps dreaming of the aproroaching flight southward for which their parents have been preparing them.

Migratory jarties now soon commence taking their departure, and are in due time followed by the late broods and old birds, and by the end of October only an occasional belated bird is to be seen, although there are records of much later occurrences. In the choice of a nesting place, as has been said, this bird frequently evinces considerable eccentricity, often choosing situations where it has to come into very close contact with man or other disturbing influences; many such instances have been recorded, but space will only allow me to add one other to the list. In the year 1894, a grentleman residing at. Corton, near Lowestoft, informed me that a swallow had made a ne'st amongst the machinery of a wind flour-mill. It entered by the hole through which the sbaft bearing the mill sails passed, and had to "dodge" the revolving sails every time it eame and went, the mill being in daily use. The nest itself was built on the underside of a large wheel known as the "wallower," and was constantly revolving with this wheel. It was estimated that the nest and sitting bird travelled in a circle at the rate of about $180 \mathrm{ft}$. per minute, the bird going tail foremost. Here, in almost constant motion, and amongst the creaking and shaking of the machinery, the bird hatched and carried off its young ones in perfect safety.

2. The House Martin.- Hr. Stevenson, in his charming account of this bird in the "Birds of Norfolk," truly says a small book might be written on the habits of this



HOUSE MARTIX. "universal favourite" without exhausting the subject, and I, alas, have little more than a page to devote to it.

Myths die hard, and it took a long time to slay the myth of hybernation of the Swallow tribe, but we think there are not many living now who expect to find swallows and martins clustered together in holes in the ground, hollow trees, or in the mud at the bottom of the village pond when Nature is fast bound in winter's frosty fetters. Belated Martins there occasionally are, but even these if they do not succumb to cold and want of food eventually follow their brethren to warmer climes, there to await the return of the season of reproduction which irresistibly recalls them to their true home. 
'The 18th of April will generally be marked by the appearance of the Martin if it is not in eridence a day or two earlier, but, alas, it visits us in far smaller numbers than formerly.

No sooner does the weather become genial than the birels visit their wh nests, returning season after season to the same spot with the greatest resularity and pertinateit and at once commence the necessary repairs or reconstruction. Though by nature a cliff builder, the Martin for the most part, selects the sheltering eave of a dwelling-house, frequently in busy towns, for its nesting site, and there it constructs of mud and straw its semi-spherical abode, the back and perhaps the top being formed by the wall and eares of the house, and only a small hole being left for ingress and egress. As the bird is very sociable in its habits, several nests are often erected round the same house, and occasionally quite a row of these singular habitations are scen side by side. Occasionally, I fear too often, the labour is all in vain, and, when complete, the nest is taken possession of by the marauding sparrow ; the decrease of Martins of late year's is attributed hy some partly to this cause. It is interesting to see these elegant birds collectiug mud to form their nests from any damp place by the wasside, and in continued droughts they will follow the watercarts, collecting the moistened soil from the little pools left on the roulds. Both birds worli at the structure, to which they cling in succession by claws and tail, each one in turn lating its little brick; a few dried grasses and a warm lining of feathers complete the structure. The eggs are pure translucent white, and number four or five.

In the evening "The sitting bird leaves her nest for a while to stretch her weary limbs and join with her mate the twittering throng. Now, mingling in full chorus, they swatrm over our heads; now, separating in all directions, they slim over the trees and housetops, rising and filling under the eares of our dwellings; and, again collecting, repent their vatried movements, till, almost impereeptibly, when the sum has set and the deepening sbadows are stealing orer the seene, they drop off by degrees to their respective homes, and the stillness of the summer night succeeds in strange contrast to their busy actions." *

When the young are hatched, the quantity of noxious insects destroyed hy these useful birds, large at all times, is immensely increased. Macgilliviay, who was an cxellent observer, states that in the middle of July a pair of these birds visited their young one's with food three hundred and seven times in one day, between the hours of four a.m. ind eight p.m., waking at certain parts of the day twenty-eight visits per hour, and as they rear two bromls, the services each pair render must be inestimable.

As the season advances the young birds congregate and talie their departure, leaving the old ones and the late broods to follow. Not unfrequently the late brovis are found dead in the nest; whether they have been deserted by their parents, whose migratory impulse has been too strong to allow them to remain, or whether they have perished from scarcity of food is uncertain, but I am inclined to adopt the latter belief, and liy the middle of October the resident birds have, as a rule, disappeared. But even then we have: not seen the last of the Martins, for during November and even into December, should the season be open, flocks of passing migrants on their waty from still mure nortberly

* "Birds of Norfolk." Vol. I., page 33ũ. 
localities to their winter quarters put in an appearance, but soon they pass on and are no more seen till spring comes agail.

3. The Sand Martin.-Yet one more member of this interesting family is a regular visitor to our land, and this is the earliest to arrive, frequently putting in an appearance towards the end of March, when it is generally recorted hy not very observant people as the "Swallow," which bird, however, does not reach us till some time later. The active little Sand Martin is in no hurry to commence the duties of maternity, and for some weeks it may be seen busily hunting for insects showing great partiality for water. Its flight differs from that of the two preceding speries; although expally rippid, it is distinguished by a peculiar jerling motion, which is ahmirably described by Macgillivray as follows :- "There comes at Bank Martin, skimming along the surface of the brook, gliding from side to side, deviating by starts, now sweeping over the bank, wheeling across the road, making an excursion over

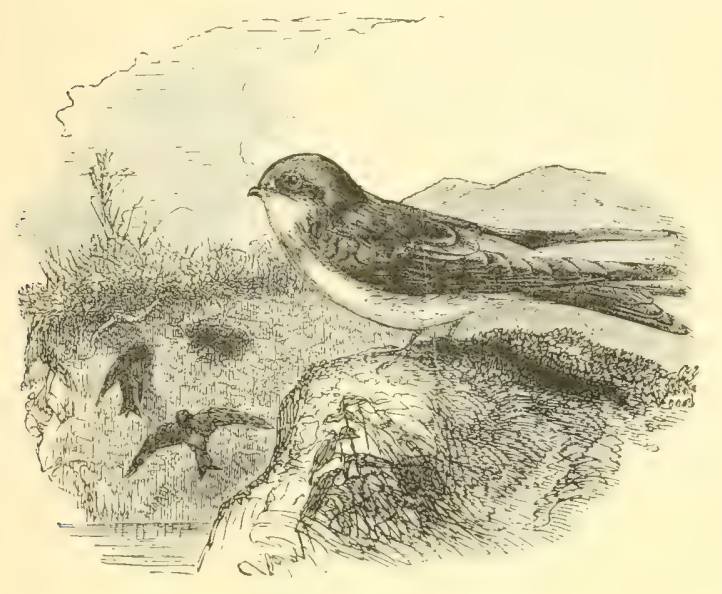

SAND MARTIX. the cornfield, then rising perpendicularly, slanting away down the wind, fluttering among the spikes of the long grass, and shooting off into the midst of a multitude of its fellows." Mr. Stevenson, who quotes this passage in his "Birds of Norfolk," adds, "Almost as one reads this graphic passage, low hurried twitterings seem to fall upon the ear, and he who in his mind's eye cannot see that Martin is no true lover of Nature."

When the time does arrive for these gay little birds to turn their attention to more serious matters, unlike the two other members of the family, they repair to some railway cutting, a sand or chalk pit, or other suitable locality, and there congregating, often in rery large numbers. they form for themselves little burrows in the face of the cliff, from two to three or even more feet deep, in the friable soil, at the far end of which the nest is placed, and here are deposited, on a collection of roots or grass, lined with feathers, the five or sis pure white eggs. These nest-holes are sometimes very numerous and in close proximity, and the labour incurred in excavating them must be immense; probably the same hole is occupied year after year by the same pair of birds, and it occasionally happens that a Kingfisher takes possession of one of the burrows, which it slightly enlarges for its own purposts. Some gears ago, the writer saw a colony of "Sand" Martins which had talien possession of a large he'al" of sawdust, consolidated by time, and in the face of which they had driven their galleries.

It is a pretty sight to watch these little mouse-like birds going to and from their nests in perpetual streams, returning with unerring precision each one to its own burrow, at the entrance of which it alights and immediately disappears into the depths. When the 
young ones appear the multitude of birds hawking in the neighbourhood is greatly increased.

The end of August finds the numbers of Sand Martins considerahly (lecreased, but they still frequent their old haunts, flying in large quantities over the meadows and rivers, and clustering on the reeds and telegraph wires in crowds. Flight after flight, howerel, take their departure, till by the end of Septemher Sand Martins are rare birds in the land, ant they have all returned to the sunny African clime from which they came to us in the spring.

There is one other member of the sime family, the Purple Nartin of the American continent, a single example of which has been found in Ireland; but this, although a rery interesting species, does not concern us here. The Swifts, too, although popularly associated with the Swallows, belong to an entirely distinct family (Cypselidir), their nearest allies heing the Humming-Birds (Trochilidie).

And now if I have succeeder in interesting my readers in these charming birds, which are fraught with such pleasant associations, and whose hahits are so attractive, may I "arnestly beg that never again will they desecrate their remains by applying them to purposes of personal adormment-many thousands are lilled, we are told, on their anmal migrations to supply the demands of the "plume trade," as offerings to that inexorable" demon, fashion. How long will our wives and sisters turn a deaf ear to the pleadings of this and kindred societies on behalf of these and other lovely creatures, and for the salie of a passing whim compass their utter destruction? Will neither their beauty nor their utility save them from annihilation? and must the common right of all in the beautiful creations with which God has adorned the earth be sacrificed to the vanity and thoughtlessness of the few?

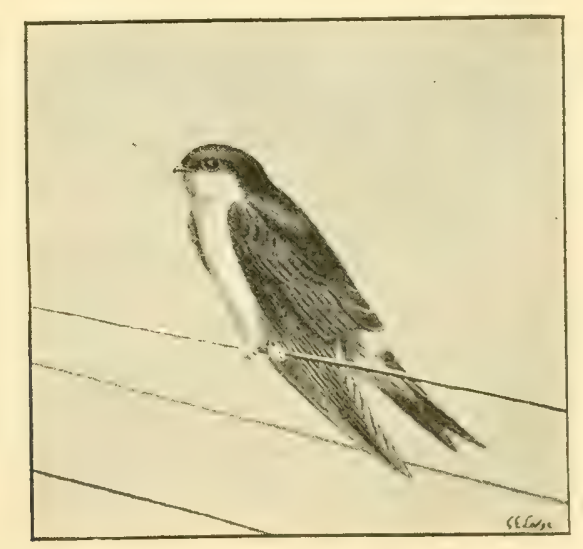

Illustration from "British Birds," hy W. H. IIutson, by kind permission of Messrs. Longmans, Green \& Co.

Educational Series, 3 copies, $1 \mathrm{~d} ; 1$ dozen, $3 d$; $100,1 \mathrm{~s} .6 \mathrm{~d}$., post free.

Pamphlets on the general question of Protection of liris may also be obtained from the Sociuty's Publishing Department, Knowledge Oflice, 326, High ITolhorn, W.C., or of Mrs. F. L. T.mox. Ion Sere, Hillerest, Redhill, Surrey.

Special terms for County Councils and Educational Authorities. 


\section{Soriety for the 羽rotertion of Birts.}

\section{EDUCATIONAL SERIES.}

No. I.-OWLS, by Montagu Sharpe, J.P., D.L.

No. 2.-W00DPeCKers, by Sir Herbert Maxweld, Bart., M.P.

No. 3.-STARLing, by O. V. Aplin, F.L.S., M.B.O.U.

No. 4.-SWALlOWS, by Thomas Southwell, F.Z.S.

No. 5.-KINGFisher, by Sir Edward Grey, Bart., M.P.

No. 6.-OSPREY, by J. A. Harvie-Brown, F.R.S.E., F.Z.S.

No. 7-DipPeRS, by W. Lock Mellersh, B.A.

No. 8. - NightJaR, by Montagu Sharpe, J.P., D.L.

No. 9.-TItMice, by Sydney Buxton, M.P.

No. io.-KeSTREL, by Rev. J. E. Kelsall, M.A.

No. i i.-PLOVers, by Joseph A. Pease, M.P.

\section{IN COURSE OF PREPARATION.}

No. . - TeRNS, by Thomas Southwell, F.Z S.

No. - Wagtails, by W. Warde Fowler.

No. -ChOUGH, by J. A. Harvie-Brown, F.R.S.E., F.Z.S.

No. -GOLDFINCH, by W. H. Hudson, C.M.Z.S.

No. - - JAY, by John Cordeaux, M.B.O.U.

No. -GULLS, by Howard Saunders, F.L.S., F.Z.S.

No. - - by Wr. Eagle Clarke, F.L.S., etc,

No. .-SKUAS, by T. E. Buckley, M.A., F.Z.S.

And Wild Birds Protection Acts and Orders, ISSo to IS96, with Explanatory Notes, by F. E. Lenon, M.A., LL.B.

Copies of the above Series may be obtained from the Society's Publishing Department, "Knowledge" Office, 326, High Holborn, W.C., or from the HoN. SEc., Mrs. F. E. Lemon, Hillcrest, Redhill, on the following Terms:-Post Free: 3 Copies of any one number of the Series, 1d.; I Dozen, 3d.; Ioo, 1s. 6d. Assorted Packets: I Copy of any six numbers, 2d. ; 1 Copy of any twelve, or 2 Copies of any six numbers, $4 \mathrm{~d}$.; or fifty Assorted numbers, $1 \mathrm{~s}$.

Speciul Terms for Larger Quantities, and to County Councils, the Constabulary, Schools, and Educational Bodies.

JANUARY, 1897 . 


\section{Sinciety far the Mrotertion af allitù. \\ EDUCATIONAL SERIES. Edited by H. E. DRESSER, F.L.S., F.Z.S.}

\section{No. 5.-KINGFISHER.}

By SIR EDWARD GREY, Bart., M.P.

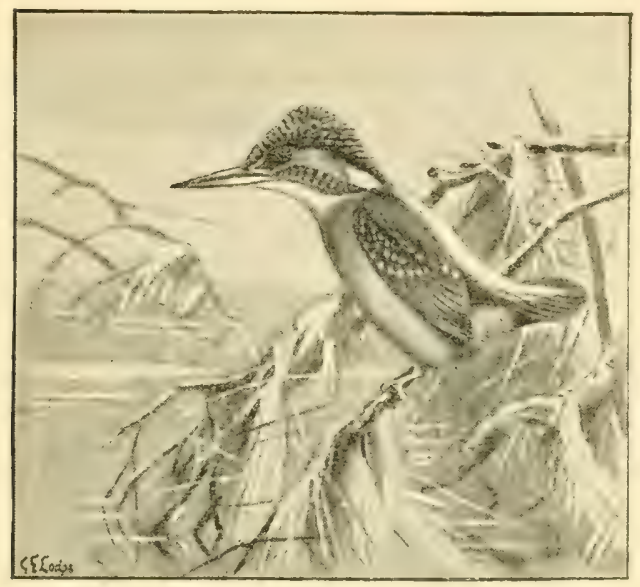

KINGFISHER.

\section{Name,-KINGFISHER.}

Family-Alcedinidr.

Genus-Alcedo. Alcedo ispida. Kingfisher.

\section{General Description.}

Adult male: Head, wings, and moustacbe, dark greenish hlue, slightly mottled with dirty white; back, azure blue with a faint greenish tinge; tail, dark blue; throit, white; lower ear coverts and under parts chestnut; bill, orange on the hasal part, but otherwise blackish; feet reddish brown. Total length, 7 inches; wing, 3 inches. Female: Somewhat duller and greener in tone of colour than the male. Young: Resembles the female, but is even duller in tone of colour, and the bill is entirely black

\section{Where, when, and in what numbers found.}

The Kingtisher is resident and very generally distributerl throughout England and Scotland, but becomes rarer in the northern part of the latter country, and is found also iu Illustration by kind permission of Messrs. Longmans, Green, \& Co., from "British Birds," by
Mr. W. H. Hudson. 
Ireland, but chiefly in the lowland districts. Owing to the persecution it has suffered, its hright plumage being greatly sought after both for decorative purposes and for the making of artificial flies, it has greatly decreased in numbers of later years, and it is one of our birds that especially needs and deserves protection.

\section{Food.}

Small fry of various kinds of fish, minnows, sticklebacks, ete, dragon-flies, water beetles, and aquatic insects of various kinds.

\section{Characteristics.}

In general habits it is somewhat solitary, a single pair frequenting the stream or the portion of the stream where they hare taken up their quarters, and they evidently resent the intrusion of others on their domain. They frequent streams, brooks, and rivers-especially where the hanks are wooded and the current is not too rapid-ponds, lakes, and even the seashore. The flight of this bird is direct and rery swift, performed with rery quick heats of the wings. It will sit for long on a branch or any other suitable perch over the water, and when a small fish passes. will plunge suddenly in the water, rarely missing its prey. It deposits its eggs-which are glossy white, rounlish in form, five to seren in number, and measuring 0.75 by 0.57 in size-on the small fish bones and exuviæe cast up by the birds, at the (nd of a hole in a bank, which is generally about four feet long, narrower at the entrance, and widened considerably at the end which forms the nest chamber.

\section{Protection.}

Wild Birds Act, 1880. - This bird appears in the Schedule, which applies to every County in England, Scotland, and Irelant. Any owner, oceupier, or other person taking, killing, etc., a Kingfisher during close season, * or prsessing or selling a Kingfisher after 15th March, is liable to a penalty of $\mathfrak{E L}$ for each bird.

Wild Birds Act, 1894. - The eggs are proterted at present (1896) in the following Counties, or specified breeding areas in Counties : $\nmid$ -

England :-I. Cumberland; Durham; Northumberland; Westmoreland; Yorlis, E. Riding; specified breeding area. Promontory of Spurn, including Kilnsea Warren. II. Bedford, Cambridge; specified breeding area, WVicken Sedge Fen ; Chester' specified breeding area, Hundred of Wirrall; Derby; Gloucester; Huntingdon; Leicester ; Lincoln; Kesteven and Lindsey; Norfolk; specified breeding areas; Northampton; Stafford; Warwick; East Suffolk; specified breeding area; West Suffolk; Worcester. III. Devon; Hertford; Isle of Wight; Kent; Metropolitan Police District (including London, and Middlesex), Southampton.

Wales:-Brecon; Glamorgan; Pembroke.

Scothand :-Berwick; Dumfries; Elgin ; Haddington; Kirkcudbright; Wigtown.

* Generally from 1st March to 31st July; but in some counties from 1st February to 31st August in each year. A further perio $d$ may be obtained through the Act of 1896 , as in Middlesex.

+ It is expected that other counties will before long obtain similar orders of protection under the Act of 1894 . 
IRELAND :-Roscommon.

Any owner, occupier, or other person taking or destroying a Kingfisher's eggs, penalty $£ 1$ for each egg.

Wild Birds Act, 1896.-In addition to any penalty under the Act of 1880 the Conrt may now order any trap, net, snare, ete., used by the offender to be forfeited.

This bird is protected throughout the whole year in the County of Middlesex.

\section{Remarks.}

All birds have some more or less distinct peculiarities of plumage, roice, manner, or hitbit, by which, if we ohserve them closely, we come to know them well. It is for the brilliancy of its plumage that the Kingfisher is renowned. Many British hirds have heautiful colours. Int not one of them has plumage which is so bright as the Kingfisher's, and which flashes so as the bird flies through the air. We have plenty of common birds of all sizes, from the cock pheasant to the tomtit, which look gay enough if we see them near and still, and yet we do not see their colours lurightly as they fly; but the Kingfisher's plumage is so bright that the bird looks brilliant eren as it passes on the wing, and, though its flight is swift, the very speen of it seems to make the colour flash the more.

It is unreasonable enough that a bird which is so beautiful as it flies should be most often killed because of its beauty, but this is no doubt one cause why Kingfishers are so) comparatively seldom seen. Any day and any walk is more interesting and more happy for having seen a Kingfisher, and if men were wise this should huve led to the preservation of the birds. It has, on the contrary, hitherto led to their destruction. Meyer says of the plumage: "The Kingfisher surpasses all other British birls in the brilliancy and rbangeable. ness of its colouring, which varies with every change of position, from the most brilliant turquoise blue to the warmest green in the lighter parts of its plumage, and in the darker reflecting copper and gold. . . . . When dead and preserved for a cabinet its plumage has a dull bluish or muddy-green appearance, and the brilliant tints of life have vinished."

Another reason why Kingfishers are sometimes killed is that they eat small fish, including the foung of trout and other fish, which are preserved and bred for sport. But. there are more destructive enemies to these than Kingfishers, and if the other enemies are kept down I do not believe that the stock of fish in any river will be seriously affected lyy Kingfishers, and the sight of them certainly adds a great deal of heauty and interest to it day's fishing.

'The Kingfisher nests in bauks, in a hole either of its own or of some other creature's making, and as the hole is of some depth it is generally impossible to see the exgre without digging them out and destroying the nest, which shonld never be done. The shell of the egg is white, but it is so transparent that the colour of the jolk shows through and gives it a delicate orange tinge. I only once saw a fresh egg, and that was under very exceptional circumstances. An old willow by the side of a stream had been blown down and lay prone, having lifted up a large piece of the bank with its roots: the willow still lives, and grass and weeds still grow on what was the surface and is now the front side 
of its roots; but at the back, orer the stream, the earth is bare, and here there are many Loles. At one of these, early in April, 1894, Kingfishers were feeding well-grown young birds ; later on, in the middle of May, Kingfishers were still haunting the willow, and amongst the grass on the front side a little opening was found, where the soil had fallen out of a chink between two strong roots. Behind these was the nest, in which about seven eggs could be seen, and one was taken out with a twig, for the nest could not be reached through the chink with a finger, and the proper entrance was a hole some feet away on the other side. It was some time before I saw the nest again that season, but the place was not disturbed, and from what I did see afterwards this second brood also was apparently reared successfully. When the young birds are old enough they seem to creep to the mouth of the hole and take the little fish from the old bird, who clings on outside. The eggs in the instance given were surrounded as usual with the dibris of small fish, which had accumulated during this or previous nestings.

The Kingfisher generally watches for its food sitting motionless upon a branch overhanging the water, but some authors say that it also at times hovers on the wing, like a kestrel, looking for its prey. The Kingfisher darts down upon its prey with great speed, and, when it comes out of the water with a little fish, flies off with it to a branch or stump, and, before swallowing, kills it with a few blows against the wood. The dart of the Kingfisher into the water is not a flight down, but a dive: a header taken with great force and closed wings.

The note of the Kingfisher is compared by many writers to the piping of the common sandpiper. When disturbed it is very shrill indeed, and plaintive, as if the bird were complaining. Indeed, the constant persecution for the sake of its beauty gives sad enough reason for complaint, and we owe the preservation of the species partly, perhaps, to the swiftness of its flight, but mostly to its extreme wariness and unobtrusive habits. It is a very shy bird, and prefers solitude, as if, being so brilliant, its only chance of escaping notice was to be quiet and alone. So shy is it that often enough it flies long before it is seen, and the only sign one has of its presence is the shrill plaintive piping as it flies rapidly away. The late Tord Tilford says, however, that where it is not persecuted it rewards mankind by becoming "ver fearless and even familiar," and that once a Kingfisher settled on a fisbing rod which was resting over the side of a punt in which he was at luncheon.

Educational Series.-No. 1.-OWLS. No. 2.-WOODPECKERS. No. 3.-STARLING. No. 4.SWALLOWS. No. 5.-KINGFISHER. No. 6.-OSPREY. No. 7.-DIPPERS. No. 8.-NIGHTJAR. No. 9.-TITMICE. No. 10.-KESTREL. No. 11.-PLOVERS.

Others in course of preparation.

Copies of the above may be obtained from the Society's Publishing Department, Knowledge Office, 326, High Holborn, W.C., or from the Hon. Sec., Mrs. F. E. Lemon, Hillerest, Redhill, on the following terms:-Post free: three copies of any one number of the Series, 1d, ; one dozen, 3d.; 100, 1s.6d. Assorted packets, one copy of any sis numbers, $2 d$.; one copy of any twelve, or two copies of any six numbers, $4 \mathrm{~d}$; or 50 assorted numbers, $1 \mathrm{~s}$. Special terms for larger quantities, and to County Councils, the Constabulary, and Schoo's. 


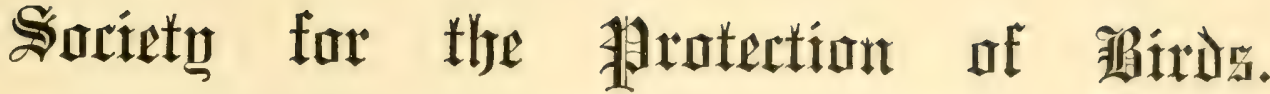

EDUCATIONAL SERIES. Edited by H. E. DRESSER, F.L.S., F.Z.S.

No. 6.-OSPREY.

By J. A. HARVIE-BROWN, F.R.S.E., F.Z.S.

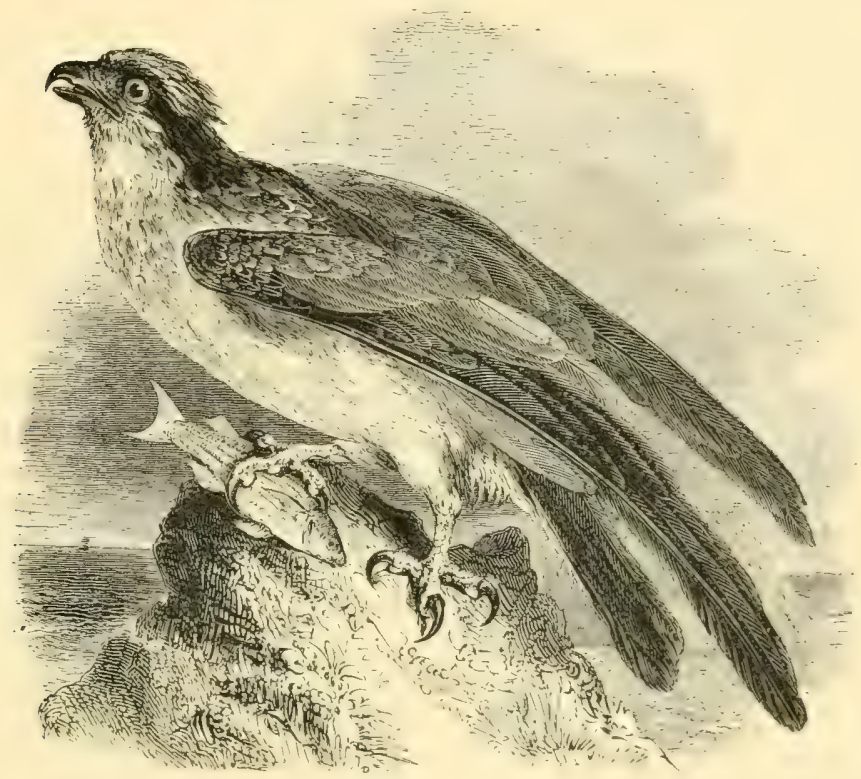

OSPREY.

\section{Name.-OSPREY.*}

Family-Falconidx.
Genus-Pandion.
P. haliætus.
The Osprey.

\section{General Description and Proportions.}

Adult, male: Head white, striped with dark brown; ear-coverts and a stripe to the hind neck blackish-brown; upper parts dark brown with a purplish gloss; under parts white, the breast marked with brown; legs and cere lead blue, iris, yellow. Total length about 23 in.,

* Notz. - Not to be confounded with the Osprey plumes of commerce, so often alluded to by this Society

Illustration, by kind permission of Messrs. Gurney \& Jackson, from "Miauual of British Birds," by Mr. Howard Saunders. 
wing $19 \frac{1}{4} \mathrm{in.}$, tail $8 \frac{3}{4} \mathrm{in}$. The female is larger lut otherwise resembles the male, and the young bird has the feathers on the upper parts edged or tipped with white; the breast feathers are pale brown, edged with white, and the tail is distinctly barred.

\section{Where, when, and in what Number's found.}

The Osprey inbabits a vast area of both the Old and New Worlds, from the further forest growths in the north of both Continents to Australia and New Zealand, and some of the Pacific Islands in the Old, and down to Brazil in the New. Abundant where least disturbed among the great forests of the north; scarce in Britain. Nests only in a few personally preserved localities in Scotland.

\section{Food.}

Almost entirely fish-salmon, grilse, trout, pike; and the last-mentioned is favourito food, and often the most easily obtained, though grils? or salmon are preferred, though not always so easily canght, as the Osprey rarely strikes a fish unless it is pretty close to the surface : fresh-water fish principully, hut also certain species of sea-fish such as shad. It is specially fond of carp. which at certain seasons are also easily obtained on the shallows, or in marshy rumnels.

\section{Characteristics.}

Except where constantly subjected to annoyance or disturbance at their breeding-haunts, the Osprey is not a shy bird as compared with some other persecuted Raptores. Hence, it is easily approached and destroyed during the migration season, when old and young leave their summer homes. Ospreys have regular times at which they fish, usually at some distance from the nest and young, and often flying orer the same routes to and from their feeding grounds. They build a hulky nest on tall trees or ruinous buildings, usually in forest land studded with lakes or intersected by rivers. In America they nest often in large colonies, but, so far as ascertained, only in single pairs in Europe. But there may be said to be almost the commencement of a colony at one locality in Scotland, owing to the strict personal protection thero afforded to the species for many fears past. The Osprey renews its nest yearly, lmilding upon the previous structure, lut is apt to hecome disgusted if the said original structure is interfered with or the materials persistently carried off by other birds.

\section{Protection.}

Its protection by law is not fully provided for, whether at its nesting-haunts or during the migrations of old and young.

Wild Birds Protection Act, 1880* - These birds do not appear in the schedule, but are protected during close time except as against owners and occupiers of land. The Osprey has, however, been added to the Schedule in the following counties:-

* Generally from 1st March to 31 st July, but in some counties from 1st February to 31 st August in each year. A further period may be obtained through the Act of 1896. 
England:-Durham; Northampton; Deron; Kent; Metropolitan Police District including London and Middlesex; Somerset; Wilts.

WaLES :- Pembroke.

Scotland :-Dumfries; Elgin; Kirkcudbright; Wigtown.

Wild Birds Protection Act, 1894. - The eggs are protected (1896) in the following counties :-

England :-Gloucester; Leicester ; Stafford; Warwick; Devon; Keut; Metropolitau Police District, including London and Middlesex.

Scotland :-Dumbarton; Dumfries; Elgin ; Kirkcudbright; Wigtown.

Wild Birds Protection Act, 1896. - In addition to any penalty under the Act of 1880 , the Court may now order any trap, net, snare, etc., used by the offender, to be forfeited.

The Osprey is protected throughout the whole year in the county of Middlesex.

NoтE.-The eggs are not protected specially by any County Council's adoption of the Act, because none of the counties where the species is found nesting have adopted the Act. To protect the species thoroughly the Act would have to be adoutecl in all the counties, not only where it breeds nor, but also in all the counties where it formerly bred. And its further protection should be provided for in many English and Scottish countips through which it passes on migration. Dumbartonshire has wisely profited in this respect, and that example should be followed by others.

It receives, however, private and personal protection at its nesting-haunts, which, lowever, is in great degree rendered vain by the selfishness of collectors and shore-poppers, and even, in some instances, the undiscriminating game preservers- $-\pi$ cannot call them "sportsmen" in the best and truest sense of the word.

\section{Remarks.}

The history of Scottish Ospreys goes bark into the last century, whence the chronology of their dates, with here and there a hiatus, extends down to the present time. That is to say, we have sufficiently continumes datal to mark distinetly their almest. if not quite, continuous oceupation of many sites in Scotlamd. But at the present day these numerous sites, principally by the cupidity of private collectors, bave heen long deserted, ant the places that once lnew these fine and harmless birds linow them no longer, and the glory has departer? from many an ancient stronghold. It is not necessary here to so into chronological detail of the occupancy of all of these sites, but we desire to spreals of one an two only, and of these very shortly.

The earlier writers-Pennant and others-and the old Statistical Accomnt mention the Ospreys of West and East Inverness-shire; and arly in the nineteenth century columel Thornton also speaks of their rarity even then-so far as he knew-aml of the presenen of Ospreys in Glemmore. The geologist MacCulloch also spoke of them in Rothiemurhus in 1824; and links of evidence of their continunce there are easily picket up hy those who have made special study and enquiry, rumning almost minterruntedly from 18.13 (Carruthers) to 1852. A break in chronology then occurs, - but not necessarily in occupancy, - but we find again records in 1879 and 1880 , perhaps continuonsly down to 1888 , when, we ascertain, thit 


\section{$\left[\begin{array}{ll}4 & 1\end{array}\right]$}

once more disturbance and greed intervened. Nevertheless, occupancy continued down to 1887 , when a grievous thing happened in an adjoining county, at a new site never before occupied, followed by a vicious battle between surviving birds in 1888 . We cannot in this place relate all these grievous circumstances, but we give our own experiences in 1892, which will, we believe, suffice to call forth expression and condemnation of the acts, and assist, we sincerely trust, in influencing those who can do so to protect our Ospreys of the future.

We visited an Osprey's nest in Strathspey one day in early May, 1892. One bird alone was seen. The nest was complete, even to the last shred of lining, but empty. We picked up a first primary wing-feather at the root of the tree, beneath the nest, shot-shattered. The direction of the shot was clearly traceable, gapping the inner web at one place, and searing the rest of the web in the direction of the body. 'The shot must have then struck the wing hone close to the base of the quill (right ring), causing distention, or otherwise cutting or affecting the muscle, resulting in the casting of the quill. The quill appeared perfectly fresh ; so fresh, indeed, that we came to the conclusion at the time-one which became strengthened afterwards - that the eggs were taken and the old bird shot early on that same Monday morning, or on the previous day.

We hope some steps can be taken by the proprietors of land where the Osprey still holds precarious domicile; and, indeed, one step towards the desirable attainment-the perfect preservation of these now rare and harmless birds-has been taken by a well-known and influential society - the Zoological Society of London. This Society has repeated the wise policy inaugurated in 1890, when they awarded their chief medals for the preservation of another of our own rare species-the Great Sliua-in Shetland. We believe proprietors of Osprey-haunted homes will double or treble their energy, and resolve that such shameful treatment be guarded against for ever in the future. We write purely in the interest of our feathered friends, and, as the season advances now, it is not too early to publicly draw attention to the state of affairs in Ospreydom, in further preparation for 1897.

The two medals of the Zoological Society have heen awarded to the present representatives of the families of Grant of Rothiemurchus-the present proprietor being John Peter Grant, Esq. ; and Cameron of Locheil-the present proprietor being Donald Cameron, Esq.

The above notes were written in 1895. Since then the Ospreys of Rothiemurchus have twice taken off their young, and an additional site has been occupied on Locheil's property. Alas! however, birds continue to migrate and suffer death at English and other localities, far removed from their breeding haunts, and it is here, perhaps, where we, who desire their protection, most require the aid and application of the law.

\footnotetext{
Educational Series.-No. 1.-OWLS. No. 2.-WOODPECKERS. No. 3.-STARLING. No. 4.-SWALLOWS. No. 5.-KINGFISHER. No. 6.-OSPREY. No. 7.-DIPPERS. No. 8.-NIGHTJAR. No. 9.-TITMICE. No. 10.-KESTREL. No. 11.-PLOVERS.

Others in course of preparation.

Copies of the above may be obtained from the Society's Publishing Department, Knowledge Oflice, 326, High Holborn, W.C., or from the Hon. See., Mrs. F. E. Lexon, Hillerest, Redhill, on the following terms:-Post free: three copies of any one number of the Series, 1d.; one dozen, 3d, ; 100, 1s.6d. Assorted packets, one copy of any six numbers, 2d.; one copy of any twelve, or two copies of any six numbers, $4 \mathrm{~d}$; ; or 50 assorted numbers, 1s. Special terms for larger quantities to County Councils, the Constabulary and Schools.
}

The Society's Publishing Office, Knowledge, 326, High Holborn, London, W.C. 1896. 


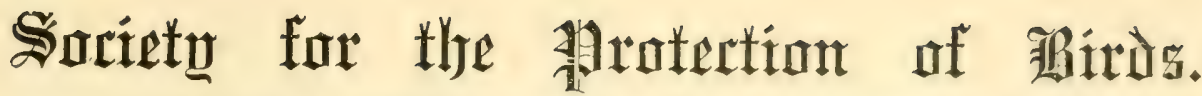

EDUCATIONAL SERIES. Edited by H. E. DRESSER, F.L.S., F.Z.S.

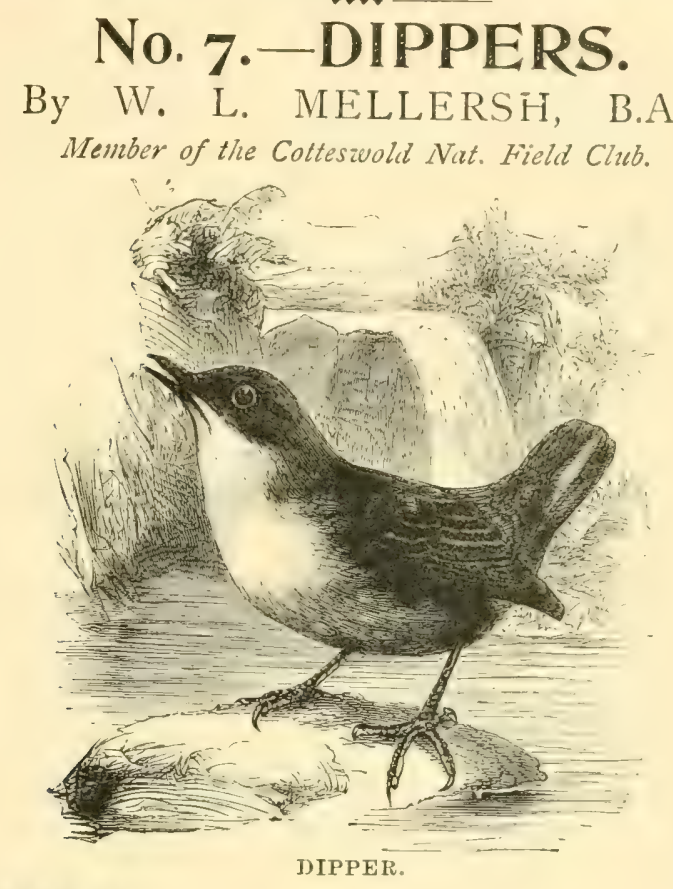

\section{Name.-DIPPER,}

Family--Cinclida.

Genus-Cinclus.

1. Cinclus aquaticus.

2. Cinclus melanogasta.

The Dipper.

The Black-bellied Dipper.

Other names: "Water-Ouzel" (because once thought to belong to the Ouz,l, i.e., the Thrush Family), "Water Colly" (in and from Somerset, westward), "Water Crow," and "Water Pyet" (in Scotland).

\section{General Description.}

Dipper.-Colour above, dark grey and black, head and nape anber low wr, throat and upper breast white, lower breast dull red, passing into black and slatish brown on the rest of the under parts. Length, $6 \frac{3}{4}$ inches; wing, $3 \frac{3}{4}$ inches. A darlier form seems to appear on higher ground; e.g., in Derbyshire, birds found at a height of 1500 feet are darker than those at 500 feet only. This form, still much darker, is the subspecies next described.

Black-bellied Dipper.-Same as the above, except that the dull red is repliteer by ditriti brown or black, and the bird is a trifle larger.

\section{Where, when, and in what numbers found.}

1. The Dipper. - A resident in the counties south of the Bristol C'hammel, in IViales and Derbyshire, and thence northward to Scotland and in Irelami. Fery rime in the Fisst of England; found chiefly as an oceasional visitor to other counties, though brecling in a few suitable localities. 
2. The Black-Belited Dipper.-This form takes the place of the other in the East of England, but only as a winter visitor from Scandinavia and North Russia. There it has its home and leads a hardy life.

\section{Food.}

An insect diet, such as spiders, water beetles, and caddis worms. The birds, too, eat small molluses and "bullheads."

\section{Characteristios.}

The Dippers only live by such a river or brook that sings-

"I chatter" over stony ways, in little sharps and trebles;

I bubble into eddying bays, I babble on the pebbles;"

and in their shyness they are as restless. Their nest is domed, about a foot high, not so broad, and made of moss-such as the greater water moss, which grows on the beds of streams. Sometimes this is mixed with hay, but it is always very closely matted together, about three inches thick at the top and less at the sides, with a little mattress of hay and leaves for the eggs. It is tucked into a shallow hole in the rocks, or under the roots of a tree, or behind a waterfall, and the entrance is low down on the side. The eggs are white but not glossy.

\section{Protection.}

Wild Birds Protection Act, 1880.-This bird does not appear in the Schedule, but has been added to it in the following counties:-

ENGLAND-Lancaster.

WALES-Pembroke.

Scotland-Berwick; Dumfries; Elgin; Kirkcudbright; Wigtown.

Any owner, occupier, or other person taking, killing, etc, a Dipper during cluse season, * in the above-named counties, is liable to a penalty of $£ 1$ for each bird. In all other places the Dipper is protected during close time except as against owners and occupiers of land, the maximum fine for each bird being $5 \mathrm{~s}$.

Wild Birds Protection Act, 1894.-The eggs are protected in the following counties:-

Engrand-I. Northern.-Cumberland; Durham; Westmoreland; and the breeding

areas in Northumberland; York, East Riding. II. Midland.-Breeding areas in Cambridge; Chester; Norfolk; Lincoln; East Suffolk. III. Southern.-Devon and the breeding areas in Essex; Kent; Isle of Wight.

Scotland-Berwick; Dumfries; Elgin; Kirkcudbright; Wigtown.

IRELAND-Roscommon.

Any owner, occupier, or other person taking or destroying a Dipper's egg in any of these places is liable to a penalty of $\mathfrak{E 1}$ for each egg.

Wild Birds Protection Act, 1896.-In addition to any penalty under the Act of 1880 , the Court may now order any trap, net, snare, etc., used by the offender to be forfeited.

\section{Remarks.}

The world would think that a little bird such as this, with its quiet look of innocence, lonely unambitious habits, and sombre plumage, would certainly have escaped persecution. However, fortune has not created the bird an exception, for its share of persecution has been meted ont, and that by anglers. Everywhere, from the Highlands-where the Dipper is also known as the "Kingfisher" - southward, it has been accused, and in uncounted numbers it has been destroyed. The belief has been that it fed on the eggs and tiny young of salmon and trout. But 250 years ago, Isaac Walton was right when he omitted its name from his accurate list of the enemies to those fish. Other anglers who lived about his time might have thought differently of its claim to innocence; yet, if so, as much poets as anglers in bygone days of peace, they doubtless said with him that they "loved to kill nothing but fish." "The crusade

* Generally from 1st March to 31st July-but in some counties from 1st February to 31st August in each year. A further period may be obtained through the Act of 1896 . 
against the bird was probably only begun when anglers became numerous, and anxious that ne'er a fish should be lost on their limited waters. But this was before the ditys when erery theory calls for proof. Now it is known that the Dipper scarcely harms a fish of sport, but, on the contrary, does a vast amount of good. It rids all streams wherein it feeds of those insects which, at certain stages of their existence, are, as well as "bullheads," most destructive to the eggs of salmon and trout. As its usefulness becomes widely known the bird may again become common-another English pet, a Robin of the brook, yet safer than a Robin, for its nestlings can, at any rate, never be troubled by the modern eat! Along one trout stream that I know, the bird has ceased to be molested since its virtues liave become known, and where it was formerly but a visitor several pairs now live and breed. There would be more there were it not for the fact that each pair is jealous of its own hom daries. A part of every stream where the birds are found belongs to one pair of them, and they, as well as we, have a law of trespass.

To know the birds as they are, one must gro down this allotted part of some hill stream. The water rushes, bubbles, and eddies, over and amil stones and moss; where white froth and black pools contrast with the colours of the lird they hide. Slowly and stealthily must movements be made, not one stey further forward until the eje is sure that at the back of the stone, or round the corner of the brook coming into view, there is no Dipper.

That it is being sought in winter matters not. Though icicles and hroken tiles of ice make chill the banks with little wintry vaults beneath, food is still to be found in troubled water, and that is all the bird wants. Such a haunt--shaded, too, by a few fir trees and flecked by birches-cannot fail to hold what one is seeking, and, if careful, the search is soon rewarled. The bird stands there in its favourite spot, on some small loose stones at the edge of the dark pool, with its feet lapped by the ever moving water, and its back anon splasheil by the little? waterfall hard by. It moves little then, for its short lecrs and curved claws are ill aldated for walking, and it has no claim to elegance like its fellow-tenment of the stream, the Grey Wagtail. The Dipper's short tail poised upwards rivals that of the Wrem ; its stolic form partly bowed makes jerky bobs more of ten than does a Robiu's, and when seen in its straight flight it more resembles a ball thrown from the hand, so little are its wings extended. Its first morsel of food may be close by, so, merty bobling more than usual, the Dipper's heant and neck are in and out of the stream with a little flop and a splash. But it is a waterloving bird, and ere long its next move evades the sight as it flies to the centre of the eddying pool, seems to rest for a moment, with its white breast embraced by the snowy froth, and then is gone-diving to the bed of the torrent.

Other birds, such as the Kingfisher and Tern, plunge in from a height; but the Dipper flies on to the water, floats there for a moment, and then plunges or sinks in. With its body covered with small white bubbles, and slanting down leeid formost, it propels itselft. with sharp jerks even against the current, making its powerful wings do duty for its unwebbed feet. It flies in the water. Its wings have been seen well stretched ont, gallintly fighting the rapids, until it reaches the bottom. There its curved (claws help it, as it lerolis into crevices and under stones for its food. Presently it comes up at the top of the "urrent, seemingly flings itself on to a store, remains still for a moment, make's a hol, catches sight of its visitor, and uttering a weird little shriek darts down the stream. If it is followed, too quick are its ejes now not to catch sight of one the moment it is seen, and again it will hitre to be followed; probahly in constant similar starges to the end of its lomains. Then with a swift rise into the air, uttering again and again its shrill notes, it flies bark high overheaul whence it came. Those notes, those weird shrieks, more than doulded by the lonely valley, are caught up by the enchaining hills, and seem to thrill one with a sense' of lurking danger. until they cease amid the tiers of firs in the mist. If still pursued it might grant one at chance in the wintry twilight of hearing its song-the warbling strain of a birct haply all the year round, never tired with its wild life and unchanging source of food.

Scarcely again, though, will there be such a beautiful sight as that once seen hy IIr. Robert Gray in Lanarkshire. A wild stream wiss swollen, and in the eentre, where the current was slow, floated a detached piece of turf frozen in ice. On this stood a dipper, singing, as dusk fell on all around, its evening hymm, thrilling the rugged and sterile surroundings with the 


\section{$\left[\begin{array}{ll}4 & ]\end{array}\right.$}

outburst from a little heart, thankful that in the midst of that cold scene it was ever able to live and be warm. It sang on quite regardless of its danger, until some rapids were approached, when, seeing its change of position, it sprang from its perch, and flew up the stream, to rest for the coming day.

In early March-unless a late season-when the days begin to get bright, and the evenings are clear and still, except for the melody of the first spring songsters, it will commence its nest. Then it seems regardless of man as it chases its mate with the same sharp cries up and down and round the stream. Then, too, when the early rays of the morning sun are dancing on the ripples, it sings close to man's abode. At some old-fashioned mills I know, the inmates delight in this, as it sits outside, on some old wooden post green with moss, and warbles a subdued love ditty. But the old birds are most cautious in building their nest, swiftly flying to the chosen site, and, if observed, in the same moment doubling round and away with the unused material. What a home, too, it is when finished; defying the water that splashes on it, and the eyes that would find it amid its like surroundings! What firmness, too, either parent will show in keeping to its eggs when once it has been discovered on the nest, and even after it has been actually handled on it.

When the young first come out with the may-blossom, and float and play and dive in the water, one can also see them taught to fly. This an old bird will do, sitting for once in a way on a low stout branch, and flying from it a little distance with the small pupils behind. About this time, too, another unusual sight may be seen. The young birds will settle on the top branches of such a tree as a swaying birch, to glory in the strength of their curved claws. They soon equal the parent birds in all they do, and then leave the old home, and work their own way in the world, whilst in the same nest the old birds will rear another, or, rarely, even two more broods.

As has been shown, the bird has every claim for protection. T'he boon it confers on anglers is undoubted. One of the greatest points in favour of this is from the works of the late Mr. Francis Day, author of "The Fishes of Great Britain and Ireland." He showed that the above-named food of the Dipper is also the worst enemy to salmon and trout, but he found only one instance of the bird, out of the hundreds he examined, having eaten the eggs of a trout, and in this instance the bird may have been driven by hunger to feed on the fish spawn.

In other ways, too, no bird rewards its protectors more. Its real attraction is the bed of a stream; whether it be like that described, or one on barren moors, or in the low-lying vale of a southem county. In the latter I have found the birds living close to a farm meadow with nought for them except water madly rushing over a broken stone dam, the greater water-moss, and their food. But the farmer, and especially bis boy, have watched and cared for it and have protected its nest. They have seen its amual two broods brought up, they have delighted in most of the sights described and in the song, and the old birds stay on to reward them. This shows how the Dipper mar spread if properly protected. The race is truly English in courage and thoroughness, as also in its love of the water and affection for its young brood. Our attachment through years and generations to the sime home is theirs also, and the birds, if protected, will enable many persons in the future to say what one person I know has said: that he can vouch for a pair of Dippers having nested in the very same spot every year for half a century, and he does so with gratitude.

Educational Series.-No. 1.-OWLS. No. 2.-WOODPECKERS. No. 3.-STARLING. No. 4.SWALLOWS. No. 5.-KINGFISHER. No. 6.-OSPREY. No. 7.-DIPPERS. No. 8.-NIGHTJAR. No. 9.-TITMICE. No. 10.-KESTREL. No. 11.-PLOVERS.

Others in course of preparation.

Copies of the above may be obtained from the Society's Publishing Department, Knowledge Otfice, 326, High Holborn, W.C., or from the Hon. Sec, Mrs. F. E. LEstos, Hillcrest, Redhill, on the following terms:- Post free: three copies of any one number of the Series, 1d.; one dozen, 3d.; 100, 1s. 6d. Assorted packets, one copy of any six numbers, 2d.; one copy of any twelve, or two copies of any six numbers, 4d; or 50 assorted numbers, 1s. Special terms for larger quantities, and to County Councils, the ConstabuTary, and Schools.

The Society's Publishing Office, Knouledge, 326, High Holborn, London, W.C. 1896. 


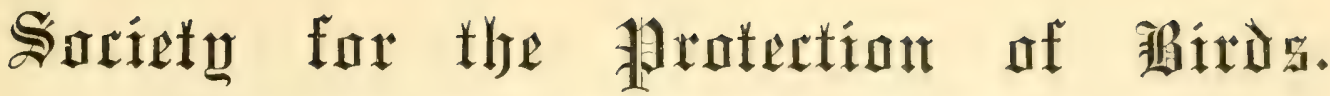

EDUCATIONAL SERIES. Edited by H. E. DRESSER, F.L.S., F.Z.S.

\section{No. 8.-NIGHTJAR.}

By MONTAGU SHARPE, Depy.-Chairnan aliddlesex Q. Sess, and Cy. Conncil.

"While o'er the cliff th'awaken'd churn owl hung

Through the still gloom protracts his chattering song." Gilbert White.

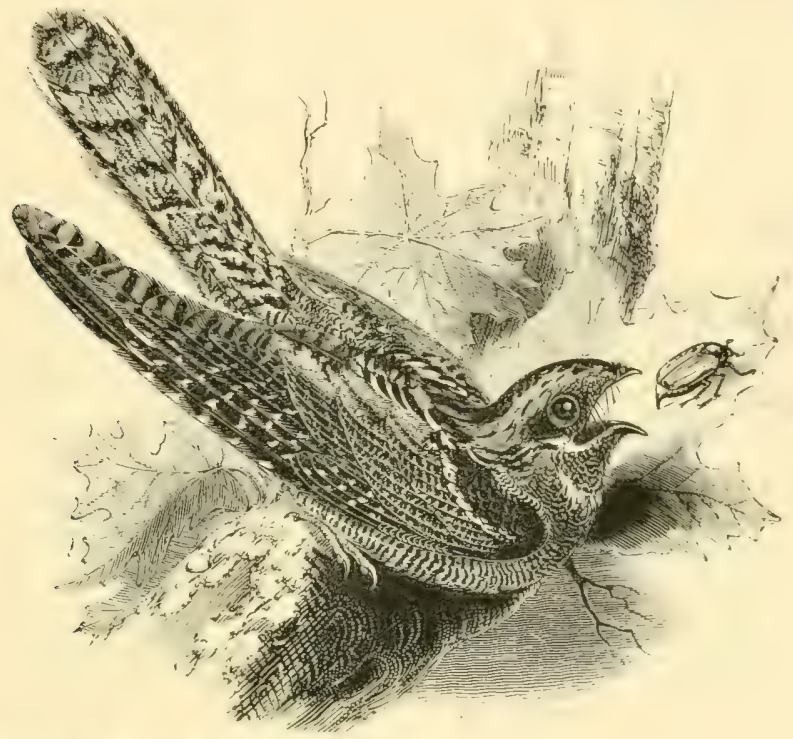

\section{Name-NIGHTJAR.}

Family-Caprimulgidæ.

Genus-Caprimulgus. C. europeus. Nightjar, Nighthawk, Fern Owl or Goatsucker.

\section{General Description and Proportions in inches.}

The feather's are of a greyish white, occasionally varied to buff, but generally nearly concealed with delicate pencillings of dark grey or buffy grey, and shaft lines and obscure bars of nearly black. The under side of the wing is of a lighter shade. The male bird is distinguished by white tips to the outside tail feathers, and by patche's of white on the cheeks. throat, and wings. Tip of beal to tip of tail, 10 ; wing, closed, $7 \frac{1}{2}$; tail, $5 \frac{1}{4}$; body, $4 \frac{1}{2}$.

\section{Where, when, and in what Numbers found.}

England, Scotland, and Ireland. The Nightjar is more numerous in the Suth than in the North of England. It is not a gregarious bird, and is generally to be foumel amongst bracken, furze, and brambles on heaths, moors, or open spaces bordering on woods.

It is one of the latest migrants to arrive on our shores, generally appearing in about the

Illustrations on pages 1 and 4, by kind permission of Messi's. Gurney \& Jackson, from "Manulal of British Birds," by Mr. Howard Saunders. 
middle of May and leaving in Septembsr, but it has been linown to stay in the south-west of England as late as November.

This harmless, interesting bird is, alas! too often shot down in the mistalien belief that it is a hawk.

\section{Food.}

Cockchafers, moths, and nightflying insects.

\section{Characteristics.}

Like the owl, the Nightjar possesses the peculiar habit of ejecting from the mouth pellets consisting of the indigestible remains of the food it has swallowed, and it is likewise a nocturnal bird, hunting for its food when the sun is below the horizon.

During the day it sits quietly in a sheltered spot on the ground, or perches lengthwass along a bough, and not across it.

There are large bristles on the gapes, and at the side of the middle toe there is a horny development divided into slits, which are supposed to be for the purpose either of clearing off parasitical insects with which this bird is infested, or for the better clinging on to the sides of a branch when seated longways upon it, or for cleaning the bristles on the gape from the débris of winged insects, but it is not yet definitely known for what this serrated claw is used.

\section{Protection.}

Wild Birds Act, 1880.- This bird appears in the schedule, which applies to every county in England, Scotland, and Ireland. Any owner, occupier, or other person taking, killing, etc., a Nightjar during close season,* or possessing or selling a Nightjar after 15th March, penalty $\& 1$ for each bird.

Wild Birds Act, 1894.-Its eggs are protected at present (1896) in the following counties or specified breeding areas in counties : †-

Engldnd.-I. Durham; Northumberland, specified breeding area, Holy Island; Yorks., E. Riding, specified breeding area, Promontory of Spurn, including Kilnsea Warren. II. Bedford; Cumbridge, specified breeding area, Wicken Sedge Fen ; Chester, specified breeding area, Hundred of Wirrail; Gloucester; Leicester; Lincoln, (Kesteven and Lindsey); Norfolk, specified breeding area (1), Hickling, Ormesby, Rollesby, Hemsby, Filby and Burgh Broads; (2) North Wotton and Cley-next-theSea; Northimpton; Stafford; East Suffolk, specified breeding area, sea coast from River Blyth to Languard Point; West Suffolk; Warwick; Worcester. III. Devon; Essex, specified breeding area, Shoeburyness, and three tidal rivers; Hertford; Isle of Wight; Kent, five specified breeding areas; Metropolitan Police District, including London and Middlesex.

WALES-Brecon; Pembrolie.

Scotrdnd-Aberdeen; Dumbarton; Dumfries; Elgin; Kirculbright; Wigtown.

IRELAND-Roscommon.

Any owner, occupier, or other person taking or destroying a Nightjar's eggs, penalty $£ 1$ for each egg. Its eggs are white, marbled and clouded with grey and brown, and measure about $1 \frac{3}{10} \times \frac{9}{10}$ inches.

* Generally from 1st March to 31st July; but in some counties from 1st February to 31st August in each year. A further period may again be obtained through the Act of 1896 as in Middlesex. 1894 .

+ It is expected that other counties will before long obtain similar orders of protection under the Act of 
Wild Birds Act, 1896. - In addition to any penalty under the Act of 1580 the Court may now order any trap, net, snare, etc., used by the offender to be forfeited. This bird is protected throughout the whole year in the County of Middlesex.

\section{Remarks.}

The Nightjar, being a voracious feeder on winged insects, has haell wisely protecterl by the Legislature, and on account of the benefit it confers on mankind it should be welcomed and left unmolested.

Many silly prejudices have sprung up concerning this bird, since its hathits are not mush observed, owing to the fact of its flying about during the hours of night. It is the victim of numerous local names or aliases, all more or less suggestive of its habits and peculiarities. "Fern Owl," because it is frequently to be met with amid ferms and braclien, on moors and heaths, and on account of its noiseless dextrous flight during the hours of night.

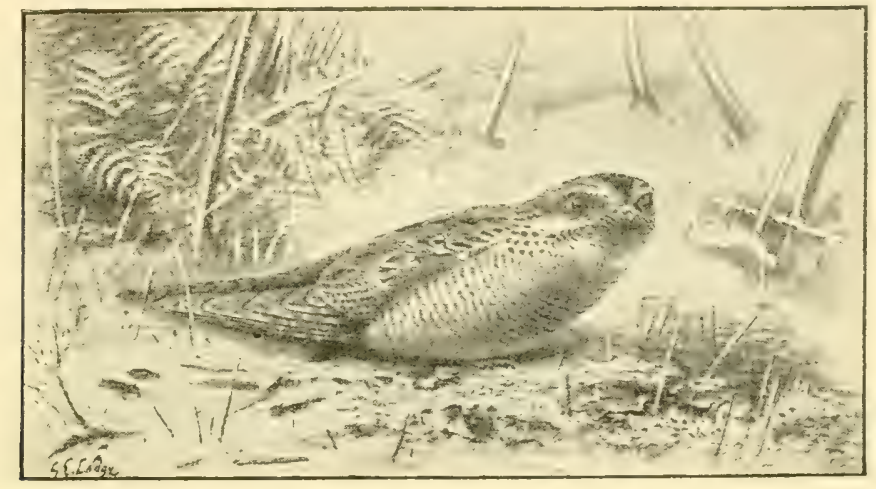

"Goatsucker," from an ancient and silly superstition that the bird can driw milk from a goat, "probably arising," as Seebohm remarks, "from the wideness of its gatpe and from the fact that the poor harmless bird hawks over the sleeping herds to catch the insects founa in their vicinity." "Nighthawk" or "Dorhawk," on account of the bawklike manner in which it beats about for insects, while its beak and claws are too weak to catch birds or mice. It is also named "Wheelbird," "Churn Owl," "Eve-Jar," or "Jar" Owl," ete.

As the owl continues at nightfiall the grood work of the kestrel, so does the Nightjar that of the swallow and swift. But while the Nightjar can twist and turn with nearly the fiteilit! of the swallow when searching for insects over the tops of trees, it is neither swallow, hawli, nor owl, but is a most interesting and useful bird, one of a fimily of some serenty species which are found throughout the world.

Only two species, the Red-necked Nightjar and the present speecies, however, hreed in Europe, one of which is this summer migrant to our shores, while the other is linuwn to hitwe come orer only once, and therefore need not be referred to in this leaflet. A third specie's, the Egyptian Nightjar, has also once occurred in Great Britain.

The Nightjar does not make a nest, but deposits its eggs, two in number, on the ground,

Illustration, by kind permission of Messrs. Longmans, Green \& Co., from "British Birds," by MIr. W. H. Hudson, C.M.Z S. 
ur on short moss, frequently in open patches on heaths. The eggs, which measure about $1.20 \times 0.85$ inches, are white, blotched and marbled with blackish brown and purplish grey.

The note of the Nightjar, when perched, is like the loud and prolonged purr of a cat, or a "ch-u-rr"-like soumh, which on still evenings may be heard at some distance; but while on the wing its common note is a clear and somewhat rapidly repeated "coic, coic."

"Gamekeepers either shoot the Nightjar in the belief that it is a species of hawk, or they nail it up in their museums along with cuckoos and liestrels to increase their show of vermin, under the impression that their employers will not discover that these birds are not hawks of some kind that are injurious to game."

I will conclude with a couple of extracts from letters written in 1769 by that delightful naturalist, Gilbert White, of Selborne:-“ . . There is no bird, I believe, whose mamners, I have studied more than those of the Caprimulyus, as it is a wonderful and curious creature;
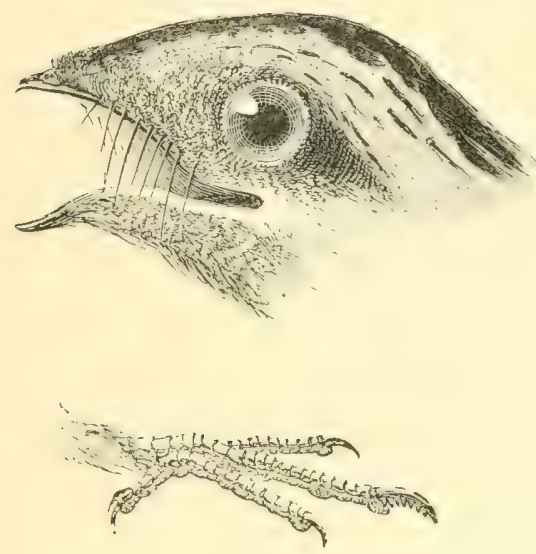
but I have always found that, though sometimes it may chatter as it flies, as I know it does, yet in general it utters its jarring note sitting on a bough, and I have for many a half hour watehed it as it sat with its under mandible quivering, and particularly this summer. It perches usually on a bare twig with its head lower than its tail. This bird is most punctual in beginning its song exactly at the close of day; so exactly that I have known it strike up moxe than once or twice just at the report of the Portsmouth evening gun, which we can hear when the weather is still. It appears to me past all doubt that its notes are formed by organic impulse, by the powers of the parts of its windpipe formed for sound, just as cats purr . . ." “ . . The powers of its wing were wonderful, exceeding, if possible, the various evolutions and quick turns of the swallow genus. But the circumstance that pleased me most was, that I saw it distinctly, more than once, put out its short leg while on the wing, and, by a bend of the head, deliver somewhat into its mouth. If it takes any part of its prey with its foot, as I have now the greatest reason to suppose it does these chafers, I no longer wonder at the use of its middle toe, which is curiously furnished with a serrated claw."

(Some of the above information taken from "British Birds," Seebohm, and "Our Country's Birds," TV. J. Gordon).

Educational Series.-No. 1.-0WLS. No. 2,-WOODPECKERS. No. 3.-STARLING. No. 4.-SWALLOWS. No. 5.-KINGFISHER. No. 6.-OSPREY. No. 7.-DIPPERS. No. 8.-NIGHTJAR. No. 9.-TITMICE. No. 10.-KESTREL. No. 11.-PLOVERS.

Others in course of preparation.

Copies of the above may be obtained from the Society's Publishing Department, Knowledge Office, 326, High Holborn, W.C., or from the Hon. Sec., Mrs. F. E. Lesron, Hillcrest, Redhill, on the following terms:-Post free: three copies of any one number of the Series, $1 \mathrm{~d}_{0}:$ one dozen, 3d, ; 100, 1s. 6d. Assorted packets, one copy of any six numbers, 2d. ; one copy of any twelve, or two copies of any six numbers, $4 d$; ; or 50 assorted numbers, 1s, Special terms for larger quantities to County Councils, the Constabulary and Schools.

The Society's Publisking Office, Knouledge, 326, High Holborn, Iondcn, W.C. 1896. 


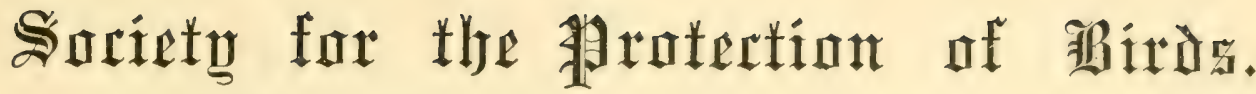

EDUCATIONAL SERIES. Edited by H. E. DRESSER, F.L.S., F.Z.S.
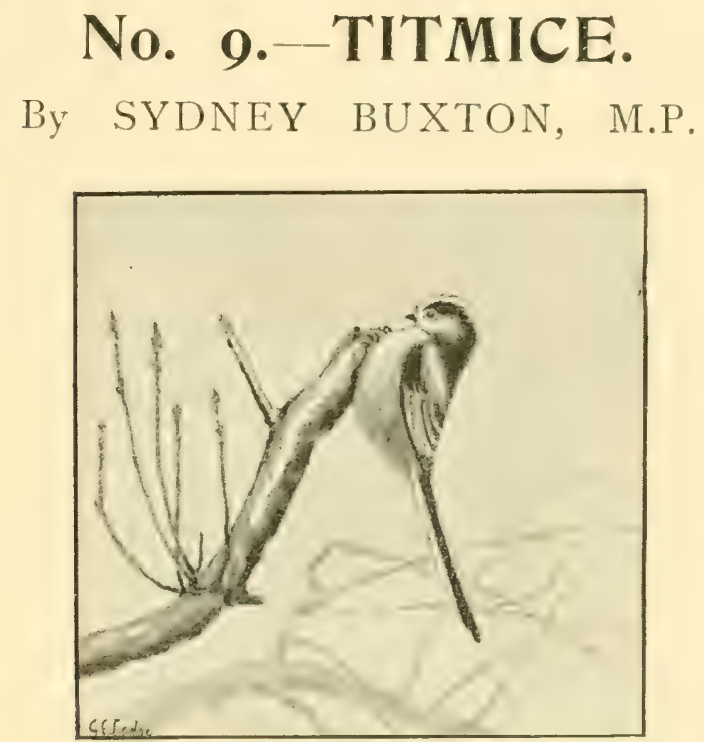

LONG-TAILED TIT.

\section{Name.-TITMOUSE.}

Family-Paride.

Genus 1.-Acredula.

Genus 2.-Parus.

Genus 3.-Lophophanes.
A. rosea. Long-tailed Titmouse.

P. major. Great Titmouse.

$P$. coeruleus. Blue Titmouse.

$P$. britannicus. Coal Titmouse.

$P$. palustris. Marsh Titmouse.

L. cristatus. Crested Titmouse.

\section{General Description.}

Long-tailed Trtmouse.-Forehead and crown white; sides of the crown, mape, and upper part of the back black; lower back and scapulars rose coloured; wings blackish brown, the inner quills margined with white; tail long, gracluated, black, the outer feathers margined and tipped with white; under parts white, the flanks tinged with rose. Total length about 6 in., wing $2 \frac{1}{2}$ in., tail $3 \frac{6}{10}$ in. The female has the head more marked with black, and the young are duller in colour and lack the rose colour in the plumage.

Graat Titurouse.-Crown, chin, throat, and a band on the sille of the neck bluish black ; back yellowish olive; wings blackish brown, externally with paler margins; wing coverts blue grey with white tips; tail slate grey, the outer feathers tipped and margined with white; cheeks white; uncer parts yellow with a black central streak. Total length about $5 \frac{4}{5}$ in., wing 3 in., tail $2 \frac{1}{2}$ in. The female is rather duller, and the young have the cheeks tinged with primrose yellow. 
Bude Timrodse.-Crown blue, encircled by a white band; cheeks white; chin, a band encircling the white cheeks and one passing through the eye to the mape, blackish blue; back yellowish green; wings and tail blue; under parts sulphur yellow with a blue black central streak; bill black; legs blue grey. Total length about $4 \frac{1}{2}$ in., wing $2 \frac{6}{10}$ in., tail 2 in. The female scarcely differs from the male, and the young have the blue much duller in tinge.

Conl Titmouse.-Clown and nape bluish black; cheeks, sides of the neck, and a patch on the nape, white; back greyish olivaceous; wings and tail brown, the wings crossed by two white bands; throat black; rest of under parts white, washed with fawn on the flanks and belly; bill, legs and feet, dark brown. Total length about $4 \frac{1}{5}$ in., wing $2 \frac{3}{10} \mathrm{in}$, tail $1_{10}^{\frac{7}{10}} \mathrm{in}$. The female is rather duller in colour, and the young more so, and these latter have the nape patch, cheeks, and under parts washed with sulphur yellow.

Marsh 'l'itmouse.-Crown, nape, chin, and throat black; cheeks dull white; back olivaceous brown; quills and tail ashy brown, with paler external margins; under parts dull white, the flanks washed with buff; bill black; legs and head grey. Total length about $4 \frac{3}{5}$ in., wing $2 \frac{1}{2}$ in., tail $2 \frac{1}{4}$ in. The female resembles the male, but the young are duller and browner in colour.

Crested Titmouse.-Feather on the crown elongated, forming a conspicuous re-curved crest; black in colour, tipped with greyish white; sides of head and neck greyish white; a narrow line of black passes through the eye to the nape, and two bands of black cross the sides of the neck; throat also black; back, wings, and tail brown; under parts dull white; flanks warm buff. Total length about $4 \frac{1}{2}$ in., wing $2 \frac{1}{2}$ in., tail 2 in.

\section{When, where, and in what numbers found.}

Long-tailed Tit.-Resident throughout Great Britain and Ireland; less commonly distributed in Scotland than in England. Great Tit.-Resident throughout British Isles. Blue Tit.-Resident throughout British Isles; common everywhere. Coal Tit.-Resident throughout British Isles, but nowhere so abundant as the two preceding species. Marsh Tit.-Resident in England and Wales, rare in Scotland, but does not extend to Ireland.

Crested Tit.-Not uncommon in some of the old pine forests in Scotland, but of rare occurrence in England, and of doubtful occurrence in Ireland.

\section{Food.}

Insects, grubs, and seeds. The Long-tailed Tit is almost, if not quite, insectivorous. The other Titmice vary their diet more with seeds-the seeds chiefly of destructive weeds, and to a small extent they also feed on berries.

\section{Characteristics.}

The various peculiarities of these five Tits are dealt with and contrasted in Paragraph VII.

\section{Protection.}

Wild Birds Protection Āct, 1880.-These birds do not appear in the Schedule, but (1896) have been added to it in the following counties :-

Long-tailed Tit,-England : Lancaster, Buckingham, West Suffolk. Wales: Brecon. Scothand : Berwick.

Blue Tit.-Scothand : Berwick.

Coal Tit.-England : Buckingham, West Suffolk. Scotrand : Berwick.

Marsh Tit.-Enaland : Buckingham, West Suffolk.

In these Counties any owner, occupier, or other person taking, killing, etc, any of the specified Tits during close season, ${ }^{*}$ or possessing or selling one of them after 15th March, is liable to a penalty of $\mathfrak{E} \mathrm{L}$ for each bird. Elsewhere all Tits are protected during close time, except with regard to owners and occupiers of land.

* Generally from 1st March to 31st July; but in some counties from 1st February to 31st August in each year. A further period may be obtained through the Act of 1896. 


\section{Wild Birds Protection Act, 1894.-The eggs are protected (1896) in the following Counties *}

Long-tailed Tit.--Enalann: Leicester; Metropolitan Police District, including London and Middlesex; Warwick; West Suffolk; Worcester. Wales: Brecon. Swotlasd: Berwick. Blue Tit.-Scotland: Berwick.

Coal Tit.-Enguand : Leicester; West Suffolk. Scotrand : Berwick.

Marsh Tit.-England : Leicester; Warwick; West Suffolk; Worcester. counties :-

The eggs of all species are protected in the specified breeding areas in the following

Eratand: Northumberland; Tork (East Riding); Cambridge; Chester; Norfolk; Suffolk; Devon; Essex; Kent; Isle of Wight.

In the above places any owner, occhipier, or other person taking ol destroying the exgs of the specified Tits is liable to a penalty of $£ 1$ for each egg.

Wild Birds Protection Act, 1896. - In addition to any penalty under the Act of 1880 the Court may now order any trap, net, snare, etc., used by the offender to be forfeited.

Long-tailed Tit.-This bird is protected throughout the whole sear in the County of

\section{Remarks.}

Five common species of Tomtits, all original and delightful in their own little wars, abound in our woods, hedgerows, and gardens. The largest is the Grent Tit or Oxeye, with its noticeable yellow and black markings; the smallest, the delightful little Lons-tailed Tit. The brightest coloured is the Blue Tit, with its blue markings, whilst the Coal Tit and the Marsh Tit are the most soberiy attired. The sixth species, the Crested Tit, which is also plainly marked, is, as above stated, rare in England. $\dagger$

The wings of these mites of birds are, fortunately, too small to be of use to the "feathered" woman. Fortunately also, as the Tomtit flies rather in families than in flocks, the farmer or gardener who, under the erroneous impression that the birds bave come to rols him of his seed or of his fruit, may wish them ill, seldom considers them worth a charge of powder and shot.

Hence these Tontits, living a fairly blameless life, are little disturbed in their busy and restless existence, and are able to bring up their large families in comparative peace. Lively, acrobatic, fearless, pugnacious, restless, ormamental, they add much to the interest and the attractiveness of our country life. Indeed, it is this wealth of bird life that makes the wreat distinction between our English and the Continental woods and hedgerows; and which, if the farmers, gamekeepers, and gardeners would but appreciate it, does so much to lieel' down noxious insects and other pests.

The Tomtits clearly come within the category of birds that should be protected. Absolutely and entirely harmless I do not assert then to be. But it can be conficently stated-on. the authority of such naturalists as St. John, Yarrell, Lilford, Stevenson, Ancuilliviar, ame others, reinforced by the observation of anyone who takes the tronble to watch their wars--that the good they accomplish far, and very far, ontweighs any incidental harm they mity do. And, indeed, any harm they do is mostly incidental, and done without malice frepense.

The Titmouse bas a bill adapted both for soft and hard food, to the eonsumption of insect and of seed alike. Its food, tiking the Tomtits as a class, and without drawing invilinus, anl therefore perhaps dangerous, distinctions between the different species, consists primitrily wl insects and their eggs, of grubs, of caterpillars, of spiders, and the like; and the mumber w these the will consume in a day, especially when rearing their young, is almost increnlible.

In the second degree their food consists of seeds and fruits of tree, shrub, anil jilant; and, doubtless, they do, from time to time, consume seeds and grain at which they hiul hetter have drawn the line.

* It is expected that other counties will before long obtain similar orders of protection under the Act of 1894 .

+ Besides these six, two other Titmice are rare visitants with us, viz.; Acredula caudata, the Scandinavian Longtailed Titmouse, which differs in that the adult bird bas the entire hed and nape pure white; and Parus ater, the Continental Coal Titmonse, which las the back slate grey insteat of olive grey. The Bearded Reedling, Panurus biarmicus, is commonly supposed to be a Tontit, but in fact does not bilong to that family. Formerly it was fairly common in the "Bruad " Country, but is now, alas! nearly extinct. 
But much of their supposed fruit-destroying propensities are due, it is almost certain, not to any desire to dis-bud a fruit tree or to rob an orchard, but because the particular bud or fruit in question already conceals a canker. It is this hidden grub which the Tomtit desires-a noxious insect, though to him a delicacy, and which, if allowed to live, would not only destroy the particular bud or fruit, but might be the progenitor of further and unlimited destruction.

Similarly, their inconvenient and disordering investigations of thatch and straw are, we may charitably believe, dictated by a search for concealed insects, and not by desire for depredation nor by love of destruction. The slaughter of Titmice by farmer or gardener is, as has been well said, "an act of economical suicide."

The Tomtits are easily distinguishable in our woods. They all possess much the same sharp little note or twitter; they are all endowed with more or less the same restless disposition. They all have the same sudden, floppy, flappy, undulating flight; and, ever on the move in search of food, they delight in the same agile acrobatic movements. The Blue Tit is, perhaps, the most attractive. Perky, impudent, active, graceful, and beautifully coloured, it is a very charming sight to see a Blue Tit, or, better still, a lately fledged family, clinging, mostly head downwards, to the slender

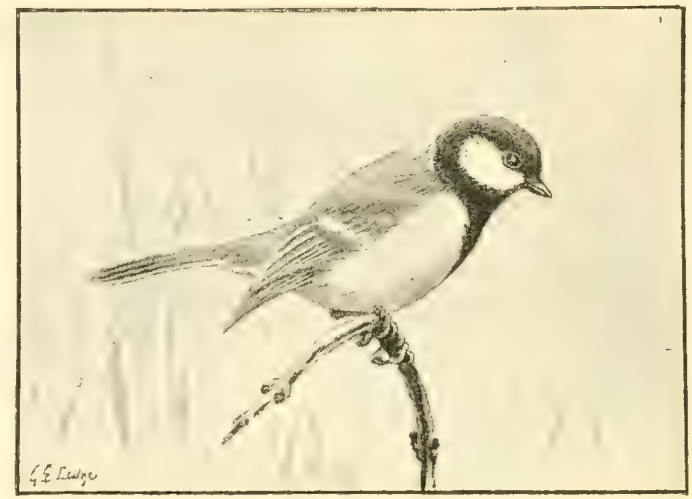

GREAT TIT. and waving boughs, rapidly examining the under side of each leaf and the interior of each crevice in the bark for the food they lore. The boldest, the noisiest, the most strikingly marked is the Great Tit. The Coal and Marsh Tits, less brightly coloured and less visible to the eye, are nevertheless noticeable through their unceasing activity. The smallest, the fluffiest, the most delicate lookingthough, constitutionally, perhaps the strongest of all-is the Long-tailed Tit, with its comically long tail. It is a real delight to watch a large family - and the families reared in the marvellously constructed nest are always large-wending its way leisurely through a wood. They travel from tree to tree, fluttering and conversing in the foliage overhead. At one moment all the members of the family are collected on a bough; the next, led by one more adventurous than the rest, off they all dart together to another tree, as though impelled by a simultaneous idea ; there, ever twittering, the search and re-search for insects in leaf and twig is renewed. At night, it is said (though I have never seen it myself) that the whole family, seeking warmth, squeeze together until they form one fluffy ball of feathers.

In two ways these little birds (other than the Long-tailed Tit, which is not to be tempted by human artifice) can be watched to great advantage.

A bowl filled with maize, hemp, or corn (unless, indeed, the offer of seeds of this description may be thought to be weakening for their morals, as tending to bring on a craving for forbidden food !) may be hung up near house or cottage ; or a lump of fat, a meaty bone, or a cocoanut be tied to a stick. Before long the Tomtits of the neighbourhood, attracted to the food, will, their shyness once overcome-and shyness is not their weak point-spend the livelong day darting backwards and forwards to the tempting morsel. Thus can their idiosyncrasics be watehed and noted.

The Marsh Tit-who, it must be confessed, is very fond of sceds-darts down and is off agrain, taking away the seed to be dissected and devoured in security. Neither does the Coal Tit care to prolong its stay. But the Great Tit will discuss his food on the spot, and, in full view, leisurely hammer away at his seed till he succeeds in extructing the kernel; and the Blue Tit, though with more haste and hurry, more jerks and twitterings, does the same.

Another effective plan of cultivating their acquaintance, where circumstances permit, is to nail nesting boxes up against the trees. These boxes should be about thirteen inches in 
length, by four inches broad and deep. They should hare easily lifting lids, and at one enr a small hole should be eut. The hole must be small to prevent linge birels and squirrels from intruding or robbing. The box, for convenient observation, should be nailed some five feet from the ground. No nesting material shoukd be inserted; every shred of it will be ejected before the real nest is begum. The box sbould be placed in position sume montlis before the nesting season, so that it may get weatherworn, and so that the birds mat become accustomed to its presence.

The nesting box was suggested ly the nesting places sometimes selecterl by the Tit amit other birds, such as wooden pumps, cross road letter hoxes, and the lile; and certainly it is most popular with some classes of birds, Tomtits especially.*

In these boxes the Tomtits industriously construct their mossy, feathery, furry nests, and lay their numerous clutch of brown-spotted white eggs, which are most carefully covered out of sight when business or pleasure calls them away from home. In due time the downy little chicks arrive, and, as they grow and fatten and put on feathers, the nest becomes unduly congested; and often the young broods have to be content to live in layers, one set on the top of another. This is especially the case with the Blue Tit, which rears the largest broods. It is always a mystery how the unfortunate and over-driven parents manage to know each time whose turn it is to be fed, for each and every chick is always clamorous for food. Perhaps, as the top layer is fed, it sinks by the force of gravity to the bottom, and the lighter and unfed layer comes to the top!

These nest boxes bring out again the difference of disposition. The Coal Tit and the Marsh Tit nervously fly off the nest at the approaching footstep, and twitter tremulously around while the precious box is being examined. The Blue Tit sometimes, the Great Tit nearly always, will remain sitting on the eggs or covering the young if the lid of the box be gently opened. The Blue Tit, anxiously and attentively watching for any further sign of danger, sits silent, till, the strain becoming

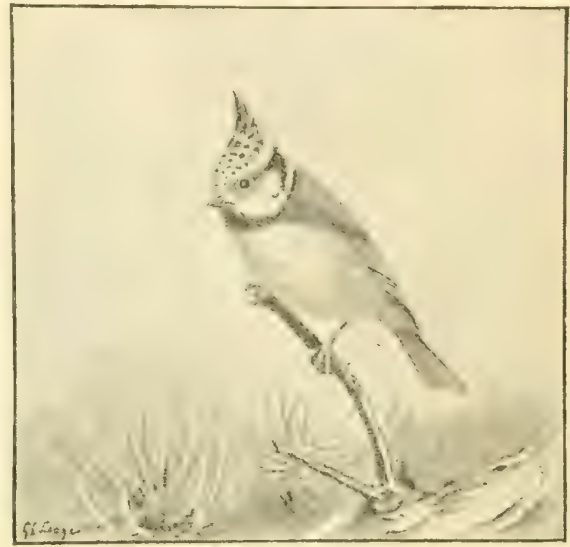

CRESTED TIT. more than she can bear, off she flies. The Great Tit, on the other hand, will even allow itself to be stroked; but it keeps a stern eye on the intruder, and relieves its feelings the while by audibly swearing.

A box full of little Blue Tits, just ready to fly, is as pretty a sight as one could wish to see; and for days after they leave the box the family flutter around its immediate neighbourhood.

All the Tits nest in holes or boxes as abore described excepting the Long-tailed Tit, which builds a beautifully constructed oval nest, with a small hole on the side, composed of lichens, moss, spiders' webs, etc., closely felted together, and well lined with feather's or hair. The nest is placed in a bush, creeper, or ivy, or else in the branch of a tree-sometimes low down and at others high up. They las from eight to twelve white eggs, spotted with reel.

I commend the Titmice to the observation of all lovers of birds, and their protection to all those interested in gardening or agriculture.

* Besides the four Tomtits above mentioned, we hare constantly building in our small boxes the Redstart, the uninvited and ubiquitous Sparrow, and the sleek and cute-looking Nuthatch, who, for greater security, clays down the lid of the bor. Occasionally eren the Wryneck condescends to come; nesting late, he mostly chooses a box in which a Tomtit has already built and hatched, incontinently ericts all the joung Tomtits, kicks out all the nest, and lays his own delicate and transparent white eggs on the bare boards.

Pamphlets on the general question of Protection of Birds may also be obtained from the Society's Publishing Department, Knowledge Oifice, 326, High Holborn, WT.C., or of MIr. F. E. LEMox, IIum. Sec., Hillcrest, Redhill, Surrey. 


\section{Soriety for the 羽rotection of zirng.}

\section{EDUCATIONAL SERIES.}

No. I.-OWLS, by Montagu Sharpe, J.P., D.L.

No. 2.-WOOdPECKers, by Sir Herbert Maxwell, Bart., M.P.

No. 3.-STARLing, by O. V. Aplin, F.L.S., M.B.O.U.

No. 4.-SWALlOWS, by Thomas Southwell, F.Z.S.

No. 5.-KINGFiSher, by Sir Ediward Grey, Bart., M.P.

No. 6.-OSPREY, by J. A. Harvie-Brown, F.R.S.E., F.Z.S.

No. 7-DIPPERS, by W. Lock Mellersh, B.A.

No. 8.-NightJAR, by Montagu Sharpe, J.P., D.L.

No. 9.-TItTilaE, by Sydney Buxton, M.P.

No. IO.-KESTREL, by Rev. J. E. Kelsall, M.A.

No. it.-PLOYeRS, by Joseph A. Pease, M.P.

IN COURSE OF PREPARATION.

No. .--TERINS, by Thomas Southwell, F.Z S.

No. .WAGtails, by W. Warde Fowler.

No. -ChoUgh, by J. A. Harvie-Brown, F.R.S.E., F.Z.S.

No. -GOLDFINCH, by W. H. Hudson, C.M.Z.S.

No. -JaY, by John Cordeaux, M.B.O.U.

No. -GULlS, by Howard Saunders, F.L.S., F.Z.S.

No. -- $\quad$ by Wm. Eagle Clarke, F.L.S., etc,

No. -.SKUAS, by T. E. Buckley, M.A, F.Z.S.

And Wild Birds Protection Acts and Orders, I880 to 1896 , with Explanatory Notes, by F. E. Lemon, M.A., LL.B.

Copies of the above Series may be obtained from the Society's Publishing Department, "Knowledge" Office, 326, High Holborn, W.C., or from the HoN. SEC., Mrs. F. E. Lemon, Hillcrest, Redhill, on the following Terms:-Post Free: 3 Copies of any one number of the Series, 1d.; I Dozen, 3d. ; Ioo, 1s. 6d. Assorled Packets: I Copy of any six numbers, 2d. ; I Copy of any twelve, or 2 Copies of any six numbers, $4 \mathrm{~d}$.; or fifty Assorted numbers, $1 \mathrm{~s}$.

Special Terms for Larger Quantities, and to County Councils, the Constabulary, Schools, JANUARY, 1897 . and Educational Bodies.

The Society's Publishing Office, hnowledge, 326, High Holborn, London, W.C. 


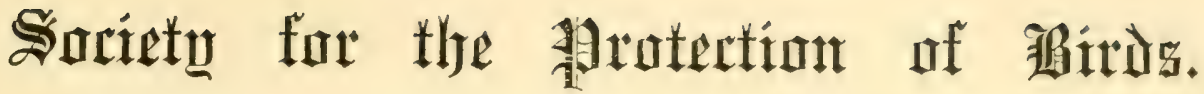

EDUCATIONAL SERIES. Edited by H. E. DRESSER, F.L.S., F.Z.S.

\section{No. I0.-KESTREL.}

By the REv. J. E. KELSALI, M.A.

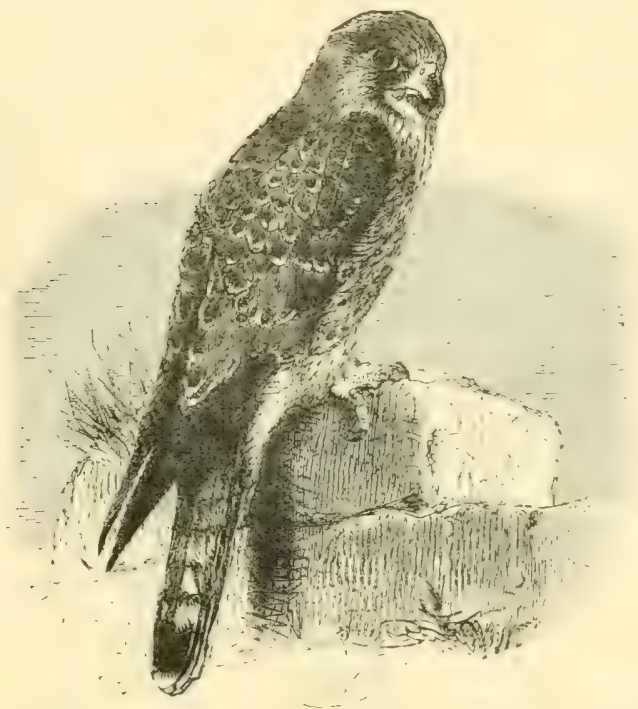

KESTREL,

\section{Name.-KESTREL or WINDHOVER.}

Fimily-Litlonidu:

Genus-Firlco.
Faleo timnuniulus.

\section{Genera] Description.}

Adult male: Head, neck, lower back, and tail, bluish grey, the latter tipped with white; below a broad black band; back, pale chestnut, with small black spots; under parts buff, streaked and spotted with black; legs and feet yellow. Length, 13 inches. liemale: Upper parts reddish brown, barred with black; sereral narrow bands of hlack on the tail, with a broad one near the tip. Very old hens partially assume male plumage, and have more or less blue on the rump and tail. Length, 15 inches. The young resemble the female, but are somewhat lighter in colour. (Howard Saunders.)

Illustration by Joseph Wolf, from "British Birds in their IIaunts" by lind permission of the Society for Promoting Christian Knowledge. 


\section{When, where, and in what numbers found.}

Found in all parts of Great Britain at all seasons, except that it migrates as a rule from the northern districts of Scotland in winter. (Howard Saunders.)

We sometimes receive an immigration from Northern Europe in autumn.

\section{Food.}

Principally mice and insects, rarely small birds.

\section{Characteristics.}

A small hawk, with a red back, and hovering flight.

\section{Protection.}

Wild Birds Act, 1880.-This bird does not appear in the Schedule, but has been added in the following Counties:-

ENGLAND :-Durham ; Lancaster--Bedford; Buckingham; Chester; Derby ; Lincoln (Kesteven and Lindsey); Northampton; West Suffolk-Devon: Hertford ; Isle of Wight: Kent; Metropolitan Police District (including London and Middlesex); Somerset: Wiltshire.

Scotlaxi :-Aberdeen, Dumfries, Elgin, Haddington, Kirkcudbright, Wigtown.

In these counties any owner, occupier, or other person taking, killing, etc., a kestrel during close season, * or possessing or selling a kestrel after i $5^{\text {th }}$ March, is liable to a penalty of $\ell_{\text {I }}$ for each bird.

Wild Birds Act, 1894.-Its eggs are protected at present (1896) in the following counties : $†$ -

ENGLAND :-Cumberland; Durham; Northumberland; Westmoreland ; Yorks, East Riding (specified area); Bedford; Chester; Derby; Gloucester; Leicester ; Lincoln ; (Kesteven and Lindsey); East Suffolk (specified area); Northampton; Stafford ; Norfolk (specified area); West Suffolk; Warwick ; Worcester; Devon; Essex (specified area); Hertford; Kent; Metropolitan Police District (including London and Middlesex) ; Isle of Wight.

WALES :-Brecon.

ScotlaND :-Aberdeen; Dumfries ; Elgin; Haddington ; Kirkcudbright ; Linlithgow, Nigtown.

Any owner, occupier, or other person taking or destroying a kestrel's egg in these counties is liable to a fine of $\mathcal{E}_{\mathrm{I}}$ for each egg.

Wild Birds Act, 1896. - In addition to any penalty under the Act of 1880 , the Court may now order any trap, net, snare, etc., used by the offender to be forfeited.

The Kestrel is protected throughout the whole year in the County of Middlesex.

* Generally from Ist March to 3ISt July; but in some counties from Ist February to 31 st August in each year. A further period may be obtained through the Act of 1896 , as in Middlesex.

+ It is expecterl that other counties will before long obtain similar orders of protection under the Act of 1 S94. 


\section{Remarks.}

Poor Kestrel! One is sometimes inclined to write him down "the last of British Hawks!" IIell, not quite so bad as that. The Sparrow Hawk is still a common bird, and the Peregrine, the Merlin, the Hobby, and the Buzzard may be found in certain faroured spots; but iin nine cases out of ten the only hawk that we are sure to meet in our country walk is the Kestrel, whereas there was once a time when the Peregrine dwelt in every cliff, and in many steeples too, when the Harriers beat over every field and marsh, the Kite harried erery farmyard, and the Buzzard wheeled and screamed over every wood.

And now none are left to the casual lover of nature except the Kestrel and the Sparrow Hawk. Ind as the Sparrow Hawk is a sad poacher, the first thing to be done on behalf of the Kestrel is to make sure that every game preserver and every keeper knows the two birds apart, for in some places the name Sparrow Hawk is persistently applied to both species. In fact, to quote the late Lord Lilford, "it is much to be wished that all who are interested in game should be impressed with the difference between the Sparrow Hawk and its less destructive relations."

The Kestrel, then, is the red hawk that hoyers; the Sparrow Hawk is the blue hawk that dashes. The Sparrow Hawk sweeps along under the hedge, or round the hay-rick, or along the side of the copse, and pounces on some greedy flock of quarrelling sparrows, or on the scattered brood of partridge or pheasant. The Kestrel hangs almost motionless in mid-air, as though suspended from the sky by a thread, looking down with keen eyes for mice and grasshoppers on the ground below, and suddenly dropping upon its prey. There are one or two other British hawks which occasionally hover in a similar manner, but they are much larger, and. of course, much rarer birds.

We must not expect to obtain protection for the Kestrel unless we can prove that he seldom or never destroys game-birds. The greater number of naturalists agree in declaring that his principal food consists of mice-that is field mice and voles, destructive little creatures which lay waste miles of country when they are allowed to increase without restraint. As the Swallows and the Nightjar divide the day and night in their ceaseless pursuit of insects, so the Kestrel relieves the Owls in the work of thinning the hosts of mice.

But the Kestrel does not despise insects, and is known to devour quantities of grasshoppers, beetles and their grubs, especially dor-beetles and cockchaters, crane-flies (daddy-long-legs), and even worms.

Frogs and slow-worms also occasionally afford him a change of diet; and little birds? What, never? Well

That observant and accurate Devonshire naturalist, Col. Montagu, declared that he never found a feather in the stomach of this bird, which would alone be enough to prove that such a diet is very exceptional.

But perhaps the best and fairest summary of this vened question is contained in the following quotation from the "Field and Covert Shooting "volume of the Badninton Library, this particular extract being from the pen of the Hon. Gerald Lascelles, Deputy Surveyor of the New Forest, who writes, of course, from the point of view of the sportsman and not of the sentimentalist :-

"As a rule there is no more harmless bird than the common Kestrel or Windhover, commonly confused by ignorant and unobservant keepers with the Sparrow Hawk, and ruthlessly destroyed by them. Very different are the habits of the two species, and while little or no good can be credited to the Sparrow Hawk, the Kestrel may lay claim to being one of the farmer's best friends in existence. Its principal food consists of the common field mousc, and of the numerous beetles and larva which it can glean from the face of the land. Grasshoppers are a favourite food, and it has frequently been seen to destroy the slow-worm; while there are also instances on record of its taking the adder. Very rarely, indeed, does it seize a bird of any kind, and then only if they are crouching on the ground. But its weak feet and lack of courage render it quite unable to hold even a three-parts grown partridge. There 
is one occasion, and one only, when the Kestrel should be killed without mercy. It is when an old bird, having a brood at home to bring up, finds out the coops where a number of pheasants or partridges are being reared. Having once discovered with what ease she can take any of the tiny, half-tame, wholly foolish little creatures, she will return again and again til she has destroyed the whole lot. Let that Kestrel be killed without an hour's delay, but let not that be made an excuse for killing in future every individual of a species which does so much good.

"All animals resemble human beings in one respect, namely, in their proneness to contract evil habits.

"The unfortunate bird that had taken to paying visits to the coops has paid for its iniquities with its life; but it does not follow that every other Kestrel need do the same. As an instance in point the following fact may be mentioned:-

"In I $S S_{3}$ about three hundred pheasants were being reared by a keeper in a field partly surrounded by a wood of ancient trees of considerable extent. In this wood were the nests of no less than six pairs of Kestrels, none of which was more than three-quarters of a mile from the coops. The keeper had been strictly ordered not to molest the Kestrels in any way, and ere long he came with a piteous tale as to the birds which had been carried off before his very eyes by those hawks.

"He was at once ordered to conceal himself with his gun, close to the coops, and to shoot any hawk he found in the act of skimming down to them.

"Ere the day was out he triumphantly produced both the male and female of a pair of Kestrels which he had shot in the very act of taking his birds, and wanted to know "what we had to say to that,' and if we still believed that 'Kestrels did no harm?' 'Very well,' we said, 'keep your gun handy, and shoot any hawk you can catch within range of your crops ; but let them come to you-do not go to them.'

"Not another Kestrel was killed that year, though the other five pairs all reared their broods, and their nests were no further off than that of the pair which fell into bad habits, and died in consequence.

"Let the keeper use his discretion, then; and while he will do well to kill any individual Kestrel that does harm to him, he should be restrained from killing down too closely such useful birds."

[For permission to copy this lengthy extract, we are much obliged to the publishers, Messrs. Longmans, Green, \& Co.]

The Kestrel seldom, if ever, builds a nest, but either makes use of the former dwelling of a Crow, Magpie, or Wood Pigeon, or else lays its eggs in a hole in the cliff, (juarry, or chalk-pit, or a church tower or hollow tree. (Howard Saunders.)

From the top of a high cliff we may often look down on the flight of this bird, and recognize it by its red back.

The eggs are thickly mottled with rich reddish brown. 'The usual note is a loud "klee, klee, klee, klee."

The late Rev. C. A. Johns, author of "British Birds in their Haunts" (S.P.C.K.), wrote that he had often noticed that Chaffinches and other small birds showed no dread of a tame Kestrel in a garden, but fearlessly perched in the same tree with it.

Educational Series.-No. 1.-OWLS. No. 2.-WOODPECKERS. No. 3.-STARLING. No. 4.-SWALLOWS. No. 5.-KINGFISHER, No. 6.-OSPREY. No. 7.-DIPPERS. No. 8.-NIGHTJAR. No. 9.-TITMICE. No. 10.-KESTREL. No. 11.-PLOVERS.

Others in course of preparation.

Copies of the ahore mav be obtained from the Society's Publishing Department. Knowledile Office, 326, High Holhorn, IV.C., or from the Hon. Sec., Mrs. F. E. LEMoN, Hillerest, Redhill, on the following terms:--Punt free: Three copies of any one number of the Series, 1d; one dozen 3d.; 100, 1s hd. Ascorted packets, one copy of any six numbers, 2d, one copy of any twelve, or two copies of any six numbers. $4 \mathrm{~d}$; or 50 assorted numbers, Is. special terms for larger quantities to County Councils, the Constabulary and Schools. 


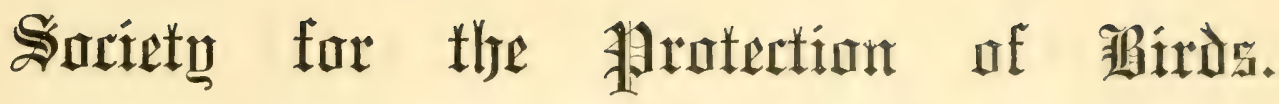

EDUCATIONAL SERIES. Edited by H. E. DRESSER, F.L.S., F.Z.S.

\section{No. II.-PLOVERS. \\ By JOSEPH A. PEASE, M.P., \&c.}

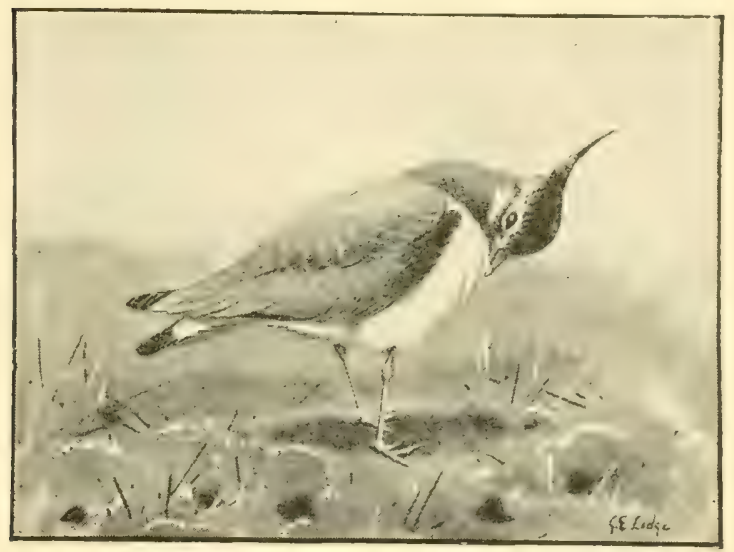

LAPIVING.

\section{Name.-PLOVER.}

Family-Edicnemide.

Genus 1.-Edicnemus. $\quad$ E. scoopax. Stone Curlew, or Norfolk Plover.

Family-Charadriida.

Genus 2.-Charadrius.

C. pluvialis. Golden Plover.

Genus 3.-Squatarola.

S. helvetica. Grey Plover.

Genus 4.- Egialitis.

E. hiaticula. Ringed Plover.

E. curonica. Lesser Ringed Plover.

E. cantiana. Kentish Plover.

Genus 5.-Eudromias.

E. morinellus. Dotterel.

Genus 6.-Vanellus.

V. vulgaris. Lapwing, or Pewit.

II. General Description and Proportion in inches.

Stone CURLew,-Upper parts, greyish brown, varied with blackish brown : under parts, white. streaked with dark brown; wings, blackish, with a light band across them, and the two outer quills banded with white ; tail, light brown, mottled with dark brown, and tipped 
(the two central feathers excepted) with black; bill, greenish yellow, tipped with black ; legs and eye, yellow. Total length, $13 \frac{1}{2}$ inches ; wing, 9 inches ; tail, $4 \frac{1}{2}$ inches.

Golden Plover.-Upper parts, blackish brown, spotted with yellow; under parts, black, the sides of the neck bordered with white; wings, blackish; axillaries, white; bill and legs nearly black; eye, brown. Total length about $10 \frac{1}{2}$ inches; wing, $7 \frac{1}{2}$ inches ; tail, 3 inches. In winter the under parts are white, the breast mottled with greyish brown.

Grey Plover.-Differs from the Golden Plover in having the upper parts white, barred with black and brown; in having a small hind toe; and the axillaries are black.

Ringed Plover.-Forehead and a stripe behind the eye, white; the forepart of the crown, the sides of the head, and a broad collar round the lower neck (much broader on the breast), black ; rest of the upper parts, brown ; and of the under parts, white ; wings, blackish brown, with a narrow bar; outer tail feathers, white, the rést brown, tipped with white; bill, yellow, tipped with black; legs, orange yellow. Total length, $7 \frac{3}{4}$ inches; wing, $5 \frac{1}{2}$ inches; tail, $2 \frac{1}{2}$ inches.

Lesser Ringed Plover.-Differs from the Ringed Plover in being much smaller; the shafts of all the primaries are dusky, except the outer one, which is white; and the upper parts are paler in colour. Total length, $6 \frac{1}{2}$ inches; wing, $4 \frac{1}{2}$ inches ; tail, $2 \frac{1}{4}$ inches.

Kentish Plover.-Forehead, and a line above each eye, white; lores, a stripe behind the eye, forecrown, and a patch on each side of the neck, black; crown and nape reddish brown; rest of the upper parts brown, and of the under parts, white; legs and feet black. Total length, about $6 \frac{3}{4}$ inches; wings, $4 \frac{1}{4}$ inches ; tail, $1^{\frac{3}{4}}$ inches. The female is duller in colour, has no black on the crown; and the neck patches are brown.

DoTTEREL. - Crown and nape black, bordered by a broad white stripe ; forehead mottled ; upper parts ashy brown; chin and throat whitish; breast ashy brown, marked with black; a white band across the breast; lower breast and flanks rich chesnut red; belly black; under tail covert white; axillaries grey; bill blackish; legs yellowish brown. Total length, about 9 inches; wing, 6 inches; tail, $2 \frac{3}{4}$ inches.

LAPWING.-Head crested; crown, throat, and breast, black, with greenish or purplish gloss; sides of the neck, and rest of under parts, white; upper parts metallic green, glossed with purple and copper; tail white, tipped with black; upper and under tail coverts reddish buff; bill black; legs and feet reddish brown. Total length, about I $2 \frac{1}{2}$ inches ; wing, 9 inches ; tail, $4^{\frac{3}{4}}$ inches.

\section{Where, when, and in what numbers found.}

The Stone Curlew is fairly common in suitable localities in England, rare in the north, and of uncommon occurrence in Scotland and Ireland. It arrives in April and leaves in October, but some few remain in mild winters.

Golden Plover is a common bird, especially in winter, throughout Great Britain, and breeds in south England in elevated localities, and in Scotland and Ireland.

Grey Plover is only a winter visitant to our coasts, and does not breed here, but at that season is not uncommon. 


\section{$\left[\begin{array}{ll}3 & ]\end{array}\right.$}

Ringed Plover is a common and resident species on our coasts, and inland lakes, and on migration on the banks of rivers.

Lesser Ringed Plover is of very rare occurrence in England, and has not been met with in Wales, Ireland or Scotland. A small form of the Ringed Plover has often been mistaken for it.

Kentish Plover is found in small numbers on the coasts of England, but does not winter with us, is a very rare visitant to Ireland, and does not occur in Scotland. Formerly it used to breed not uncommonly on our Southern coasts, but has been nearly exterminated, chiefly by collectors.

DotTerel arrives in April and leaves us again in August or September, and breeds in greatly diminished numbers in the Lake districts and in Scotland, but is of rare occurrence in Ireland. It has been subject to great persecution by collectors, and owing to its feathers being held in esteem by anglers for dressing artificial flies.

LAPwing is common and resident throughout the British Islands, but appears to be more numerous in winter.

Besides the above, there are several other species which are met with only as rare visitants and are, therefore, not included. These are the Eastern Golden Plover (Charadrius fulvus) the Cream-coloured Courser (Cursorius gallicus), the Sociable Plover (Chettusiat gregaria), and the Killdeer Plover (Aigialitis vocifera).

\section{Food.}

All the above species feed on worms, beetles, insects of various kinds, shrimps, sandhoppers, small molluscs, etc., and are, therefore, not only harmless, but of considerable use.

\section{Characteristics.}

The Stone Curlew frequents chalk downs, open heaths, and sandy soil ; the Golden Plover the sea coast, moors, heaths, and ploughed fields, the last especially, in winter. The Lapwing is usually found on inland heaths and marshes, and in winter on cultivated land. The Dotterel frequents moorland, especially in elevated localities, and is partial to chalky soil, and the Kentish and Ringed Plovers frequent the sea coast, sandy dunes, and even inland lakes. Those that breed with us spread about in suitable localities during the breeding season, but on passige and in winter they collect in small family parties or flocks, and at that season almost all are more frequently to be met with on the coasts, where they are better able to find food. They nest on the ground; the Dotterel depositing three, but all the rest usually lay four eggs, and the young are able to run directly they leave the shell; and, when an intruder approaches. hide at once, and are not easily seen, as their colours assimilate so closely with the surroundings,

The note of all the Ringed Plovers and of the Grey and Golden Plovers is a clear loud whistle, and the Stone Curlew has a loud, shrill, call note, not unlike that of the Curlew.

\section{Protection.}

Wild Birds Protection Act, 1880.-These birds appear in the Schedule, which applic's to every county in England, Scotland, and Ireland. Any owner, occupier, or other person taking, killing, etc., a Plover during close season," or possessing or selling a Plover after 15 th March, is liable to a penalty of $\mathcal{E}_{\mathrm{I}}$ for each bird.

* Generally from Ist March to 3Ist July ; but in some counties from Ist Febiuary to $3^{\text {Ist }}$ August in each year. A further period may be obtained through the Act of 1896 . 


\section{$\left[\begin{array}{ll}4 & ]\end{array}\right.$}

Wild Birds Protection Act, 1894.--The eggs are protected in the following counties*:-

Stone Curlew.-England: Herts; Kent; Norfolk; West Suffolk. Scotland: Orkney.

Golden Plover.-England: Northumberland; Westmoreland. Scotland: Aberdeen; Elgin; Orkney. Ireland : Roscommon.

Ringed Plover.-England: Northumberland (Farne Island); Norfolk; Lincoln (specified area in Lindsey); Dorset (specified area). Scotland: Berwick; Dumfries; Elgin; Haddington; Kirkcudbright ; Orkney; and Wigtown.

Kentish Plover.-England : Kent.

Lapwing.-ScotLand : Aberdeent; Argyll (Isles of Islay, Colonsay, Coll, and Tiree); Dumbarton†; Dumfries†; Elgin; Kirkcudbright†; Orkney; Wigtown $\dagger$.

Dotterel.-England: Cumberland; Durham; Westmoreland. Wales: Brecon. Scotland : Dumbarton; Orkney.

The eggs of all species are protected in the breeding areas in the following counties :-

ENGLAND : Northumberland (Holy Island); York (East Riding)_-Cambridge; Chester ; Norfolk; East Suffolk-Devon; Essex; Kent; Isle of Wight. ScotLand : Orkney (whole county).

Any owner, occupier, or other person taking or destroying eggs of specified Plovers in above-named places is liable to a penalty of $\mathcal{L}$ I for each egg.

Wild Birds Protection Act, 1896. - In addition to any penalty under the Act, is8o, the Court may now order any trap, net, snare, etc., used by the offender to be forfeited.

\section{Remarks.}

Ornithologists have some difficulty in drawing a hard and fast line of demarcation between Plovers and some of their allies, and the respective degree of affinity is not fully determined. The list given here are birds which are either generally or occasionally recognized under the name of "Plover."

The Plover or Lapwing is also known by the names "Peewit, Puit, Peesweep, Wype, Teuchit, and Hornpie." Plovers can hardly be called migratory, as many remain throughout the winter, especially in the absence of frost and snow ; the majority, however, in hard weather, go south to North Africa, whereas others remain by the estuaries of rivers in the British Isles.

In February and March, numbers come from abroad, pair, and spread themselves over nearly the whole country. Their note is conveyed by the word "peewit" or "peaswit," from whence is derived two of the names by which they are popularly known.

Restless, watchful, and shy, these birds rarely approach either trees or houses, and even when roosting in the day, they keep a sentinel on the alert to warn the flock if any danger approaches. The designing ways by which they seek to decoy an intruder from their young are remarkable, the male being most clamorous, the female running some way from her nest or brood before venturing to excite attention by simulating lameness or an inability to fly. They run swiftly with their heads poked downwards, stopping suddenly at intervals, and in their

* It is expected that other counties will before long obtain similar orders of protection under the Act of 1894 .

t From 15 th April in each year. 
somewhat peculiar flight they proceed by a series of easy jurks, but with a rapid movement of the wings. The wings may be seen to be always outstretched on each side when the bird settles.

The Lapwings feed chiefly in the twilight or clear night, and restrict themselves wholly to animal food. Competent naturalists assert, by striking a foot they make the ground vibrate in a way to cause worms to come to the surface of the ground; the vibrations so caused are said to be similar to those made by a mole, the worm's natural enemy, and thus the worm is induced to come up to the surface to meet a no less deadly enemy. Of all birds the I apwing is, perhays, the farmer's best friend, it kills a variety of insects injurious to agricultural produce, such as slugs, wire-worms, caterpillars, turnip fly, and larvæ of various kinds. The number of eggs deposited is usually four, and these are placed in the nest with the small ends towards the centre, thus occupying the least possible space.

The Lapwing at one time was decreasing, but the Acts of 1872 , and of 1880 and I894 have done something to preserve this valuable bird. Care, however, should be taken that their numbers should not diminish by their eggs, which are estecmed as a delicacy, being too closely sought after for the table. To give some indication of the popularity of l'lorer's eggs, it may be stated that 800,000 eggs are annually imported into London from Friesland in Holland. The Norfolk Plover, Stone Plover, Stone Curlew, or Thick-knee, is most often found near the East Coast in Norfolk and Yorkshire, but is known in many other places, and in certain localities appears to be a regular summer visitant. They arrive about April and leave towards the end of September in flocks from four to seven, and migrate by night. They repair to water in the evening. They are naturally shy, but can be easily tamed. Their wild wail at night is rendered by the word "kroeet."

The Golden Ployer is frequently found on high ground throughout the British Isles, but it is especially numerous in Sutherland, Durham, Yorkshire, and the fen districts of Cambridge: Golden Plovers are both indigenous and migratory. Many arrive in this country in November, and disperse generally in February to breed on boss and undrained hills, but in frost and snow many leave for the Mediterranean basin, and others resort to the sea coast. I skilful imitation of their cry will bring them to you ; the note may be produced by a whistling sound most nearly' rendered by the word "tluwee-tluwee."

The Grey Ployer is not a common bird in Britain. When they migrate they do it in two long lines headed by one bird; the Grey Plover walks slowly, and with grace.

The Ringed Plover (also known as Stonehatch, Plover's l'age, and Scalark) is found on nearly all our coasts, especially by estuaries and creeks, and sometimes by inland lakes and ponds. It avoids the waves neatly by deviating just as much, and no more than is necessary, from its course, and thus, without allowing the waves to touch it, runs along the edge of the water. Flocks vary from a dozen to hundreds. The Little Ringed Plover is a very rare visitor to our land.

The Kentish Plover associates with Ringed Plorers, but keeps distinct in flight. Their nests contain, like those of all the other Plovers excepting the Dotterel, four eggs.

The Dotterel is to be found in certain lake districts, also on the Yorkshire wolds, and occasionally elsewhere. There are generally ten or twelve together. It migrates about ipril to breeding grounds in the north-to the Grampian hills and mountains in the north of Scotland. It returns again about the end of August, and stays till October or Norember. It is easily. trapped, hence the origin of its name, from the word "dote" or a "fool."

Educational Series, 3 copies, 1d.; 1 dozen, 3d.; 100, 1s. 6d., post free.

Pamphlets on the general question of Protection of Birds may also be obtained from the Societr's Publishing Department, Ĺnowledge Office, 326, High INolborn, W.C., or of Mrs. F. E. Lexos, Hon. Sec., Hillerest, Redhill, Surrey. 


\section{Soriete for the 羽rotection of birts.}

\section{EDUCATIONAL SERIES.}

No. I.-OWLS, by Montagu Sharpe, J.P., D.L.

No. 2.-WOOdPECKerS, by Sir Herbert Maxwell, Bart., M.P.

No. 3.-STARling, by O. V. Aplin, F.L.S., M.B.O.U.

No. 4.-SWALlowS, by Thomas Southwell, F.Z.S.

No. 5.-KINGFisher, by Sir Edward Grey, Bart., M.P.

No. 6.-OSPREY, by J. A. Harvie-Brown, F.R.S.E., F.Z.S.

No. 7-DIPPERS, by W. Lock Mellersh, B.A.

No. 8.-NightJAR, by Montagu Sharpe, J.P., D.L.

No. 9. -TITMICE, by Sydney Buxton, $M_{n} P$.

No. IO.-KestREL, by Rev. J. E. Kelsall, M.A.

No. i I.-PLOVERS, by Joseph A. Pease, M.P.

IN COURSE OF PREPARATION.

No. - - TeRnS, by Thomas Southwell, F.Z.S:

No. -Wagtails, by W. Warde Fowler.

No. -ChOUGH, by J. A. Harvie-Brown, F.R.S.E., F.Z.S.

No. -GOLDFINCH, by W. H. Hudson, C.M.Z.S.

No. - - JAY, by John CoRdeaux, M.B.O.U.

No. -GULls, by Howard Saunders, F.L.S., F.Z.S.

No. - - by Wm. Eagle Clarke, F.L.S., etc,

No. .-SKUAS, by T. E. Buckley, M.A., F.Z.S.

And Wild Birds Protection Acts and Orders, I880 to I896, with Explanatory Notes, by F. E. Lemon, M.A., LL.B.

Copies of the above Series may be obtained from the Scciety's Publishing Department, "Knowledge" Office, 326, High Holborn, W.C., or from the HoN. SEc., Mrs. F. E. Lemon, Hillcrest, Redhill, on the following Terms:-Post Free: 3 Copies of any one number of the Series, 1d.; I Dozen, 3d. ; Ioo, 1s. 6d. Assorted Packets: I Copy of any six numbers, 2d. ; I Copy of any twelve, or 2 Copies of any six numbers, 4d.; or fifty Assorted numbers, Is.

Special Terms for Larger Quantities, and to County Councils, the Constabulary, Schools, JANUARY, 1897 . and Educational Bodies. 


\section{Suriety for the Arotertion of 解irds.}

EDUCATIONAL SERIES. Edited by H. E. DRESSER, F.L.S., F.Z.S.

\section{No. 12.--TERNS, or SEA SWALLOWS.}

By THOMAS SOUTHIVELL, F.Z.S.

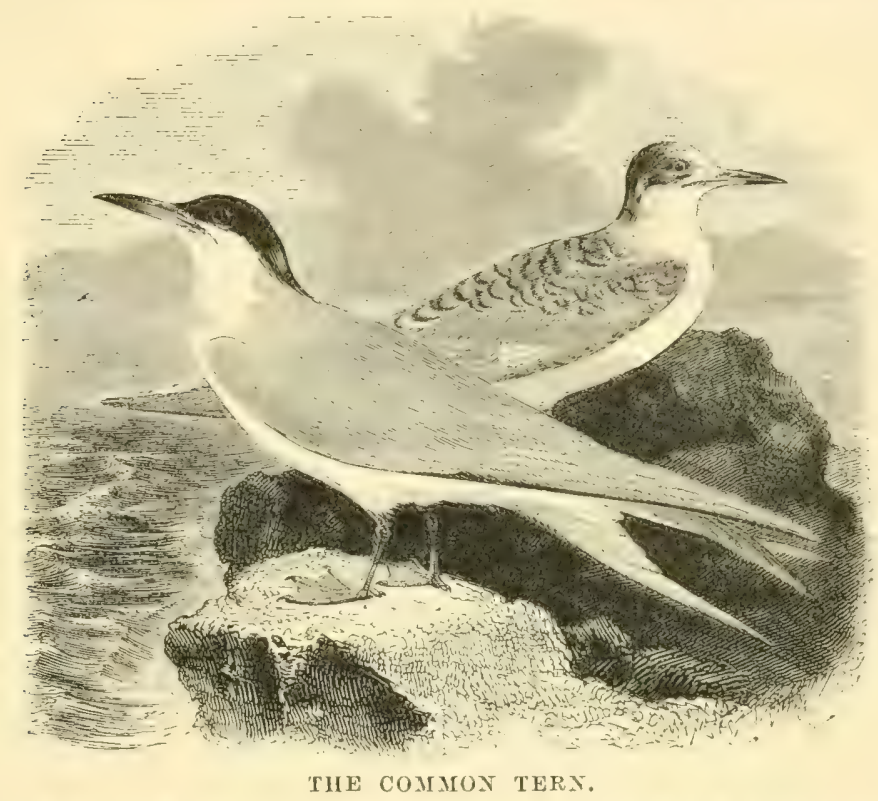

\section{Names.-TERNS, OR SEA SWALLOWS.}

Family-Luridx.

Sub-Family-Sterninæ or Terns.
Genus-Sterna.
S. fuviatilis.
Common Tern.
S. minuta.
Lesser Tern.

\section{General Description.}

Common Tern.-Adult in summer. Bill, coral red, point black; irides, dark brown; forehead, crown, and nape, black ; back and wings, ish grey ; chin, neck, breast, and under surface, dull white; legs, coral red. Whole length, $14 \frac{1}{4}$ inches. (Tarrell.) The wings are long and pointed; tail, deeply forked. The adult female does not differ in plumage from the male.

Lesser Tern.-Adult in summer. Beak, orange, tipped with black; irides, dusky; forehead, white; crown of head and nape, jet black; back and wings, uniform delicate pearl grey; tail, forked; chin, throat, sides of neck, breast, and all the under surface of the body, pure white; legs, orange. Total length, rather more than 8 inches. (Yarrell.)

Illustration, by kind permission of Messrs. Gurney \& Jackson, from "Manual of British Birds," by Mr. Howard Saunders. 


\section{When, where, and in what numbers found.}

Both species visit us for the purpose of nesting, arriving in May and departing in September or early in October.

\section{Food.}

Their food consists of tish frr, shrimps, and crustaceans, which they take on the wing.

\section{Characteristios.}

The Terns constitute a sub-family of the numerous family Lariac, or Gulls. They are exceedingly graceful birds on the wing, their buoyant, gliding flight and deeply-forked tails having obtained for them the name of Sea Swallows.

\section{Protection.}

Wild Birds Protection Act, 1880.-These birds appear in the Schedule, which applies to every county in England, Scotland, and Ireland. Any owner, occupier, or other person taking, killing, etc., a Tern during close season,* or possessing or selling a Tern after 15 th March, is liable to a penalty of $£ 1$ for each bird.

Wild Birds Protection Act, 1894.-Eggs protected in the following Counties :Common Tern.-England : Northumberland (Farne Island); Chester ; Dorset (specified area). Scotland : Berwick ; Dumbarton ; Fife; Haddington ; Lanark ; and stirling.

Lesser Tern.-England: Dorset (specified area). IVALES: Glamorgan. Scotland : Fife; Stirling.

In Northumberland (Farne Island) and Fife the eggs of the Sandwich, Roseate, and Arctic 'l'erns are also protected.

The eggs of all species are protected in the following counties :-

England : Cumberland; Norfolk; and the Borough of Barrow-in-Furness. Scotrand : Argyll (Isles of Islay, Colonsay, Coll, and 'T'iree); Orkney.

And also in the breeding areas in the following counties :-

England: Northumberland (Holy Island); York (East Riding); Cambridge ; Chester; Norfolk; East Suffolk; Devon; Essex; Isle of Wight. Scotrand: Fife (Tentsmuir).

Any owner, occupier, or other person taking or destroying the eggs of Terns in abovenamed places is liable to a penalty of $£ 1$ for each egg.

Wild Birds Protection Act, 1896.-In addition to any penalty under the Act of 1880 the Court may now order any trap, net, smare, etc., used by the offender to be forfeited.

\section{Remarks.}

The members of the family to which the Terns belong are remarkable for the beauty and compactness of their plumage, the charming contrasts between sharply-defined black, white, and delicate pearl greys, the snowy whiteness of the under parts, in some species suffused with a blush of lovely rosy hue.

It is a lovely morning in early May, the tide is rapidly flowing over the shallow sandy beach, the ripples, dancing in the sunlight, lave the thirsty shore, and the sand eels and shrimps, liberated from tbeir hiding places, once more delight in the returning flood; off the shore small shoals of baby fish swim along close to the surface, sometimes springing into the

* Generally from 1st March to 31st July; but in some counties from 1st February to 31st August in each year. I further period may be obtained through the Act of 1896. 
air like flakes of polished silver; large Gulls are passing filr out at seid, and the Ring Dotterels are running along, busily searching for their brealifast at the margin of the warelets. A short distance out over the shallow sea a newly-arrived flock of Common Turns is leisurely beating along, fishing as they approach us. The whole flock is in constant motion, and it is difficult to leep one particular bird long under observation, but they pass in rapid succession across the field of our glasses. Never rising to any great height above the water, they are intent on watching the small fish and shrimps near the surface, and it is charming to see how they arrest themselves in full flight, the tail drawn down and wings aloft, hovering like a Kestrel, the beak pointing direct downwards, and the eve lieenly on the watch. In an instant the little fisherman has precipitated himself headlong into the sea with a force which splashes up the water all around, and he rises again, probably with a tiny fish or sand eel in his bill, or, should he have failed in his attempt, once more to pursue his deviating course. These tactics are repeated again and again by each individual of the party, the whole crossing and re-crossing, wheeling and plunging, in incessant motion, and screaming with apparent delight, until the happy little party have passed out of sight. Often they will all forsialie their fisbing to examine some strange object floating in the sea-for curiosity is one of their strong features - or to visit the boats of the fishermen, flying around in the most fearless mamner, and scrambling for fish refuse that may be thrown to them.

Towards the end of May they resort to their breediug stations, and there on the shingle, or in sheltered depressions amongst the sandhills, deposit their three rather large eggsnest there is little or none-which are of a jellowish stone colour, blotched and spotted with grey and reddish brown. When breeding the birds are alwass on the alert, rising in the air long before their treasures are reached, and, when the dinger becomes more imminent, dashing in the most fearless mamner at the intruder, at the same time filling the air with their piercing cries. In due time their pretty mottled young are hatched, their protective colouring, like that of the egrss, rendering them, when crouching in the shingle, almost invisible except to their parents, who continue to feed them until they are strong on the wing.

But all this happiness comes to an end on the 1 st of August; then the poor birds bave spread along the coast, entered the estuaries of the rivers, and haunt the piers at our watering places, where, instead of affording delight to the seaside visitors, the close time being at an end, they only form an easy prey to tre prowling gumner. So confiling are they that they can be approached without difficulty, and a wounded Tern by its screaming attracts every other Tern within hearing, so that the noble sportsman has no difficulty in making such a bag as will fully establish his reputation as a skilful fowler. Added to this, there is the professional gunner with his large orders for wings, and between these and the egger's no wonder that fewer birds each year return to their much-disturbed nesting places.

By the first week in October the Terns have almost all left our coast and gone southward.

The Lesser Tern.-In Norfolk, to which county the writer's experience of the Terns has been chiefly confined, this species is generally knowu as the "little mow," to distinguish it from the previous species, here called the "bic mow" ; other wames are the "chit pere," "shrimp-catcher," and "dip-ears," the latter highly suggestive of its mode of fishing.

Their babits are very similar to those of the larger species, and their flight equally varied and graceful. They also possess that fatal gift of curiosity which renclers them so easy of approach. A slight depression in the saud or shingle is the only receptacle for the three eggs - more often only two-and the usual locality selected is a marshy spot hetween the sandhilis on the coast; both the eggs and the young in the down are admiribly protected by their remarkable similarity in colour to the simrounding objects.

Mr. Stevenson, in his "Birds of Norfolk," gives a charming account of this bird, from which I trust I may be pardoned for making the following extract:-

"Long may it be ere these exquisite little birds cease to frequent our consts during the summer months; and yet, when considering their extended range in former dars, and the contracted area within which they are still found breceling, one can hut contemplate the 
worst result from the combined effects of shooting and egging. Too often, I am sorry to say, these delicate little creatures are slaughtered for the mere sake of sport, their pretty forms being left to rot upon the beach, to which each action of their harmless lives lent a further charm. The collector, even though with some excuse in the desire to obtain specimens for preservation and study, will feel but small delight in the possession of his prize, if, as once happened to myself at Salthouse, his victim's mate, with plaintive cries, comes hovering round. Heedless of danger to itself, this widowed bird called on its dead companion with every accent of listress and grief, and finding still no answering note, it gently seized its partner by the beak, and tried to bear it off. What would I not have given to recall that luckless shot? And oft as I remember that touching instance of animal affection, the thought occurs-

\section{" Have they no feeling? Or does man pretend \\ That he, alone, can make or mourn a friend?"}

It is these delicate and beautiful birds which are most in request-of course in their breeding plumage-to supply the "smashed birds" and groups of wings which, notwithstanding twenty years' exposure of the cruelty of the practice, still, I regret to see, are more than ever in fashion as trimmings for ladies' hats. It is quite time to speal out, and fix the blame where it is most assuredly due. After all that has been said and written, it is impossible for women to plead ignorance, and the only legitimate conclusion to which we can arrive is that they deliberately sacrifice all their finer feelings at the shrine of fashion, and care not what amount of suffering and wrong is inflicted provided their vanity is gratified. It is impossible for a lover of these beautiful gifts of God even to enter "His house without his susceptibilities being shocked by the display of these unholy trophies all around, and he wonders at the temerity of the wearers in presenting themselves even before their Maker branded with the evidence of the wanton destruction of these creatures, which $\mathrm{He}$ assures us share His care equally with ourselves, and this simply with a view to the indulgence in that passion for personal adornment which their Master condemms in such unmistakable terms. Has it never oceurred to the "modern woman" what a debasing reversion to the lower level of the savage this fondness for the display of "trophies" indicates? It is argued that these wings and plumes are so beatiful, and this is true of everything in its right place. How beautiful the wing of a bird is only they can know who have studied the wonderful arrangement and ultimate structure of each feather; and surely such an one would not apply it to so base a purpose. So also is the human head beautiful; but to the writer, and I doubt not to many others, the sheaf of wings, or the distorted body of a bird, displayed in a woman's hat is as repulsive an object as the dried human head which adorns a Dyak dwelling, or the scalp hanging from the wampum belt of the North American Indian. All alike are emblems of barbarism, however much in the one case they may be glossed over by the veneer of "civilization."

Educational Series.-No. 1.-OWLS. No. 2.-WOODPECKERS. No. 3.-STARLING. No. 4.-SWALLOWS. No. 5.-KINGFISHER. No. 6.-OSPREY. No. 7.-DIPPERS. No. 8.-NIGHTJAR. No. 9. -TITMICE. No. 10.-KESTREL. No. 11.-PLOVERS. No.12,-TERNS. No. 13.-WAGTAILS. No. 14.-CHOUGH. No. 15.-JAY. No. 16. -SKUAS.

Others in course of preparation.

Copies of the above may be obtained from the Society's Publishing Department, Knowledge Office, 326, High Holborn, W.C., or from the Hon. Sec., Mrs. F. E. Lexon, Hillerest, Redhill, on the following terms:-Post free: three copies of any one number of the Series, 1d.; one dozen, 3d.; 100, 18. 6d. Assorted packets, one copy of any six numbers, 2d, ; one copy of any twelve, or two copies of any six numbers, 4d.; or 50 assorted numbers, 1s. Special terms for larger quantities to County Councils, the Constabulary, and Schools. 


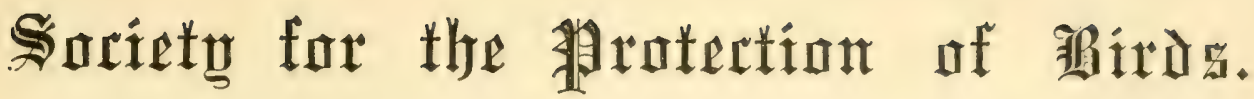

EDUCATIONAL SERIES. Edited by H. E. DRESSER, F.L.S., F.Z.S.

No. I3.-WAGTAILS.

BY W. WARDE FOWLER.

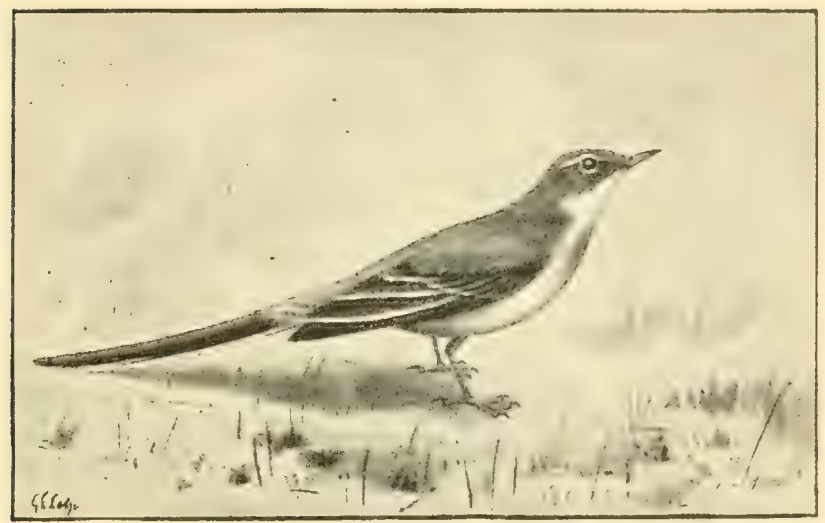

GREY WAGTAIL.

\section{Names.-PIED WAGTAIL, GREY WAGTAIL, YELLOW (or Ray's) WAGTAIL.}

Family-Motacillidie.

Genus-Motacilla.

Species-M. Iugubris. Pied Wagtail. M. melanope. Grey Wagtail.

\section{General Description.}

M. raii. Yellow Wagtail.

1. Pied Wagtail.-Adult male in breeding plumage: forehead and sides of the head and neck pure white, contrasting strongly with the deep black of crown, nape, throat, and breast; upper parts and wing-coverts black, and the latter margined with white, forming a double bar; wing-quills blackish; tail black, except the outer two pairs, which are mainly white; belly white; bill, legs, and feet, black. Length 7 i. inches, wing $3 \frac{1}{2}$ inches. The female has the back chiefly grey, and has less black on head and breast. In winter both sexes lose the blick chin and throat, and become grerer on the back. 'The young are grey of various shades, and are often called Grey Wagtails by the inexperienced.

2. Grex Wagtail.-Adult male in breeding plumage: crown, ear-coverts, and upper: parts generally, slate-grey; a narrow white streak above the eye, and a broad white line below it, running to the neck; wing feathers brownish-black, the long secondaries with whitish margins; tail feathers blackish, except the outside pair, which are white, and the next two pairs, which are partly so ; chin and throat black; breast and under parts sulphur-yellow; bill, legs, and feet, brown. Length rather more 
than 7 inches, wing $3 \frac{1}{3}$ inches. The female is a little duller in colour, her tail is slightly shorter, but in both sexes it is conspicuously long. The young are duller and browner.

3. YELLOW WAGTAIL.-Adult male in breeding plumage: head and upper parts greenisholive, but the forehead is yellower, and there is a comspicuous yellow streak over the eye; wings brown; tail feathers blackish-brown, except the two outer pair, which are almost white; under parts sulphur-yellow; bill, legs, and feet, black. Length about 6 inches, wing $3 \frac{1}{10}$ inches. The female is browner above, and the yellow parts are less bright. In autumn both sexes become paler. The young are at first greenish-brown above, and buff below, but soon grow more like their parents.

\section{Where, when, and in what numbers found.}

The Pied Wagtail is a common resident throughont the lingdom, but it has a tendency to more from north to south in autumn, and inany migrate at that time to France, returning in spring.

The Grey Wagtail is resident in all parts of Great Britain where there are swift streams, and is not uncommon in Ireland. In winter many descend to the lower country, but few remain there to breed, and only when they are tempted by some mill stream or artificial water-fall.

The Yellow Wagtail is a summer visitor only, fairly abundant in all pasture lands in England, but less common in the north and in Ireland. It arrives in April and leaves us in september.

\section{Food.}

All the Wagtails are insect eaters, as anyone may see for himself on lawn or meadow, or by the brookside. This is the reason why the Pied and Yellow species are so fond of running: about by cattle and sheep, which stir up the insects as they graze. The Grey Wagtail also eats small molluses, which it finds in the brooks, and is fond of minute beetles; but this bird will frequent a lawn if it be near the nest, and pick up insects in the same charming frisky manner as the Pied Wagtail.

\section{Y. Characteristics.}

The Wagtails, like their near relations the Pipits, are birds of very well marked habits, in which they all closely resemble each other. They all rum instead of hopping, they all have a very graceful undulating flight, and the shrill short call note is in all the three species much alike, though that of the Yellow Wagtail, the smallest of the three, is finer and higher in pitch. But the leading characteristic of the genus is the tail motion, which has earned for these birds many local names, such as Dishwasher. The longest tail of the three is that of the Grey Wagtail, which is seldom still; it is moved up and down together with the whole body, while in the other species it is "wasged" more independently of the body, and less persistently. In nesting habits the three species differ to some extent. The Pied Wagtail's nest may be almost anywhere-in banks, walls, cattle sheds, thatch, or in any place likely to escaje the notice of its persistent enemy the Cuckoo. It is particularly fond of railway stations, where it almost always meets with protection from the officials. The eggs are greyish-white in ground colour, spotted all over with greyish-brown. The Grey Wagtail will sometimes build in walls covered with creepers, or in the rafters of a boathouse; but its usual choice is a steep bank near water, and it prefers to have a ledge of rock overhanging the nest. The eggs of this bird are as a rule pale grey, mottled with light brown. The Yellow Wagtail builds always on the ground, often in a cornfield and in a furrow, and its eggs closely resemble those of the Grey Wagtail. All three species use much the same material for the nest; it is generally of dried grass, roots, and moss and hair, but differs both in material and bulk according to the position and locality. 


\section{Protection.}

Wild Birds Protection Act, 1880.-These birds do not appear in the Schedule, but have been added in the following counties:-

Pied Wagtail.-England : Laneaster, Bucks, Chester (Hundred of Wirrall), Leicester, Rutland, Stafford, West Suffolk, Worcester, Isle of Wight. Wales: Brecon.

Grey Wagtail._England: Lancaster, Bucks, Leicester, Rutland, Stafford, West Suffoll. WaLES: Breeon.

Yellow Wagtail.-EnGLAND: Taneaster, Bucks, Chester (Hundred of Wirrall), Leicester, Rutland, Stafford, West Suffolk, Worcester, Isle of Wight. WALES : Brecon. Scotrand : Berwick.

White Wagtail. - ENGLAND : Leicester, Rutland, Stafford, West Suffolk.

In these Counties any owner or occupier, or other person, taking, killing, etc., any of these birds during close season,* or possessing or selling one of them after 15th March, is liable to a penalty of $£ 1$ for each bird. In any other place anyone other than the owner or occupier of land, or his agent, taking, killing, etc., any Wagtail during close season, or possessing or selling a Wagtail after 15th March, is liable to a penalty of $5 \mathrm{~s}$. for each bird.

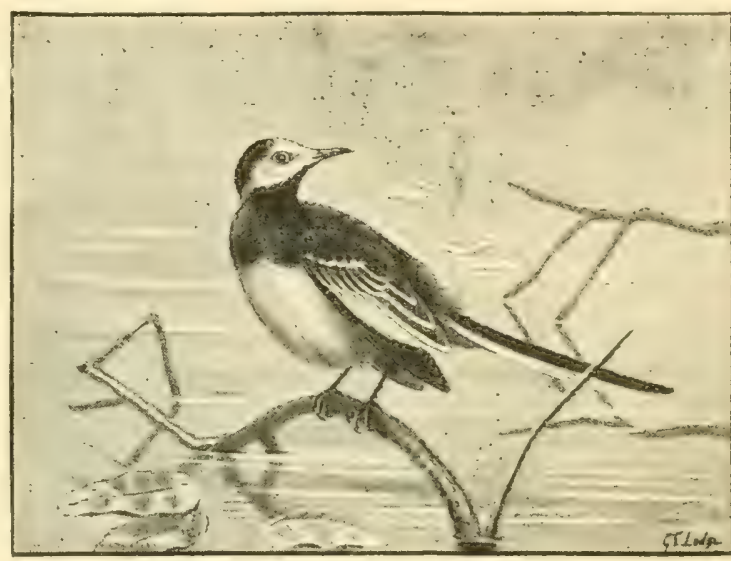

PIED WAGTAIL. counties :-

Wild Birds Protection Act, 1894.-The eggs are protected (1897) in the following

All Species.-England : Durham, Leicester, West Suffolk, Metropolitan Police District (including London and Middlesex). Wates: Pembroke. Scotland: Orkney.

Pied Wagtail.-WALES: Brecon.

Yellow Wagtail.-Wales: Brecon. Scotland: Berwick.

White Wagtail.-England : Devonshire.

In the above places any owner or occupier, or other person, taking or destroying the eggs of these birds is liable to a penalty of $£ 1$ for each egg.

Wild Birds Protection Act, 1896. - In addition to any penalty under the Act of 1880, the Court may now order any trap, net, snare, etc., used by the offerider, to be forfeited.

All Wagtails are protected throughout the whole year in the counties of London, Middlesex, Essex (M.P. District and Parishes of Epping, Theydon Bois, ete.), and the Boroughs of Cardiff and Kingston-upon-Hull.

\section{Remarks.}

The true way to induce in young people a kindly feeling towards animals is surely to teach them to notice their habits, and to learn something about them. Among birds the Wagtails, like the Swallow tribe, form a convenient group for this purpose. They are comparatively tame and trustful; they are conspicuous, especially in the breeding season; they are most beautiful in shape and in gesture. Their common characteristies are strongly

* Generally from 1st March to 31st July-but in some counties from 1st February to 31st Augus iu each year. A further period may be obtained through the Act of 1896 . 
marked, yet they differ among themselves both in habit and colouring, and their varieties of plumage at different seasons of the year form a most interesting study for a beginner. It may be remarked that there are two other species for which a look out may always be kept in this country, a fact which gives a special interest to almost every Wagtail that presents itself to the eye. These are the White Wagtail (M. alba), which closely resembles the Pied Wagtail, but has a grey back instead of a black one in the summer, and the Blue-headed Wagtail (M. flava), which is hardly to be distinguished from the Yellow Wagtail, except by its bluish-grey head and a white stripe over the eye. These two may always be found on the Continent, together (in some localities) with other forms slightly differing from each other, the many varieties thus combining to make the whole group a most interesting and profitable object of study. But the learner at home will find plenty to do in observing the three species described above, their movements and changes of plumage at different times of the year, as well as their nesting habits, and their relation to the Pipits; and there are, fortunately, few parts of England and Wales where all three may not be seen at one time or another.

As an instance of the utility of these birds I may cite the following from the "Gardeners' Magazine," viz. :-“"The

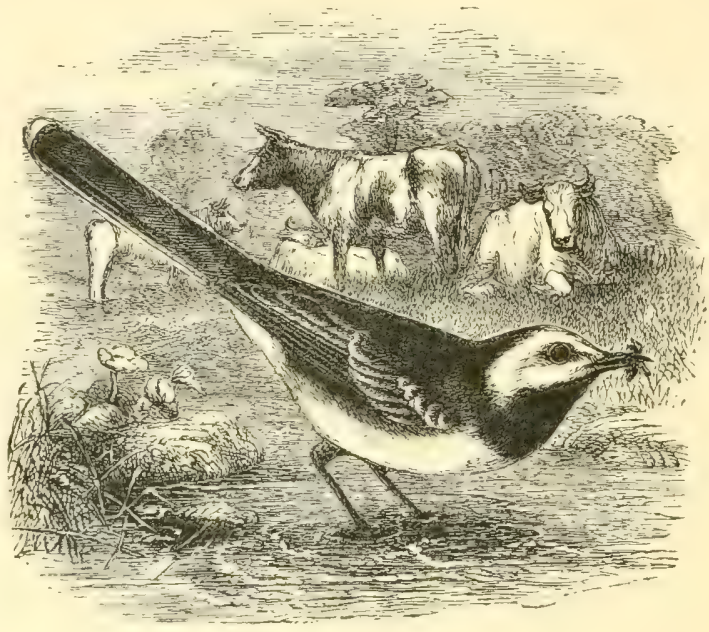

PIED WAGTAIL, Wagtails afford a peculiar example of the indirect usefulness of small birds. The liver-fluke, that so often devastates our flocks and herds, begins its career in the body of a water-snail. In browsing on marshy pastures, the cattle and sheep take with their herbage a considerable number of snails, and, consequently, a considerable number of embryonic entozoa, or, say, incipient flukes. Amongst thousands of flukes swallowerl and digested, a few will escape and find their way to the livers and brains of the animals, and there begin their work of destruction. The Wagtail affords a great protection, as he is persistently fond of marsh snails, and the marsh farmer is his own enemy if he destroys the birds."

Educational Series.-No. 1.-OWLS. No. 2.-WOODPECKERS. No. 3.-STARLING. No. 4.SWALLOWS. No. 5.-KINGFISHER. No. 6.-OSPREY. No. 7.-DIPPERS. No. 8. -NIGHTJAR. No. 9. -TITMICE. No. 10.-KESTREL. No. 11.-PLOYERS. No.12,-TERNS. No. 13.-WAGTAILS. No. 14.-CHOUGH. No. 15.-JAY. No. 16.-SKUAS.

Others in course of preparation.

Copies of the abore may be obtained from the Society's Publishing Department, Knowledge Oflice, 326, High Holborn, W.C., or from the Hon. Sec, Mrs. F. E. Lesron, Hillerest, Redhill, on the following terms:-Post free: three copies of any one number of the Series, 1d, ; one dozen, 3d.; 100, 1s. 6d. Assorted packets, one copy of any six numbers, 2d.; one copy of any twelve, or two copies of any six numbers, 4d; or 50 assorted numbers, 1s. Special terms for larger quantities, and ts County Councils, the Constabulary, and Schools.

Illustration by Joseph Wolf, from "British Birds in their Haunts," by kind permission of the Society for Promoting Christian Knowledge,

The Society's Publishing Office, Knowledge, 326, High Holborn, London, W.C. 1897. 


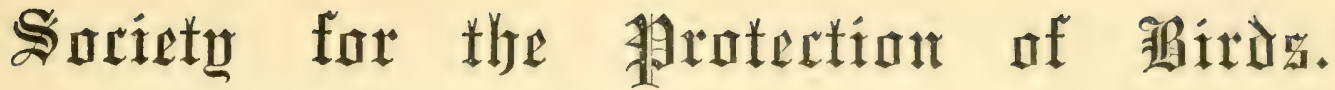

EDUCATIONAL SERIES. Edited by H. E. DRESSER, F.L.S., F.Z.S.

\section{No. 14.-CHOUGH.}

By J. A. HARVIE-BROIVN, F.R.S.L., F.Z.S., ETC.

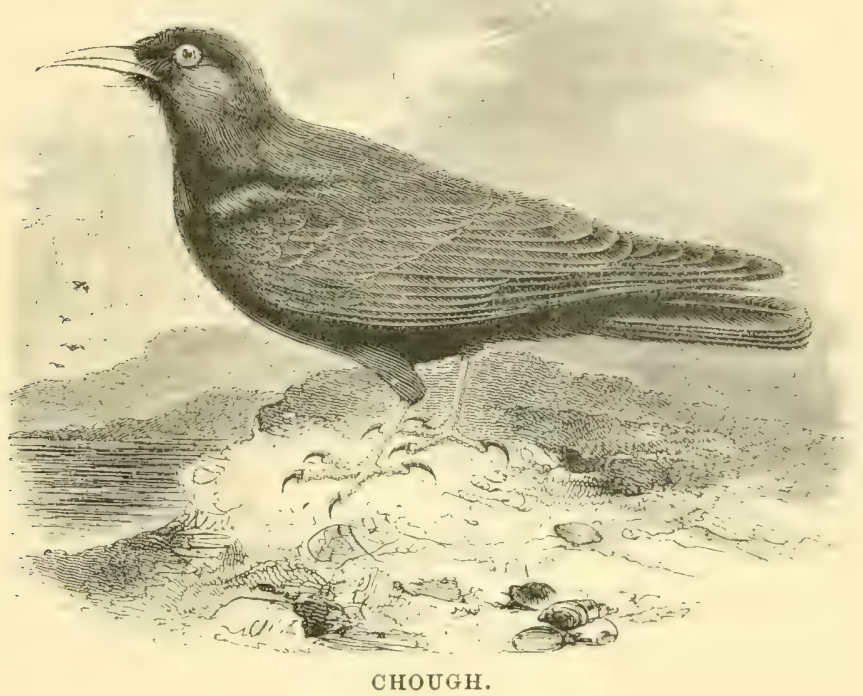

\section{Name-CHOUGH.}

Family.-Corvidx.

Genus.-Pyrrhocorax. P. graculus $(L)$.

\section{General Description.}

Entire plumage jet black, glossed on the body with steely blue, and on the wings and tail with greenish blue; iris, brown; beak and legs, coral or vermilion red; claws, horny black. Total length about $16 \frac{1}{2} \mathrm{in}$; ; wing, $10 \frac{3}{4} \mathrm{in}$; ; tail, $5 \frac{1}{2}$ in.

\section{Where, when, and in what numbers found.}

The Chough is found throughout the Palwaretic region, as fir morth in Europe as the British Isles, but is of somewhat local distribution. In Britain it is less frequent than formerly, and the causes of the reduction in its numbers are difficult to explain. It is not rare in the Channel Islands, still survives along the south coast of Englind, but in limited

Illustration, by kind permission of Messrs. Cturney \& Jackson, from "Manual of British Birds," by Mr. Howard Saunders. 
numbers and locally as far as Cornwall; mot rare in the north of Devon, but has become scarce on Lundy Island; found on the sea cliffs of Wales, and at some inland localities there. As a nesting species in Wigtownshire and Ayrshire it has almost, if not quite, ranished, but occasionally a few are seen at their old haunts. Thence, northwards in Scotland, it is found in Gigha, Islay, and Jura, and in the west and east of Skye, and in a very few other localities which we do not name; but Skye contains its most northerly distribution as a nesting species.

The Chough is also known to revisit old long-deserted haunts in the south-east of Scotland, as well as in the south-west. The late $\mathbf{M r}$. Robert Gray appears to have given some credit to early reports of its presence at 'Troup Head, in North Aberdeenshire, and has since been quoted for this locality by Dresser. Gray said, howerer, in partial caution : "Indeed, it may be questioned if a single Chough has been seen either at Troup Head or at St. Abb's Head for the last ten or fifteen years." A. G. More at that time carried the distribution as far north as Sutherland; but Mr. George Sim, commenting upon these records, says, with regard to the North Aberdeenshire coast, "Gray might have more truly said thirty or forty years ago," and we are of the same opinion.

In Ireland it is still abundant, though restricted for the most part to the precipices of the sea cliffs of the north and west of the country.

\section{Food.}

Principally insects, crubs, larvæ, beetles, and more rarels grain; perhaps occasionally carrion, as often quoted by authors, but the original source of which information we have not been able to discover. Personally we think it more likely beetles and grubs in the said carrion that are the objects of their attention.

\section{Characteristics.}

Whilst shy or restless at their nesting haunts, Choughs are more confiding at other seasons, or when feeding or at plar. They are sprightly birds both on land and when on wing, gambolling as they fly in companies along the irregularly contoured sea cliffs, or at inland haunts, imitating the manner of other species of the genus, especially of the Raven; and play and frisk and turn somersaults in infinitely amusing fashion at times and seasons when on land.

The nest is not usually a bulky structure-or, at least, not often so bulky as a Jackdaw'sthough occasionally it assumes considerable dimensions; more often, however, very little material at all is used.

The eggs vary less in coloration than others of the genus. In colour they range from pale greenish grey ground colour to creamier and whiter tints, marked more or less profusely with black, purple, or lilac (underlying the shell) blotches, and less frequently streaks. Size about $1 \frac{1}{2}$ in. by $1 \frac{1}{12}$ in.

\section{Protection.}

Wild Birds Protection Act, 1880. - This bird appears in the Schedule which applies to every county in England, Scotland, and Ireland. Any owner, occupier, or other person, taking, killing, etc., a Chough during close season, * or possessing or selling a Chough after 15th March, is liable to a penalty of $£ 1$ for each bird.

* Generally from 1st Mareh to 31st July; but in some counties from 1st February to 31st August in each year. A further period may be obtained through the Act of 1896 . 


\section{Counties :- \\ Wild Birds Protection Act, 1894.--The eggs are protected in the following}

England : Cornwall ; Devonshire; Dorset (apecified area).

Scotcand: Argyll; Dumbarton; Elgin; Kirkeudbright; Vigtown.

Any omner, occupier, or other person taking or destroying the eggs of the Chnugh in abore-named places is liable to a penalty of $\& 1$ for each egg.

Wild Birds Protection Act, 1896. - In addition to any penalty under the Act, 1880. the Court may now urder any trap, net, sware, etc., used hy the offender to be forfeited.

\section{Remarks.}

We have had personal experiences of the species in its native laumts in Cornwall in 1863, several of the Inner Hebrides, and Coast of Sliye; but we did not see them in the Channel Islands.

Although the Chough has become much scarcer than formerly, it is still kmown-as w" have already indicated-to return occasionally to some of its old haunts. It mily be desirable: in this place to mention some of these deserted nesting stations, with the view of induring more efficient protection in the future, and calling in for that purpose the latest "resources of civilization." With encouragement aud careful attention at such places as I will name, there seems little doubt they might reasonably be expected to return permanently, and not only to visit them but to reoceupy them. Thus I would specially enumerate the old coast and inland localities in Ayrshire and WVigtownshire and the south-west generally of Scotlind, the Berwickshire coast, Inner Hebrides (where proprictors can keep watch and ward), and the coasts of Campbelltown and the Mull of Kintyre; and also, of course, all presently occupierl situations. In this connection, all the particulars so interestingly conveged by the late Mr. Robert Gray in his "Birds of the WVest of Scotland," should have the most careful attention bestowed upon them by active members and petitioners of the several Count councils. We know where the few remaining sites are rigidly preserved, and also where thes are neglected. It is here that the Count Councils can do a great deal of good. Proprietors in some places can and do effectually jreserve their Choughs and other rare hirls, but the assistance of the law has over and over again proved of great value; to witness which statement we have only of our knowledge to instance the case of the Great Sliva in Foula and Shetland.

The Chough ought to receive attention from the County Councils of the following counties in Scotland, viz.:-Berwickshire, East Haddington, Stirlingshire, Wigtownshire, Kirkcudbright, Renfrew, Ayr, Dumbarton, Argyll, the Inner Hebrides, Skye-wherever these County Councils have not already provided for its safety.

Several reasons for the decrease of their numbers have from time to time been put forward, but, as we have already said, it is extremely difficult to decide which factor or factors have been most instrumental in causing their disappearance.

The increase of the Jackdaw cousinship is certainly a marked feature in ornitlological history, and this, by many people, and by some writers, has been assigned as a primiry ("anst" at certain localities. But this camnot be applied in connection with the early desertion of the Outer Hebrides, where, as we are informed by Macgillivray, it was present in Barra prior to 1830, because then, and now at the present day, the Jackdaw was and is a rare bird in these Outer Islands. The known increase of Jackdaws among the Inner Isles, howerer-it is possible-may present opportunities for observers to compare statistics. In the cathertral of 
Tona, a pair or two used to live amongst the crowd of cousins-some thirty pairs of Jackdarss. Grabam considered that " the Choughs were always friendly," but perhaps they were obliged to be, and the cousins only reciprocated until more pressing times arrived. Certainly we would never advocate the protection, or at least orer-protection, of Jackdaws. We have little trust in their good faith. Their pilfering habits, Tammany-Ring proclivities, and general upperhand assertiveness of character, and of numbers, make them at least "suspicious cbaracters" towards their weaker-billed relations. They treat other weaker species badly, and even pilfer from "royal" sanctuaries. It is their nature.

The direct influence of man does not appear to have had much to do with the decrease of the Chough, certainly - at least at our Scottish localities-but it rests with us to make sure, so far as we can, that it be not our fault if they do not again increase.

The Peregrine Falcon is quite an abundant species in Scotland, well able to maintain its own. It has been-and we admit not without reason-accused of being instrumental in the decrease of the Chough; and indeed it has, not once, but several times, been stated to us that the Chough is a bird it is particularly fond of. We strongly incline to the belief that the Peregrine has caused the disappearance of the Chough from more than one west island locality, and of these mostly such islands as are limited in extent of coast-line; and where Peregrine Falcons have long been known to hold their watch-towers, we can easily enumerate several of these, but here will only mention the Island of Eigg ( $v$. "The Vertebrate Fauna of Argyll and the Inner Hebrides," pp. lix. and 86) : and the belief also regarding the formerly well-stocked islauds of Gigha and Cara, not to speak also of the opposite shores of Kintyre.

We may seem to our readers to have dwelt at great leugth on these coincidences, but we act upon the principle that:-as a Society for the Protection of Birds we ought not to shirk the "why and the wherefore," lest by rash application of the law, injustice to any species may be wrought, as has over and orer been done before by acclinatization societies-for instance, the rabbit in Australia and New Zealind, and following it the stoat and weasel! - and the injustice done by over-preservation and ill-considered "acclimatization" of species utterly inimical to the natural state of things.

The Chough cannot be considered a migratory bird. It is indeed a local species, and also a locally resident species. Therefore do not let nan shoot, trap, or destroy them. If they for selfish ends and purposes do so, then their true friends-naturalists-cannot hope to see any improvement in their status and future welfare.

Thus, then, we close our case for our plaintiff, who asks the pathetic question"Can you show any Caws why I should not be protected?"

Educational Series.-No. 1.-OWLS. No. 2.-WOODPECKERS. No. 3.-STARLING. No. 4.SWALLOWS. No. 5.-KINGFISHER. No. 6.-OSPREY. No. 7.-DIPPERS. No. 8. -NIGHTJAR. No. 9. -TITMICE. No. 10.-KESTREL. No.11.-PLOYERS. No.12.-TERNS. No.13.-WAGTAILS. No. 14.-CHOUGH. No. 15.-JAY. No, 16.-SKUAS.

Others in course of preparation.

Copies of the abore may be obtained from the Society's Publishing Department, Knowledge Office, 326, High Holborn, W.C., or from the Hon. Sec., Mrs. F. E. Lexon, Hillcrest, Redhill, on the following terms:- Post free: three copies of any one number of the Series, 1 d.: one dozen, $3 \mathrm{~d} . ; 100,1 \mathrm{~s} .6 \mathrm{~d}$. Assorted packets, one copy of any six numbers, 2d.; one copy of any twelve, or two copies of any six numbers $4 \mathrm{~d}$. ; or 50 assorted numbers, $1 \mathrm{~s}$, Special terms for larger quantities to County Councils, the Constabulary and Schools.

The Society's Publishing Office, Knowledge, 326, High Holborn, London, W.C. 1897. 


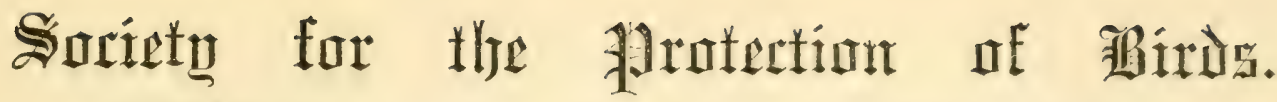 \\ EDUCATIONAL SERIES. Edited by H. E. DRESSER, F.L.S., F.Z.S.}

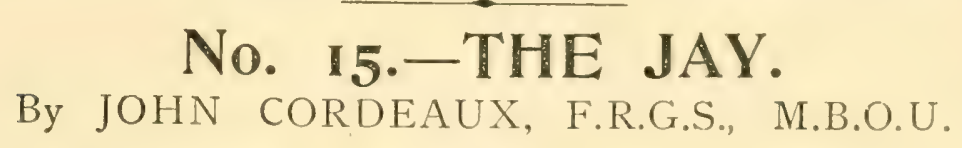

\section{Name-JAY.}

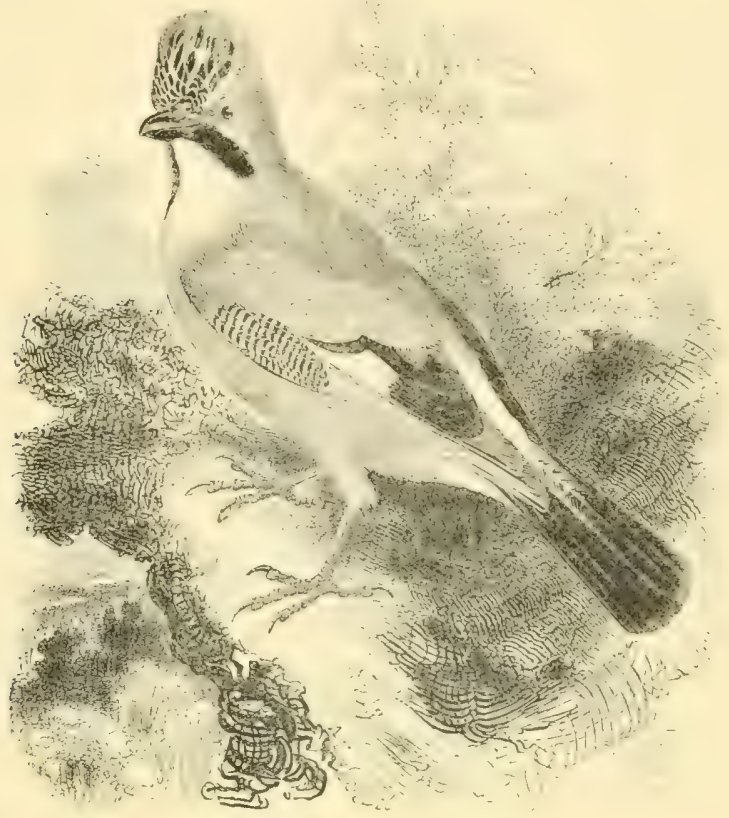

Family-Corvide.

Sub-Family-Garruline. Garrulus glandarius (Linn).

\section{General Description.}

JAY.-Adult male: crest whitish, the feathers either tipped or striped down the centre with black; chin and throat white bordered with a broad black streak running dowuward cu each side from the base of the bill; upper parts, vinaceous browll; primaries black, margined with dull white; secondary quills black, whth haif the outer webs white; innermost feathers chestuut, and tipped with blick; under parts. jale cinnamon. The most consuicuous and attractive portion of the plumage is the turyuoise and cobalt patch on the wines, harred transversely with black; rump and under tail-coverts white; tail blizek, with indistinct bluish hars at base. Length, $14 \frac{1}{2}$ inches; extent of wing, 23 inches. Irides, pale blue; legs and feet, pale brown. The female has the erest less proulued, colour less hright, and the hlu. of th.. wing less pure. Young birds of the year are without the blue irides.

III. Where, when, and in what numbers found.

The Jay is a resident throughout the year in the British Islinds, also over the reater. part of the Continent, from the Aretic Circle to the II diterimean Islinds, and frum the

Illustration, by kind permission of Messrs. Gurney \& Jackscn, from "Manual of British Birds," by Mr. Howard Saunders. 
Ural to the Atlantic. In many localities in England and Scotland it is a decreasing species. In the eastern counties, and also the south-eastern, the rinks of the resident jays are swollen in the autumn by occasion ll flights, presumably eoming from the Continent. These spread over the country, or pass through from north-east to south-west.

\section{Food.}

The Jay is practicelly omnivorous, and it is credited with eating a great variety of substances. Principally its food is insects and their larve, beetles, worms, slugs, snails, fruit and wild berries, beech-mist, acorns, oak-galls, graiu of all sorts, mice and shrews. egrgs, and young birds.

\section{Characteristics.}

The Jay is cautious, shy, and retirug in its habits, frequenting woodlands, plintations, copses. thick hedgerows full of timber trees, and fox covers. It will announce its presence in those solitades by harsh unmusical screams, but in the nesting season the wary bird remains mute for the purposes of concealment, retiring before an intruder in short flights from tree to tre", or dropping beneath the top of the underwood and hiding in the deusest part of the covert. In the shooting season, when much disturbed by heaters and repeated tiriug, jays will leave a wood, retreating, when practicable, aloug some well-timbered hedgerow, from tree to tree. Their undulating flight on these occissions is laborious, uncertain, and weak, with slow heats of the wings. It is able, however, on migration to cross the North Sea, and with apparent ease, in large flights. Jass feer much on the ground heneith trees and underwood, and du not, as a rule, care to go far from covert, or into large open spates and fields, such as ar. resorted to by rooks and jacklaws. It will, however, visit plots of peas in the open field, the. temptation overpowering its usually discreet movements. On the ground the Jay does not walk, but advances by a series of hops.

The nest is a compact structure of sticks and twigs, lined with fine roots and dead grasses, often placed in the fork of a timber tree, or a fir, holly, yew, or hiawthorn. A favourite spot is against the ivy-covered bole of a tree, or concealed hehind a mass of climbing honeysuckle. The egrs-five to seven-are greenish-grey, densely spotted with olive-brown, more particularly at the large eud, where they sometimes form a zone.

\section{Protection.}

Wild Birds Protection Act, 1880.-This bird does not appear in the Schedule to thr

Act, but has been added in the following counties:--

ScoThand: Banff; Haddington; Midlothian.

In these Counties any owner or occupier, or other person, taking, lilling, etc., any Iay during close season, ${ }^{*}$ or possessing or selling one of them atter 15 th March, is liable to it penaliy of \&l for each bird. In all other places anyone, other than the owner or occupier of Land, or his agent, taking, lilling, etc., a Jay during close season, or possessing or selling a Jay after 15 th of March, is liable to a penalty of $5 \mathrm{~s}$. for each bird.

Wild Birds Protection Act, 1894.-The eggs of the Taly are protected in the following Counties :-

Scotrand : Banff; Haddington; Midlothian.

And in the breeding areas established in the following Counties:-

England: Northumberland (Holy Island); York-East Riding; Cambridge;

Cheshire; Norfolk; East Suffolk; Devon; Essex; Kent; Isle of Wight.

Scotland: Fife.

Any uwner or other person taking or destroying the eggs of a Jay iu the above-named areas is liable to a penalty of $£ 1$ for each egg.

* Generally from lst March to 31 st July; but in some counties from 1st February to 31st August in aach year. A further period may be obtained through the Act of 1896. 
Wild Birds Protection Act, 1896.--In addition to any renalty umler the Act. 1880, the Court may now order any trap, net, snare, etc., used by the offender to be forfeited. The Jay is protected throughout the whole year in the Borough of Cardiff.

\section{Remarks.}

Regarding the present status of the Jay in the British Islands, atcording to the littest information, it is not found in Shetland. Dr. Saxby only once saw a single bird off Halligarth going south on migration. We can find no record of its oecurrence in Orliner, nor in the most northern of the Scottish counties. In Southern Scotland it is yet fairly common in some counties, or portions of counties, but rapidly decreasing through the persistent persecution of lieepers.

In Ireland it is restricted (according to Mr. Allan Ellison, Zool. 88, j). 106i) to Killinmy and Queen's Counties, with parts of Carlow, Kildare, King's Count and 'Tipperary.

In many parts of England, where game preserving is carried to excess, it has become practically extinct. In some other localities, however, it is yet tolerably plentiful.

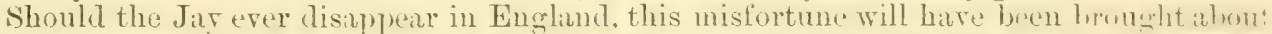
by three causes. 'The hostility and persecution of cameleepers; the demame for the wins:

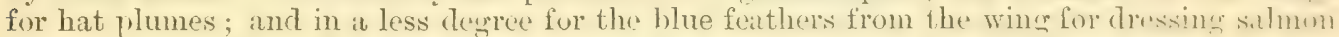
flies. The chief and most wholesale destruction is due to the first of these causes. Gamekeepers are not the most discriminating of men; there are certain dislikes and prejudices which neither time, argument, or persuasion will ever induce them, as a class, to forego. The

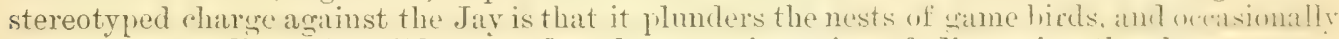
snaps up a nestling. Possibly so, and we have no intention of disproving the charges; yet, on the other side, we can testify that when resident in an old manor house, close to great woodlands where Jays aboumded, and at a time when we save speedial attention to the increase

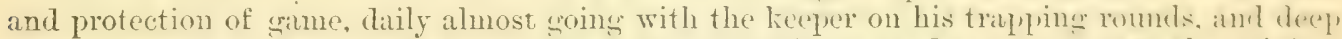
in every question relating to woorleratt, in these now far away days we camn tu thr "prinion.

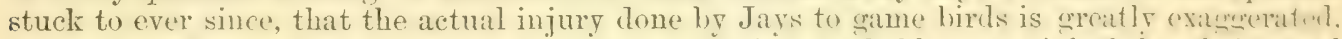
and not really worth taking into consideration, being probathly outweigher by their gaxd deeds in other directions. What we dicl not like was their partiality for riju cherries ans? filberts. 'The first, howerer, was alwats effectudly cruarderl by nets, and the serond lyy the occasional firing of a gum or pistol by the sartener. "This, in a short time, matre the thiore: most cautious in their approaches.

Jays are frequently taken in pole-traps, set in rides or open places in woods. This is ir device for slowly torturing innocent birds to death, which, for ingenuity and cold-hisertur cruelty, smuatsses everything else of its sort. Shame, sheme, we say, on auy who still continur to either use or countenance this atrocity, which has done, and is duing, more than anything else, to bring discredit on the excessive preservation of game.

There are some few landed gentry who will not allow their lieepers a free hand, and we know of two charming country homes where one of the prettiest sights is to wath the . Jia:

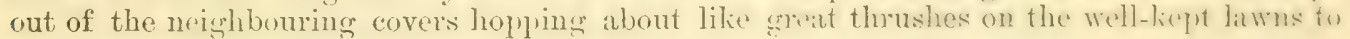
pick up grains of Indian corn scattered for them.

of the many associations which vive a charm to Enerlsh rumal life, the scoldiner ary of the Jay, coming from some sheltered copse, is not the least pleasient. (owper was wil aware of this when he wrote-

\footnotetext{
"The cawing rooks, and kites, which swim sublime

In still repeated circles, screaming loud,

The jay, the pie, and e'en the boding owl

That hails the rising moon, have charms for me."
}

Of these, the Kite has gone, and, we fear, for ever; and the Jaty, the Pin. and Owl (nnly continue to exist, in vastly reduced numbers, by the forbearance of the few.

Space would not allow us to go as fully into the subject as we would have wishert. Wp cannot, however, pass over one of the most remarliable facts in connection with the lifh. 
history of the Jay, namely, its migrations. It is a well-known fact that large numbers of these birds appear suddenly in the autumn - to the great surprise and discomfiture of the leeper, who wonders what the guv'nor will think-in woods where they are seldom seen at other seasons.

This was so in 1877 , between Octoleer 18 th and 22nd, when Jays, previously rare birds, became exceedingly plentiful in the woods of Oxfordshire. In 1879 a flight of two to three hundred came in close to Dover, and after a short rest proceeded inland. Again in 1-82, early in October, in West Lincolnshire, Northamptoushire, and Oxfordshire, large numbers of Jays were observed, as well as in parts of south-west England.

Let us see what was going on in a corner of Western Europe on that date. That veteran ornithologist, the late Herr Giatke, of Heligoland, in his diary, under date of Oetober 6th, 1882, says: "A stormy south-east wind, weather clear: Jays in hundreds ; Hedge Sparrows in umprecedented numbers ; Chaffinches and Meadow Pipits in hundreds of thousands." On the 7 th the entries are: "Wind south-east, almost a storm, weather clear: Jays travelling across the island uninterruptedly in hosts of thousands and millions; enormous numbers of Hedge Sparrows, Chaffinches, and Meadow Pipits." On the 8th: "Wind south-east, freshening, weather clear; Jays in still greater numbers than on the day before, uninterrupted swarms, counting to thousands, passing across, as well to north and south of the island." since 1882 only one solitary individual has been seen. It is scarcely probable that our English woodlands would take a tithe of those munlers; it is therefore likely that the main body went further south, into France and Spain.

There is nothing more marvellous in the whole range of our knowledge than this outgoing of the Jays, beeause they are weak-ringed birds, with body-feathers loose and fluffy, and a somewhat ummanatreable tail in a sale of wind; also they are not ranked amongst regular migrants, spending their days in emdiess flittings to and fro from tree to tree. Why are they here, then, on the confines of Western Europe in assembled thousands? Surely thi forest lands from the Elbe to the Vistula, and the Vistula to the Ural, are wide and deep enough to shelter and supply food for the whole tribe. Then why the need of this pxodus? and what impulse, or feeling of necessity, working in each individual, urges forward collectively their long flight-out and away-into the unknown? From below comes no murmur of beech boughs, no sighing of pine tops, only the eternal wash and rumble of the cold, grey, pitiless sea, and on every side a limitless water-horizon, which for anything they can know to the contrary (being probably birds of the year) may prove an Atlantic, an ocean without a further shore. Did Columbus and his sailors ever venture more?

A local name of the Jay in Lincolnshire is "Popinjay," a gaily-coloured figure of a bird set up as a mark to be sliot at, in the days of the long-buw and cross-bow. "Jay," too, was a term of contempt, as applied to some gaily dressed fellow. Thus in Cymbelline (Act III., Sc. 4) :-

$$
\text { "Some jay of Italy has betrayed him." }
$$

Educational Series.-No. 1.-0WLS. No. 2.-WOODPECKERS. No. 3.-STARLING. No. 4.SWALLOWS. No. 5.-KINGFISHER. No. 6.-OSPREY. No. 7.-DIPPERS. No. 8.-NIGHTJAR. No. 9.-TITMICE. No. 10. KESTREL. No.11.-PLOVERS. No. 12.-TERNS. No. 13.-WAGTAILS. No. 14.-CHOUGH. No. 15.-JAY. No. 16. - SKUAS.

$$
\text { Others in course of preparation. }
$$

Copies of the above may be obtained from the Society's Publishing Department, Knowledye Ofice, 326, High Holborn, W.C., or from the Hon. Sec., Mrs. F. E. Lesron, Hillcrest, Redhill, on the following terms:- Pust free : 1hree copies of any one number of the Series, 1d.; one dozen, 3d.; 100, 1s. 6d. Assorted packets, one copy of any six numbers, 2d.; one copy of any twelve, or two copies of any six numbers, $4 \mathrm{~d}$., or 50 assorted numbers, 1s. ispecial terms for larger quantities to County Councils, the Constabulary, and Schools.

'The Society's Publishing Office, Knovledge, 326, High Holworu, London, W.C. 1897. 


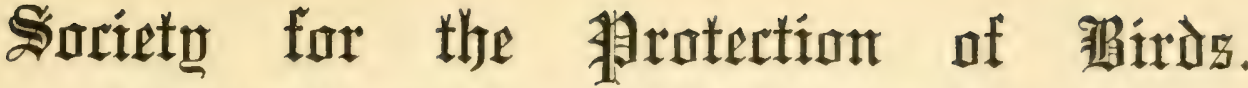

EDUCATIONAL SERIES. Edited by H. E. DRESSER, F.L.S., F.Z.S.

\section{No. I6.-SKUAS.}

By T. E. BUCKLEY, M.A., F.Z.S.

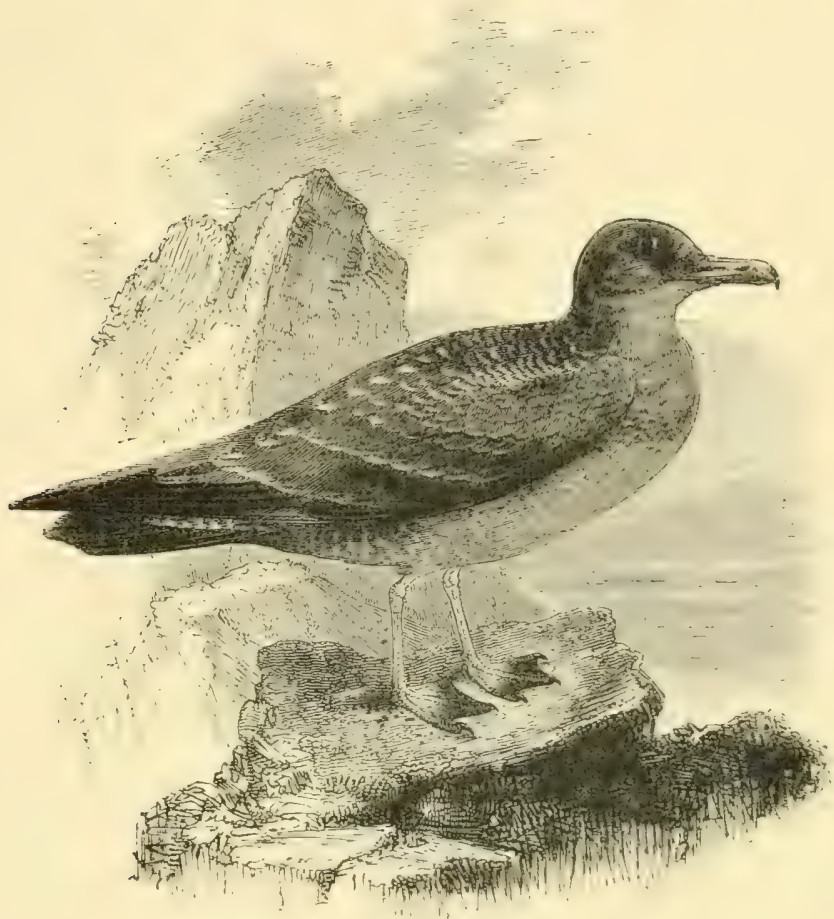

\section{Name.-SKUA.}

$$
\text { Order-Gaviz. Family-Larida. Sub-Family-Stercorariinæ. }
$$

Four Species are included in this Genus, viz. :-

$\begin{array}{ll}\text { Stercorarius catarrhactes }\left(L_{0}\right) . & \text { Great Skua. } \\ \text { Stercorarius pomatorhinus (Temm). } & \text { Pomatorhine Skua. } \\ \text { Stercorarius crepidatus (Banks). } & \text { Richardson's Skua. } \\ \text { Stercorarius parasiticus (L.). } & \text { Buffon's Skua. }\end{array}$

\section{General Description.}

Great Skua.-The general colour of the whole bird is dark brown, mottled on the upper parts with a dull white, under parts rather lighter in colour. When looking

Illustration, by kind permission of Messrs. Gurney \& Jackson, from "Manual of British Birds," by Mr. Howard Saunders, 
down on one flying, there is a very conspicuous patch of white nearly in the centre of each wing, caused by the white colour of the bases of the quills. Bill hooked and black; legs and feet black, with hooked and sharp claws. Length, 24 to 25 inches; wing, 16 inches. The sexes are alike in colour, and the young only differ from the adult in the greater freshness of the plumage.

Pomatorhine Skua.-Front and crown of head, sooty black; neck, white, with straw coloured, sharp-pointed feathers; upper parts, chiefly umber brown, the two middle tail-feathers projecting four inches, and being twisted vertically; breast, dull white ; flanks and abdomen, brown. Length, 21 inches; wing, 14 to $14 \frac{1}{4}$ inches. Younger examples have a brown pectoral band, under parts more or less striped, barred tail coverts, and central feathers but little elongated. The bird of the year is brown, mottled and barred with dull rufous.

Richardson's SkUA. - There are two forms of this species, a dark and a light race. The adult of the former is wholly of a sooty colour; the light race is very dark brown or sooty on the back, the chin light, then a dark band, and the rest of the under parts white; the nape of the neck yellowish; this latter is seen at times in the dark form. In both forms the two middle tail feathers project from $1 \frac{1}{2}$ to 2 inches beyond the rest, and the quills of all the primaries are white. Whole length, 20 inches. Young birds, dark above, light below, and mottled all over.

Buffon's SKuA.-Crown of head, dark brown; neck, nearly encircled with buffish yellow; back, brownish grey; under parts, white; two central tail feathers about 9 in. longer than the others. Length, including central tail feathers, 23 in. Bill, dark horn colour; legs, slate grey ; feet, black. Immature birds are barred with greyish brown and white on both under and upper parts, especially on the breast, flanks, and tail coverts. At all ages, only the quills of the two outer primaries are white.

\section{Where, when, and in what numbers found.}

All four species wre found on migration along the British coasts, but are much commoner on the east side than on the west, and are far more abundant during the autumn than the spring migration. Two species breed in the British Isles: the Great Skua in Shetland only; the Richardson's Skua in Orkney, Shetland, the Outer and Inner Hebrides, and one or two places on the northern mainland. None of the species can be called resident in the strict sense of the word, though a few occur in the south during winter. In Ireland all the species are rare, only Richardson's Skua being a periodical visitor.

\section{Food.}

Generally fish, which they procure mostly by chasing gulls and terns, and forcing them to disgorge, adroitly catching it before it reaches the water. The Great Skua is more carnivorous, preying on otber birds, mostly gulls, but both the Pomatorhine and Buffon's Skua also prey on the Lemming, a small northern and migratory rodent; the latter species also feeds on crowberries in the summer.

\section{Characteristics.}

The great characteristic feature in the Skuas is the way in which they live by chasing gulls, and feeding on the fisk disgorged by them. They make their nests in open ground, amongst heather or grass, and usually lay two eggs of a brown colour, spotted with darker brown. They swoop down on anpone who approaches their nest with great rapidity, 
and though rarely hitting, the rush and wind of their wings is rery startling when the attack: is made from behind and unperceived.

\section{Protection.}

Wild Birds Protection Act, 1880.-These birds appear in the Schedule, which applies to every county in England, Scotland, and Ireland. Any owner, occupier, or other person, taking, lilling, ete., a Skua during close season, * or possessing or selling a Skua after 15th March, is liable to a penalty of $£ 1$ for each bird.

\section{Wild Birds Protection Act, 1894.-The eggs are protected in the following counties :- \\ Great Skua or Bonxie.-Scotland : Zetland. \\ Richardson's Sliua.-Scotrand : Argyll (Isles of Islay, Colonsay, Coll, and Tiree); Zetland.}

Any owner, occupier, or other person, taking or destroying eges of specified skuas in abore. named places, is liable to a penalty of $£ 1$ for each egg.

Wild Birds Protection Act, 1896.--In addition to any penalty under the Act of 1880, the Court may now order an trap, net, snare, etc., used by the offender to be forfeited.

\section{Remarks.}

Unless especially looked for, Skuas are not hirds at all likely to be met with by the ordinary individual except he invades their breeding haunts. Visitor's to the seaside, however, more especially when engaged in the exciting sport of hand-line fishing in the autumn, may have their attention drawn to them when one of these birds shows itself in its most characteristic manner. Perhaps the fish are not taking very well, and he is idly watching a flock of gulls hovering over a shoal of small fish, when a dark-plumaged bird passes the boat with a very hawli-like flight, and dashes into the assembled birds. Instantls there is a general stampede, but the Skua (for such is the dark, hawk-like bird), having marked a gull or tern with his maw full of fish, goes straight for it. Up and down, trying to escape in every possible way of flight, goes the gull, persistently followed by the sliua, getting an occasional blow if obstinate, until with a loud shriek of disgust it ejects its hard-earned pres, when the skua, shooting downward, catches the morsel before it reaches the water, and almost invariably goes straight away with it. The bird thus seen is grenerally the commonest of all the species, Richardson's Skua.

If you invade this same bird's haunts when breeding, and approach his nest, more especially if you have a dog with you, he will boldly advance to the fray. The dog will be the first one to suffer, and if not used to their ways, after one or two unsuccessful attempts to catch the bird as he swoops down on him, will give it up, and keep close to your heels in a state of terror at such an unusual attack, a complete upsetting of his preconceived notion of anything with feathers on it. Then comes your turn, and although you may be quite used to this style of treatment, yet the sharp whish and rush of air, with perhaps a slight touch of a wing, at times when you are not thinking of it, eauses an involuntary shiver and ducking of the head. They are fiue, bold birds, and well worth watching in their breeding haunts.

Curiously enough, although they attack gulls in the manner before described, ret both parties breed together. One place in Orkney we came across was covered with nests of the Lesser Black-backed Gull, and a large number of Richardson's Sliuis' nests were scattered

* Generally from 1st March to 31 st July, but in some counties from 1 st February to 31 st August in each year. A further period may be obtained through the Act of 1896. 
amongst them. The birds were of all the different colours that these Skuas affect, from sooty black to more than half white, one or two showing a good deal of white on the wing.

The only other species that breeds in the British Isles is the Great Skua. Always restricted in its breeding haunts (only one or two places in Shetland being occupied by it), the bird having been considered " rare," has suffered accordingly. Indeed, only a few years ago its numbers were reduced to a very few pairs, but now, thanks to the fostering care of the Edmonstons of Unst, and the Traills of Foula, they are well on the increase, and as popular interest and sympathy have been enlisted on their behalf we may consider their position as pretty well established.

If Richardson's Skua is hawk-like in its flight, the Great Skua is decidedly more eaglelike, and I was struck, when sitting down watching the birds flying below me, at their strong resemblance to a young Sea Eagle that had had the ends of its wings and tail docked. Their behaviour when near the nests is just the same as the Kichardson's Skua I have just described, though they attack you more from the front, and more often come at you skimming along the ground, rising right into your face with their legs and feet stuck out straight before them, than with a downright swoop. They are not sociable with other birds at their nesting grounds, lreeping quite to themselves, and, as far as I could see, allowing no other birds to nest in the area in which their own nests were placed. These are large and somewhat untidy heaps of dried grass, hollowed out in the centre, while those of Richardson's Skua are merely slight hollows in the ground, generally among short heather, with a slight lining of grass ; in each case the number of eggs is almost invariably two. These are usually dark brown in the ground colour, sometimes of a light greenish brown, and are marked with darker spots and blotches, mostly at the larger end.

The other two species being aliens as regards their domestic economy, we need say no more here on that subject, except that they are very much the same as the two already mentioned. In the autumn, howerer, the Pomatorhine Skua is a by no means infrequent visitor to our coasts, these being subject at times to an irruption, a notable example of this being the year 1879, when they were recorded in vast numbers from all parts of the British Isles, appearing literally in thousands off the Yorkshire coast. We may add that they appear in summer off the coast of Lewis; most of the birds seen there in June being adults in full breeding plumage. The Buffon's or Long-tailed Skua, is the rarest of the genus in the British Isles, more especially in the adult state.

What part the Skuas take in the economy of Nature it is not easy to say, but no one who observes birds can fail to be struck with their interesting ways, both "at home" and abroad. T'hey seem to be playing at gulls turning into Hawks, and very well they act their parts, and with no lack of success.

One of the local names of the Sliuas in Scotland is "Dirty Allan," from their habit, as described, of eating the fish disgorged by the gulls they chase. In Yorkshire they are called "Murrylanes," sometimes spelt "Murrel-hens," but the derivation of the word is obscure.

Educational Series.-No. 1.-OWLS. No. 2.-WOODPECKERS. No. 3.-STARLING. No. 4.SWALLOWS. No. 5.-KINGFISHER. No. 6. OSPREY. No. 7.-DIPPERS. No. 8.-NIGHTJAR. No. 9.-TITMICE. No.10.-KESTREL. No. 11.-PLOYERS. No.12.-TERNS. No.13.-WAGTAILS. No. 14.-CHOUGH. No. 15.-JAY. No. 16.-SKUAS.

Others in course of preparation.

Copies of the above may be obtained from the Society's Publishing Department, Knowledye Office, 326, High Holborn, W.C., or from the Hon. Sec., Mrs. F. E. Lemon, Hillerest, Redhill, on the following terms:-Post free : three copies of any one number of the Series, 1d.; one dozen, 3d.; 100, 1s. 6d. Assorted packets, one copy of any six numbers, $2 \mathrm{~d}$; one copy of any twelve, or two copies of any six numbers, $4 \mathrm{~d}$.; or 50 assorted numbers, $1 \mathrm{~s}$. Special terms for larger quantities to County Councils, the Constabulary, and Schools.

The Society's Publishing Office, Knouledge, 326, High Holborn, London, W.C. 1897. 


\section{Soriety for the protertion of gairdo.}

EDUCATIONAL SERIES. Edited by H. E. DRESSER, F.L.S., F.Z.S.

\section{No. 17.-FLYCATCHERS. \\ By JOHN R. B. MASEFIELD, M.A., Vice-President North Staffordshire Field Chib.}

"The Flycatcher is of all our summer birds the most mute, and the most familiar."-Gilbert White.

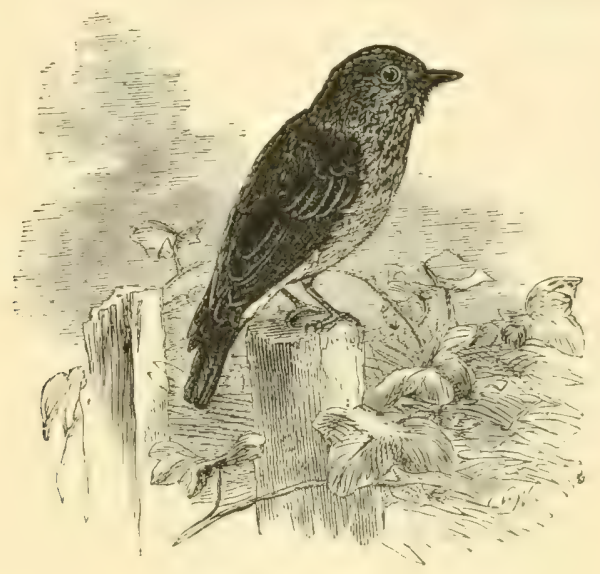

FLTCATCHER.

\section{Name.-FLYCATCHERS.}

Family-Muscicapidx.
Genus-Muscicapa.
M. grisola.
M. atricapilla.
Spotted Flycatcher.
Pied Flycatcher.

\section{General Description.}

Spotted Flycatcher. - The male scarcely differs from the female in plumage: liead and back light brown, with a few darker brown streaks on the top of the head; wings and tail darker brown; breast dull white and chin purer white, aud both spotted or with short streaks of dark brown; under parts white; legs, toes, and claws very dark brown, almost black; irides hazel, bristles around the base of the beak; beak broad at the base, dark brown, and curved near the tip of the upper mandible. The greater portion of the feather's of the foung are tipped with light buff, giving the bird a truly "spotted" appearance. In autumn, just previous to migration, the young assume a more adult plumage, only much lighter in colou. generally and still retaining a few spotted feathers. Total length, $5 \frac{1}{2}$ in.; wing, $3 \frac{1}{8}$ in. ; tail, $2 \frac{1}{4}$ in.

Illustration by Joseph Wolf, from "British Birds in their Haunts", by kind permission of the Society for Promoting Cliristian Knowledge. 


\section{$\left[\begin{array}{ll}2 & ]\end{array}\right.$}

Pied Flycatcher.-Forehead white; top of head, nape, back, and upper tail feathers, black; other tail feathers partially edged with white; outer wing coverts black; smaller wing coverts edged with white; beak, legs, toes, and claws black ; irides dark brown; breast and lower parts of body white. The female is without the white forehead, and of a much browner black where black in the male; wing coverts edged white; under parts dull white. The young are partially spotted with dark brown. Total length about 5 in.; wings, 3 in.; tail, 2 in.

\section{Where, when, and in what Numbers found.}

The Spotted Flycatcher. - A common summer migrant, arriving about the second week in May and leaving our shores again about the middle of September, or sometimes as late as October. Very generally distributed throughout the British Isles, but becoming parer towards the North of Scotland, and somewhat local in Ireland.

The Pied Flycatcher. - Also a summer migrant to the wilder parts of the North and North-Eastern Counties of England, and frequently met with in the Lake District and in the valleys of the mountainous parts of Mid and North Wales. This bird also occurs, and occasionally breeds, in the Midland Counties of England and in Scotland, and has been met with a few times in Ireland. It arrives in April, leaving again in September.

\section{Food.}

Both of these Flycatchers feed exclusively on insects, although an instance has been recorded of the Spotted Flycatcher feeding on earth-worms when pressed by hunger in cold weather. The value of both species to the gardener and farmer is

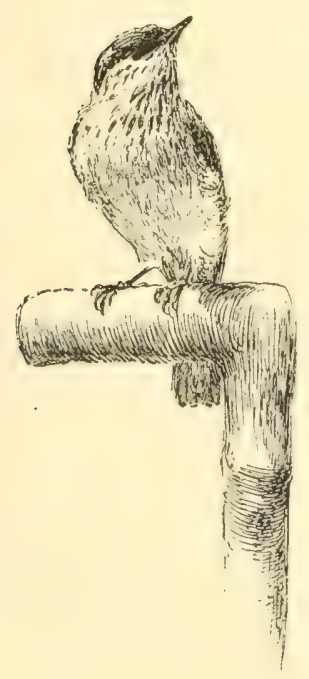
inestimable. An unfortunate idea that Flycatchers occasionally feed on ripe cherries has never been substantiated or proved, and such a report has, no doubt, arisen from the Flycatchers feeding on the flies and other insects which are attracted to the ripe fruit, and this has unfortunately given the Spotted Elycatcher the local name of "cherry sucker" in Kent. The food of these birds must be in a living state or just killed, or they will not take it.

\section{У. Characteristics.}

The Spotted Flycatcher is, as Gilbert White most truly states, of a "familiar" and trusting nature, frequenting the homes and haunts of man, orchards and lawns. It may easily be identified by its habit of perching on a dead branch, a wooden or iron railing, or some other open or conspicuous perch from which it may clearly view the flies and other insects flying near, at which it makes a sudden dash, hovering momentarily while seizing its prey with unerring aim, with a distinct snap of the beak, and then returning again to its station to watch for more. This will often be repeated time after time until the insects in that near vicinity have been cleared away, and then the little bird will move off to another advantageous perch. The Spotted Flycatcher is a late as well as early feeding bird, often catching moths and beetles in the twilight and again being on the alert with the early dawn. When feeding its young, this bird sometimes captures a number of insects, holding them all in its beak until visiting the nest. Although it has a little, low song, it is seldom heard, and Gilbert White accordingly describes it as "the most mute of all our summer birds." Its ordinary note is a weak chirp resembling "tic, 


\section{$\left[\begin{array}{ll}3 & 3\end{array}\right]$}

tic," but its alarm note when anyone approaches the nesting place is a sharp call resembling the words "E-gy̆pt, $\bar{E}-g \breve{y p t, ~} \bar{E}$-gy̆pt" quickly and sharply pronounced, and varied by a sharp "chŭck, chŭck," the bird at the same time becoming rery excited, and with raised crest often approaching within a few feet of the intruder and endearouring to draw away his attention from the nest.

The Pied Flycatcher. - The male of this bird has a short, low song, and its habits generally, and especially its mode of capturing its food, are very similar to those of the Spotted Flycatcher, from which, however, it is easily distinguished by well-marked and distinct black and white plumage.

A description of the nests and nesting habits of the Flycatchers will be found in paragraph VII.

\section{Protection.}

Wild Birds Protection Āct, 1880.-This bird does not appear in the Schedule to the Act, but has been added in the following counties and county boroughs:-

Spotted Flycatcher.-England : Barrow-in-Furness (C.B.) ; Lancashire ; Chester (Hundred of Wirrall); Leicester; Rutland; Salop; Stafford; West Suffoll; Worcester; Isle of Wight; East Sussex; Hastings (C.B.) WaLes: Brecon. Scotrand: Fife (Tentsmuir).

Pied Flycatcher. - England : Barrow - in - Furness (C.B.) ; Cumberland ; Bucks ; Leicester ; Rutland; Stafford; Worcester; Salop ; East Sussex; Hastings (C.B.). WALES: Brecon.

In these counties any owner or occupier, or other person, taking, killing, etc., any Flycatcher during close season,* or possessing or selling one of them after 15th MIarch, is liable to a penalty of $£ 1$ for each bird. In all other places, anyone other than the owner or occupier of land, or his agent, taking, lilling, etc., during close season, or possessing or selling a Flycatcher after 15 th of March, is liable to a penalty of $5 \mathrm{~s}$. for each bird. counties :-

Wild Birds Protection Act, 1894.--The eggs are protected (1897) in the following

Spotted Flycatcher.-England Leicester; Salop; West Suffolk; Warwick; Worcester; London (including Middlesex and Metropolitan Police District). Wales: Brecon; Pembroke. Scotland : Fife (Tentsmuir).

Pied Flycatcher--England : Cumberland; Barrow-iu-Furness (C.B.); Durham; Leicester; Salop; Warwick; Devon; London (including Middlesex and Metropolitan Police District). Wales: Brecon.

Any owner, occupier, or other person, taking or destroring the eggs of thest birds in the abore places is liable to a penalty of $\mathfrak{E l}$ for each egg.

Wild Birds Protection Act, 1896. - In addition to any penalty uncler the Act of 1880, the Court may now order any trap, net, snare, ete., used hy the offender to be forfeited.

The Spotted Flycatcher is protected all the year round in the Comnties of Stafford; Isle of Wight; London; Middlesex and Essex; and in the County Boroughs of Cardiff

* Generally from 1st March to 1st August; but in some counties from 1st February to 1st September in each year. A further period is obtained through the Act of 1896. 


\section{$\left[\begin{array}{ll}4 & ]\end{array}\right.$}

and Kingston-upon-Hull; and the Pied Flycatcher in the Counties of Stafford; London; Middlesex and Essex; and in the County Boroughs of Cardiff, Kingston-upon-Hull, and Hastings.

\section{Remarks.}

By reason of the familiarity of the Spotted Frycatchen, and from its habit of building its nest near the haunts of man, in holes in walls, on a sheltered ledge, on a beam or other woodwork, on a branch of a tree against the trunk, behind the hinge of a door, or on a branch of a tree trained against a house or other building, this bird may easily be provided with an artificial nesting place, and so attracted to build its nest upon or near our houses, and thus afford us the great pleasure of watching its nidification and mode of feeding its young in its natural freedom and liberty. For this purpose a little wooden bracket or shelf, placed in the angle of two walls, under the projecting eaves, or in the corner of a window or door frame, is all that is necessary. The sketch below shows the most convenient shape of such a bracket, of which the front ledge is semi-circular, and about an inch and a half high, and should be covered with bark, virgin cork, or moss. The holes at the sides show where nails are driven to support the bracket. The sides are about four and a half inches in length. Holes should be

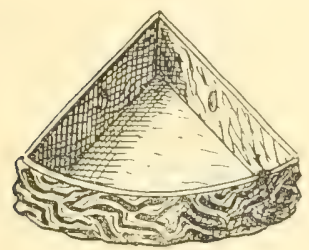
bored in the bottom for drainage. A pair of Flycatchers have used one of these nesting shelves for many years, and have often reared two broods in one year. Another attractive nesting place may be formed by cutting out half a brick from a wall, some eight to nine feet from the ground. A further inducement to attract this bird to the nesting place is to erect a stick with a cross perch in an open situation, such as the centre of a lawn at a short distance from the nest, and the birds will soon take advantage of this perch from which to "hawk" after the insects flying around, and the parent birds will place their newly flown young on such a perch and feed them there. The nest of the Spotted Flycatcher is made of moss and fibrous roots, lined with horse hairs and a few feathers, wool, leaves, etc. The eggs are four to six in number, the ground colour light greenish blue, or bluish cream blotched or streaked more or less with rusty red.

The Pred Flycatcher's favourite nesting place is a hole in a tree or wall. The nest is made of fine roots, grass, hair, and dead leaves. The eggs are five to eight in number and of a delicate light greenish blue in colour.

This Illustration by kind permission of Messrs. 'Taylor Brothers, Leeds, from "Wild Bird Protection and Nesting Boxes," by Mr. John R. B. Masefield, M.A.

Educational Series.-No. 1.-OWLS. No. 2.-WOODPECKERS. No. 3.-STARLING. No. 4.-SWALLOWS. No. 5.-KINGFISHER. No. 6.-OSPREY. No. 7.-DIPPERS. No. 8.-NIGHTJAR. No. 9. -TITMICE. No. 10.-KESTREL. No. 11.-PLOVERS. No.12,-TERNS. No. 13.-WAGTAILS. No. 14.-CHOUGH. No.15.-JAY. No. 16. -SKUAS. No. 17.-FLYCATCHERS. No. 18,-NIGHTINGALE.

Others in course of preparation.

Copies of the abore may be obtained from the Society's Publishing Department, Knowledge Office, 326, High Holborn, W.C., or from the Hon. Sec., Mr's. F. E. Lexon, Hillcrest, Redhill, on the following terms:-Post free: three copies of any one number of the Series, $1 \mathrm{~d}$; ; one dozen, $3 \mathrm{~d} . ; 100,1 \mathrm{~s} .6 \mathrm{~d}$. Assorted packets, one copy of any six numbers, 2d.; one copy of any twelve, or two copies of any six numbers, 4d, or 50 assorted numbers, 1s. Special terms for larger quantities to County Councils, the Constabulary, and Schools.

The Society's Publishing Office, Knowledge, 326, High Holboru, London, W.C. 1897. 


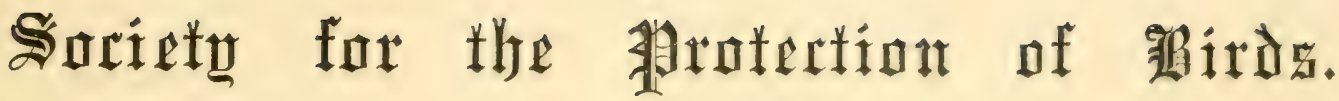

EDUCATIONAL SERIES. Edited by H. E. DRESSER, F.L.S., F.Z.S.

\section{No. I8.-NIGHTINGALE. \\ By J. H. ALLCHIN, \\ Bentlif Curator, The Mnseum, Maidstone.}

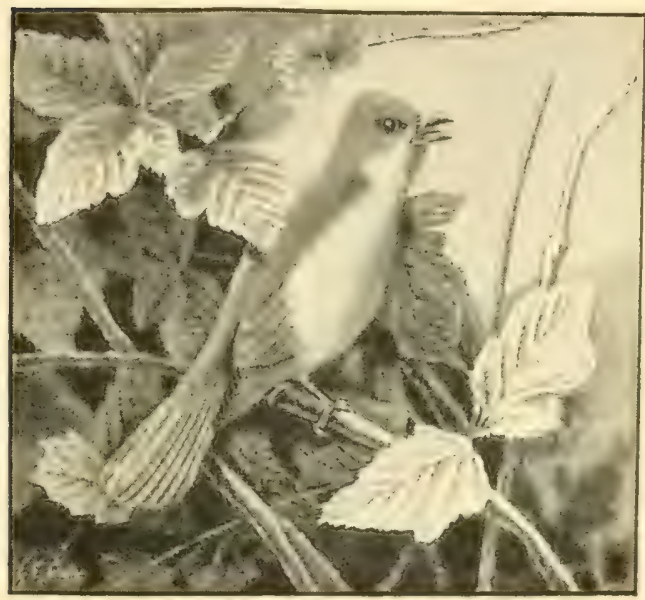

THE NIGHTINGALE.

\section{Name,-NIGHTINGALE.}

Family-Turdida.

Genus-Danlias. D. Luscinia. Nightingale.

\section{General Description.}

In the adult birds the upper parts are russet-brown shading into reddish chestnut on the tail-coverts and tail, the colour of the latter being verr noticeable on flight; the cheeks, throat, and under surface of the body are a greyish white, the flankis and breast being tinged with buff ; bill, legs, and feet, brown; iris hazel. Total length, 6 inches. The female is similar to the male in colour, but slightly smaller in size. The young in their first plumage are a duller and more sober brown than the adults, and are speckled over with ochreous brown marlings, which may easily cause them to be mistalien for the young of the Robin, to which bird the Nightingale is a close ally.

\section{Where, when, and in what numbers found.}

The English Nightingale is the only representative in this country of a genus which includes three species. The distribution of the bird is confined entirely to England, and even here its range is limited, for it does not appear to go farther north than Yorlshire, 
whilst in the western counties Devoushire and the Welsh border are the extent of the bird's range as a rule, although a straggler does occasionally wander a little more to the west and creates a large amount of interest amongst the music-loving people of Wales. In Science Gossip of 1894 the visit of a Nightingale to North Wales is recorded, and the intense interest which the bird's advent excited is described.

As an immigrant the Nightingale comes to our shores about the middle of April; in the neighbourhood of Maidstone, where I have taken observations for several years, the dates on which I have first heard the bird have varied from Apri] 14th to the 24th, and the latest recorded date on which I ever heard the call-note was August 30th, 1889.

In the autumnal migration the Nightingale leaves our country about the commencement of September, passes southward through Europe, and winters as far south as Abyssinia.

\section{Food.}

Insects of various linds, grubs, caterpillars, ants and their eggs, the last named being an especially farourite diet of the Nightingale, who also feeds on earwigs, spiders, etc.

The young are fed chiefly with small green caterpillars.

\section{Characteristics.}

The Nightingale in its movements and habits much resembles its near relative the Robin; the action of flight in the two birds is very similar, and the former bird also has the same custom of flitting along a hedgerow, or by the side of a wood, from which it occasionally darts down to the ground to pick up a wandering ant or beetle, or some other morsel of food, and at the same time it jerks its tail up and down after the manner of the Robin. When the bird is perched on the bough of a tree, pouring forth its wonderful song, the head is thrust slightly forward, the tail at the same time being rather depressed. As a songster the Nightingale sings both by day and night, and the day and night singers are not separate birds, as was thought to be the case at one time.

\section{Protection.}

Wild Birds Protection Act, 1880.-This bird appears in the Schedule, which applies to every county in England, Scotland, and Ireland.

Any owner, occupier, or other person taking, killing, etc., a Nightingale during the close season,* or possessing or selling a Nightingale after March 15th, is liable to a penalty of $£ 1$ for each bird.

Wild Birds Protection Āct, 1894.--The eggs are protected at present (1897) in the following counties, or specified breeding areas in counties :-

England.-Yorlishire (W. Riding); Bedford; Gloucester' Huntingdon; Leicester ; Lincoln (Kesteven and Lindsey); Northampton; Salop; Stafford; West Suffolk; Warwick; Worcester; Devon; Herts; Kent; London (including Middlesex and Metropolitan Police District); and the County Boroughs, Huddersfield, Hastings, and Cardiff.

\section{Wales.-Brecon, Glamorgan, and Pembroke.}

Any owner, occupier, or other person taking or destroying the eggs of the Nightingale in either of the above-named counties or specified areas is liable to a fine of $£ 1$ for each egg.

The eggs, which are generally four or five in number, but occasionally six, are olivebrown or olive-green in colour; and when of the former tint are not altogether dissimilar from the colour of the bird itself.

* Generally from 1st March to 1st August; but in some counties from 1st February to 1st September in each year. A further period is obtained through the Act of $\mathbf{1 8 9 6 .}$ 
Wild Birds Protection Āct, 1896. - In addition to any penalty under the Act of 1880 , the Court may now order any trap, net, snare, etc, used by the offender, to be forfeited.

The Nightingale is protected all the year round in the counties of Stafford, Essex, London, Middlesex, and the County Borough of Kingston-upon-Hull.

In connection with the protection of the Nightingale it is leasing to be al)le to remark that farmers and fruit growers are agreed that the bird should be most fully protected; not, merely from a sentimental point of view, but becanse of its usefulness als an insect-eating bird. One large fruit grower in this district, who has very lindly supplied me with valuable information concerning the feeding labits of some of our wild birds, wrote:- "I should like to see a heavy penalty enforced against anyone destroying these birds"-referring to the Nightingale and several other British birds enumerated in a list.

\section{Remarks.}

At the time of the immigration of the Nightingales to this country the male birds precede the females by a few days, and at once commence their song. by that means atiacting their mates on the arrival of the latter, and the song is continued during the period of incubation, after which the energies of both pareuts are deroted to feeding the roung: it occasionally happens that the song is continued to a later period of the season, and in 1588 I heard a Nightingale singing as late as July the 15 th, which was an exceptionally late date; perhaps it is scarcely necessary to add that the notes were very hoarse and wanting in tone.

The nest of the Niglingale is built on or close to the ground, amongst a thick tangle of undergrowth in shrubberies, copses, and woods; and as the bird itself differs from all our other native birds by virtue of its song, so also does its nest differ from other nests in construction, being a most picturesque and heatiful structure, composed chiefly of dried grasses commingled with dead leares, those of the oak being more frequently chosen; and at first sight the nest may easily be passed by as a bundle of withered foliage": the interior, however, is much more neatly finished, being lined with fiuer grasses and borsehair.

I am inclined to think that the male bird participates in the incubation of the egus, and am induced to believe that to be the case through the following instance which came uncler my notice a few years ago, when I was living in one of our Kentish villages, where my garden was visited year after year by a pair of Nightingales, which always nested close by; one year they had their nest in a small copse that was not more than a dozen yards from the house, so that I had frequent opportunities to observe their movements. One day, whilst I was watching the female as she hopped about on the ground, feeding, $L$ saw that when she went in the direction of the nest she was joined by her mate, who carre from the copse shaking and ruffling his feathers, and stretching himself, in the manner of birds when they leave their eggs after a spell of sitting; he then perched on is neighbouring tree, sitve a short burst of song, and flew away, and the hen at the same time went to the nest.

To many people the Nightingale is nothing more than a voice in the wood, a sprite in the coppice or wayside covert, and it is really a matter for wonder to meet such a liure number of individuals-eren amongst those who live in the country-who do not know the bird apart from its song, and who express their surprise when they first see a specimen in a collection, or have the living bird pointed out to them in the mitst of its haunts; and they appear to consider it a marvellous matter thist such a plainly colourerl, sober-loolings bird should possess so powerful a gift of song.

And jet the Nightingale is not altugether a shy bird, but soon becomes accustomed to the presence of man near its haunts, and when properly approaclied will allow an olsserver to get very near to it, as I have often done in the garden of my former cottage liome at sutton 
Valence, where the Nightingales were as bold and familiar as the Robins, frequently coming to within a few feet from me in order to feast on the insects which the spade turned up.

The Nightingale is without doubt the special favourite amongst our British wild birds, not on account of its beauty-although it does not fail in that respect either in elegance of form or in colour-but owing to its wonderful power of song, which caused honest Isaak Walton to enumerate the bird amongst "those little nimble musicians of the air that warble forth their curious ditties, with which nature hath furnished them to the shame of art" ; and to speak of it in the following terms:- "But the Nightingale, another of my airy creatures, breathes such sweet loud musick out of her little instrumental throat, that it might make mankind to think miracles are not ceased. He that at midnight, when the very labourer sleeps securely, should hear, as I have very often, the clear airs, the sweet descants, the natural rising and falling, the doubling and redoubling of her voice, might well be lifted above earth, and say, Lord, what musick hast thou provided for the Saints in Heaven, when thou affordest bad men such musick on Earth ?"

Only those who have had the good fortune to hear these birds when in the fulness of their singing powers can appreciate the charm which enters into the listener's feelings when surrounded by a choir of these feathered songsters; a charm which is enhanced and impressed more deeply into the hearer's enjoyment if the occasion be at night, when all other sounds are hushed and stilled, save the gentle soughing of the wind through the trees, which bears on its waves the music of the voices of the night.

Unfortunately this bird's gift of song has rendered it a great favourite amongst bird fanciers, and one of its chief enemies in this country has been that curse of the wild bird life of England, the lazy, hulking birdcatcher, who, until the Wild Birds Protection Acts came into operation, spread his net annually and captured the Nightingales in large numbers on their first arrival in England (when the males can be more easily talien), and sold them for high prices, according to the degree of their power of song. The late Mr. J. Gould, in his work on the "Birds of Great Britain," wrote very strongly against the practice, and said :"No bird is so easily trapped, and no one is more difficult to keep in confinement; ninetenths, at least, of those that are taken die within a month after their capture; while those that survive pass a miserable existence in a darkened prison, never again to chant over the drooping bluebell, or cheer the loiterer along the green lanes of our faroured island." We trust, however, that the day for such a lament has passed, and that in the future the Nightingale, whose advent is alwitys looked forward to with pleasurable expectancy, may find in our land a sanctuary wherein she may rear her young in safety.

For a few of the details in this paper I am indebted to Dr. Bowdler Sharpe's "Handbook to the Birds of Great Britain."

Educational Series.-No. 1.-OWLS. No. 2.-WOODPECKERS. No. 3.-STARLING. No. 4.SWALLOWS. NO. 5. KINGFISHER. No. 6. -OSPREY. No. 7.-DIPPERS. No. 8. -NIGHTJAR. No. 9.-TITMICE. No. 10.-KESTREL. No. 11 -PLOYERS. No.12.-TERNS. No. 13.-WAGTAILS. No. 14.-CHOUGH. No.15.-JAY. No.16.-SKUAS. No.17.-FLYCATCHERS. No. 18.-NIGHTINGALE.

Others in course of preparation.

Copies of the abore may be obtained from the Society's Publishing Department, Knowledge Office, 326, High Holborn, W.C., or from the Hon. Sec., Mrs. F. E. Lexon, Hillcrest, Redhill, on the following terms :-Post free: three copies of any one number of the Series, 1d.; one dozen, 3d.; 100, 1s. 6d. Assorted packets, one copy of any six numbers, 2d.; one copy of any twelve, or two copies of any six numbers, $4 \mathrm{~d}$; ; or 50 assorted numbers, 1s. Special terms for larger quantities, and to County Councils, tho Constabulary, and Schools.

The Society's Publishing Office, Knowledge, 326, High Holborm, London, W.C. 1897. 


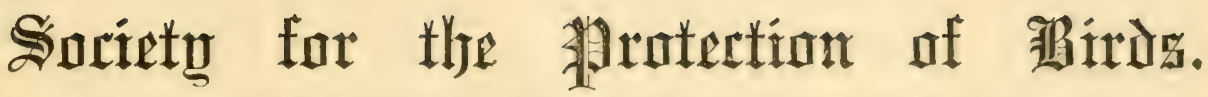

EDUCATIONAL SERIES. Edited by H. E. DRESSER, F.L.S., F.Z.S.

No. 19.-GULLS.

By HOWARD SAUNDERS, F.L.S., F.Z.S.

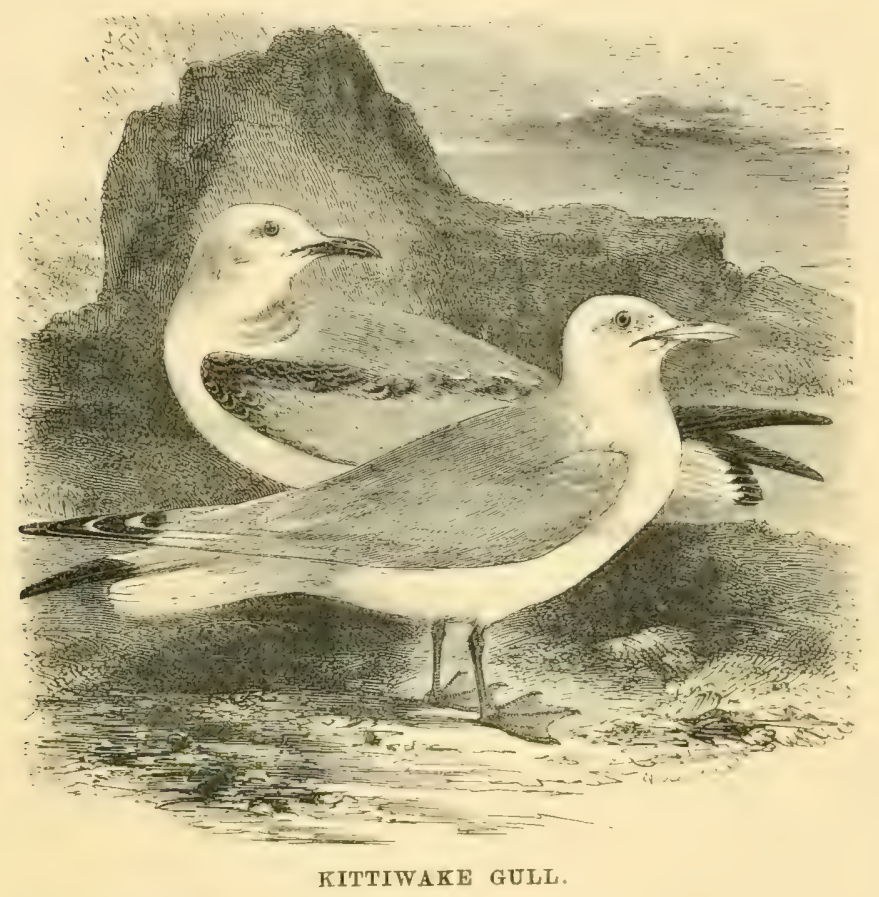

I. Name.-GULLS.

Family-Laridx.

Sub-Family-Larinæ.

Genus 1.-Larus.

L. ridibundus.

Brown-headed Gull.

L. canus.

Common Gull.

L. argentatus.

L. fuscus.

L. marinus.

Genus 2.-Rissa.

$R$. tridactyla.

Herring Gull.

Lesser Black-backed Gull.

Great Black-backed Gull.

Kittiwake Gull.

\section{General Description.}

All the above Gulls when adult have the underparts and tail white, and both sexes are alike in plumage. Hind toe well developed, except in Rissa. 
Brown-Headed Gult.-Adult in Summer. Hood dark brown; mantle French grey; outer quills characterized by the white centres and the dark margins of the inner webs; an evanescent pink tint on the under parts ; bill, tarsi, and toes blood-red. From autumn to early March the hood is almost absent. Immature, mottled with brown on the mantle, and a band of dark brown near the end of the tail. Total length 16 in., wing 12 in.

Common GuLL.-Larger than the above. Head white; mantle dark grey; outer quills chiefly black, with white "mirrors" near the tips, conspicuous in flight; bill, tarsi, and toes yellow to greenish. In winter the head is streaked with ash brown. Immature, mottled brown; dark tail band; quills dark brown. Total length 18 in., wing $14 \mathrm{in}$. (long for the size of the bird).

Herring-Gold.-Adult. Much larger than the preceding, and mantle pale grey; otherwise not unlike in all stages; bill yellow, with orange at the angle; tarsi and toes flesh-colour. Length 24 in., wing 17 in.

Lesser Black-Backed GUld.-Adult. Mantle varying from very dark grey to black; bill as above; tarsi and toes lemon-yellow; the foot comparatively small, and shorter than the tarsus. Immature, darker than in the Herring Gull, notably as regards the mottlings of the tail. Length of male $23 \mathrm{in}$., wing $16 \mathrm{in}$.; female smaller.

Great Black-Backed Gull.-Mantle deep black; large white " mirrors" near the tips of first and second quills; bill as above in colour, but very large in the male; tarsi and toes flesh-colour, Immature, rather pale coloured in mottlings. Length of male 30 in., wing $20 \mathrm{in}$. ; female smaller.

Kittiwake Gul.L.-Hind toe absent or aborted; bill remarkably decurved. Adult in Summer. Mantle slate-grey; quills black to the tips, an excellent distinction from Common Gull; bill greenish yellow; tarsi and toes blackish. Young, with a black half collar on the nape; a broad black band across the shoulders; much black on the carpal joints and wing-coverts; tail with a terminal black band; bill and tarsi dark reddish brown. Immature, with fainter collar and bands. Isength $15 \frac{1}{2}$ in., wing $12 \mathrm{in}$.

\section{III., IV., V.-See under Remarks.}

\section{Protection.}

Wild Birds Protection Act, 1880.-These birds (with the exception of the Blackbacked Gulls) appear in the schedule which applies to every county in England, Scotland, and Ireland. Any owner, oceupier, or other person taking, killing, etc., them during close season,* or possessing or selling them after 15th March, is liable to a penalty of $£ 1$ for each bird. The penalty in the case of the Black-backed Gull is less.

Wild Birds Protection Act, 1894.--The eggs of all wild birds (including Gulls) are protected in the specified areas of the following counties: Northumberland; York, E. Riding; Cambridge; Chester ; Norfolk ; East Suffolk ; Devon ; Essex ; Kent ; Isle of Wight ; and East Sussex. The eggs of Gulls are also protected as follows:--

Brown-headed Gull.-EngLAND : Cumberland; Lancaster; Barrow-in-Furness (C.B.); Westmoreland; Chester; Devon. Scotuand: Aberdeen; Banff; Dumbarton; Dumfries; Elgin; Kirkcudbright ; Lanark; Nidlothian; Orkney ; Roxburgh, and Wigtown.

Common Gull.-Scotrand : Aberdeen ; Dumfries ; Elgin ; Kirkeudbright, and Wigtown.

* Generally from 1st March to 31st July; but in some counties from 1st February to 31st August in each year, A further period may be obtained under the Act of 1896 (q.v.) 
Herring-Gull. - Scotuand : Aberdeen.

Lesser and Great Black-backed Gulls.-EngLAND : Devon.

Kittiwake.-England: Northumberland (Farne Island). Scotbaxd: Aberdeen ; Dumbarton; Elgin, and Orkney.

Any owner, occupier, or other person taking or destroying eggs of specified Gulls in the

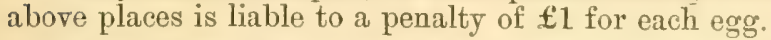

Wild Birds Protection Act, 1896. - In addition to any penalty miler the Art of 1880, the Court may now order any trap, net, snare, dc., used by the offender, to be forfeited.

All the year round.-Under this Act the extension of the period of protection beyond the breeding season may be granted, and orders have been made which give protection all the year round as follows:-

Gulls (all species).-Chester (Hundred of Wirrall) and South Shiclds (C.B.)

Gulls (except Black-backed Gulls).-Devon.

\section{Remarks.}

The Gulls enumerated differ widely in their haunts, habits, and food; for which reason each species requires separate consideration.

The Brown-Headed or Black-Headed Gulu is the most widely distributed; nesting in colonies, on marshes, or near lakes-as at Scoulton Mere, Brigg, in Lincolnshire, etc.-or on flat sandy coasts where marram grass grows; while from autumn to spring it is found along the sea-shore or on tidal and fresh water, as well as on arable land. This is the Gull now so well known on the Thames, and on the waters of St. James' and other Parks; taking food thrown to it, or from the hand, and giving pleasure to many observers owing to its graceful evolutions. Its flight is remarkably buoyant, and it sits rery high on the water. To the farmer it is undoubtedly a benefactor, because it devours large numbers of grubs and worms.

THE "Common" GULL is chiefly entitled to its trivial name in winter, so fir as England is concerned; for it is not known to nest to the south of the Border and the Solway. In Scotland it breeds freely on grassy islands, the sides of lochs, and on slopes by the sea, but seldom, if ever, in localities which can fairly be described as precipitous. It is, in fact, a marsh-gull, but without the black head of the preceding species. It does not go far from land, to which it promptly returns on the approach of coarse weather; while in autumn and winter it may be seen in numbers on the fallows and pastures, picking up grubs and worms. Its utility to the agriculturist is, therefore, undoubted.

The Herring-Gulu is emphatically a frequenter of the sea, though it, also, is to be found inland from autumn to spring. This is really the "Common" Gull of England, and is the species found nesting on most of the precipitous cliffs in the British Islands, while, less frequently it breeds among sand-hills or on salt-marshes. Although it eats insects and their larvæ, it is practically omnivorous, and is a terrible destroyer of the eggs of Guillemots and other sea-birds. It has been an important factor in the extirpation of the Gannet at Lundy Islands It requires no special protection, being quite able to take care of itself. 
The Lesser Black-Backed Golu is rather less addicted to precipitous localities, and is more inclined to select slopes and unarshes for its breeding-places. Its food is similar to that of the Herring-Gull, with, perhaps, a larger proportion of small crabs; but inasmuch as this Gull breeds further inland, it is even more destructive than the preceding species to eggs and young of game and water-fowl. A Lesser Black-backed Gull has been found choked by a duck's egg which it had attempted to swallow.

The Great Black-Backed Guli, is the least numerous of the large sea-gulls; it has, nevertheless, been specially exempted from protection. It is quite "the vulture of the shore"; feeding upon any animal-matter, from the sodden corpses of drowned sailors and fishermen to dead or wounded water-fowl, and even sickly lambs; while it is a great devourer of eggs. Its nest, when on the coast, is usually on some isolated crag, "holm," or stack; but inland lochs also afford breeding-places.

The Kittiwa ke GULl is absolutely innocuous, and amply deserves protection. Its food consists of small fish and other marine animals; while the clamour arising from the immense colonies which frequent our rockiest shores may very likely act as a warning to vessels approaching a dangerous coast in a fog. This is the species which has been slaughtered, under circumstances of horrible barbarity, to provide adornments for ladies' hats. I have watched, day after day, a flotilla of boats procuring plumes for the market; one gang of men shooting, and changing their guns when too hot; another set picking up the birds, and often cutting their wings off and flinging the victims into the sea, to struggle with feet and head until death slowly came to their relief; and I have seen the cliffs absolutely "spotted" with the fledglings which had died of starvation, owing to the destruction of their parents. And it may be accounted unto me for righteousness that, in my indignation, I hove down rocks whenever such an act would interfere with the shooters.

The Act of $18 \varepsilon 0$ was insufficient to protect these poor birds, for it expired on August 1st, just at the time when Kittiwakes were nearly at their best for plumes. Such things are, happily, of the past, for the Kittiwake's wing is temporarily out of fashion, having given way to the plumes of the Egret, called "Osprey" by the trade.

Educational Series.-No. 1.-OWLS. No. 2.-WOODPECKERS. No. 3.-STARLING. No. 4.SWALLOWS. No. 5.-KINGFISHER. No. 6.-OSPREY. No. 7.-DIPPERS. No. 8.-NIGHTJAR. No. 9.-TITMICE. No. 10.-KESTREL. No. 11.-PLOYERS. No. 12.-TERNS. No. 13.-WAGTAILS. No. 14.-CHOUGH. No. 15.-JAY. No.16.-SKUAS. No.17.-FLYCATCHERS. No. 18.-NIGHTINGALE. No. 19. - GULLS. No. 20. - LEAF-WARBLERS. No. 21.-PIPITS. No. 22. - SKYLARK. No. 23.-GREBES. No. 24.-COMMON BUZZARD.

Copies of the abore may be obtained from the Society's Publishing Department, Knowledye Oflice, 326, High Holborn, W.C., or from the Hon. Sec., Mrs. F. E. Lemon, Hillcrest, Redhill, on the following terms:-Post free : three copies of any one number of the Series, 1d.; one dozen, 3d.; 100, 1s.6d. Assorted packets, one copy of any six numbers, 2d.; one copy of any twelve, or two copies of any six numbers, $4 \mathrm{~d}$, , or 50 assorted numbers, $1 \mathrm{~s}$. Special ter $\mathrm{ms}$ for larger quantities, and to County Councils, the Constabulary, and Schools. 


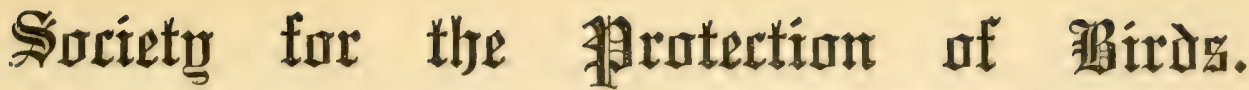

EDUCATIONAL SERIES. Edited by H. E. DRESSER, F.L.S., F.Z.S

\section{No. 20. $-\mathrm{LEAF}=\mathrm{WARBLERS}$.}

\author{
By H. E. DRESSER, F.L.S., F.Z.S
}

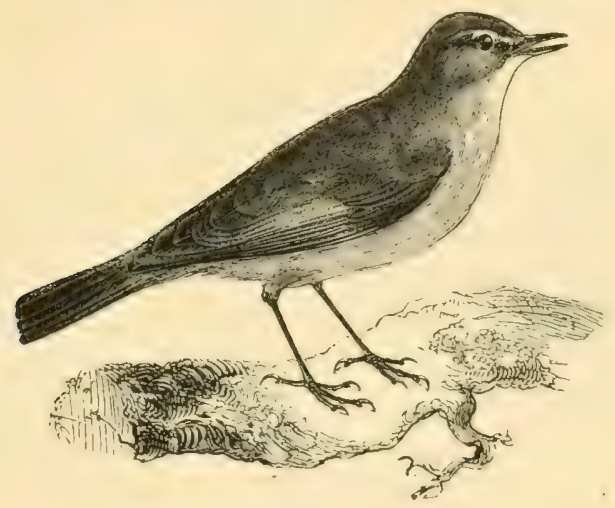

CHIFFCHAFF.

\section{Name.-LEAF-WARBLERS.}

Sub-Family-Sylviinæ.
Genus-Phylloscopus.
1. P. collybita.
Chiffchaff.
2. P. trochilus.
Willow-Wren.
3. P. sibilatrix
Wood-Wren.

\section{General Description.}

Chifgchaff.-Upper parts olive-green, somewhat yellower on the rump; superciliary stripe yellowish, becoming white behind the ear coverts; wings and tail brown externally, margined with olive green; under parts dull white washed with greenish buff; under wing-coverts pale yellow; bill and legs, dark brown; iris, brown. Length about 4.75 inches; wing, 2.51 ; tail, 2.05 ; tarsus, 0.8 ; second quill equal in length to the seventh, and the quills externally emarginate to the sixth inclusive, third and fourth quills longest.

WILLOW-WREN.-Upper parts olive-green, yellower on the rump; superciliary streak yellowish; wings and tail dark brown externally, margined with greenish yellow; under parts yellowish white, tinged with sulphur on the flanks; under wing-coverts, yellowish ; bill, dark brown; legs, light brown; iris, brown. Length, nearly 5 inches ; bill, 0.42 ; wing, $2 \cdot 65$ tail, $2 \cdot 15$; tarsus, 0.8 .2 . The second quill intermediate in length between the fifth and sixth, the third longest, the primaries externally emarginate as far as the fifth. The Willow-Wren may be distinguished from the Chiffehaff by its larger size, yellower colour, paler legs, and the difference in the wing formula and emargination of the primaries.

WooD-WREN.-Upper parts olive-green, tinged with sulphur yellow, the crown and

Illustration, by kind permission of Messrs. Gurney \& Jackson, from "Manual of British Birds," by Mr. Howard Saunders. 
rump yellower; wings and tail slaty-brown externally, margined with yellow; forehead and superciliary streak bright sulphur yellow; sides of head, chin, throat, breast, flanks, and edge of wing, sulphur-yellow ; the rest of the under parts white ; bill, legs, and iris, brown. Total length about 6 inches; bill, 0.5 ; wing, 3.0 ; tail, 2.0 ; tarsus, 0.72 ; first quill short and narrow, 1.8 inch shorter than the second, which is a trifle longer than the fifth ; third quill longest. The females of all three species resemble the males, but are a trifle smaller, and the young birds are rather yellower than the adults.

\section{Where, when, and in what numbers found.}

Chiffehaff. - A sumner visitant, arriving in March and leaving in the autumn. It is very generally distributed in Great Britain as far north as Ross-shire, but is merely a straggler to the Outer Hebrides and Orkneys, and is also common in Ireland in summer. A few winter in the South of England. Its general range is from the Canaries to the Valley of the Volga, and north to within the Arctic Circle, wintering in South Europe, Asia Minor, Persia, and North Africa.

WILLOW-Wren.-Common and generally distributed in Great Britain and Ireland, from April to September, but is rarer in Northern Scotland, and is a straggler to the Orkneys and Shetland. It is found throughout Europe as far up as the North Cape, and as far east in Asia as the Yenesei Valley, wintering in Persia, South Europe, and Africa as far south as the Cape of Good Hope.

Wood-Wren.-From the middle of April to September it is fairly common, but somewhat locally distributed in England, somewhat rarer in Wales, and found in Scotland to Sutherland and Caithness, but is much rarer in Ireland. In Europe it ranges from the far west to the Ural, and as far north as Southern Scandinavia, wintering in Africa as far south as the Gold Coast.

\section{Food.}

All the Leaf-Warblers are insectivorous, feeding almost entirely on the small insects which they pick off the leaves of trees, flies, and insect larvæ, and they but rarely touch berries of any description. Hence they are essentially deserving of protection, inasmuch as they are most useful in destroying many insects that are injurious to the farmer and gardener.

\section{Characteristics, see VII.}

\section{Protection.}

Wild Birds Protection Act, 1880. - These birds do not appear in the Schedule to the Act, but have been added in the following counties and county boroughs :-

Chiffchaff, Willow-Warbler, and Wood-Warbler in EngLand: Lancashire (except the Hundred of Amounderness and Lonsdale south of the Sands); Buckingham; Rutland; East Sussex; Hastings (C.B.). Wales: Brecon. Scotland: Kincardine.

Chiffchaff also in England: Lancashire (remainder of County); Chester (Hundred of Wirrall); Worcester; Peterborough, Soke of ; and Isle of Wight.

Willow-Warbler also in Engtand: Barrow-in-Furness (C.B.). Scotmand: Fife (Tentsmuir).

Wood-Warbler also in Enatand: Barrow-in-Furness (C.B.); Chester (Hundred of Wirrall), Scotland : Fife (Tentsmuir).

In these counties any owner or occupier, or other person, taking, killing, etc., any of 
these birds during close season,* or possessing or selling one of them after 15th March, is liable to a penalty of $£ 1$ for each bird. In all other places, anyone other than the owner or occupier of land, or his agent, taking, killing, etc., during close season, or possessing or selling a Warbler after 15th of March, is liable to a penalty not exceeding $5 \mathrm{~s}$. for each bird.

Wild Birds Protection Act, 1894.-The eggs are protected (1897) as follows :-

Chiffchaff, Willow-Warbler, and Wood-Warbler in ENGLAND : In the specified breeding areas of eleven counties, and in Yorkshire (W. Riding); London (including Middlesex and Metropolitan Police District). WALES: Brecon and Pembroke.

Chiffchaff also in EngLand : Leicester and Warwick.

Willow-Warbler also in EngLAND: Lancaster (south of the Ribble); Leicester; Warwick; Worcester. Scotland : Fife (Tentsmuir).

Wood-Warbler also in ENGind : Lancaster (south of the Ribble); Gloucester; Devon. Scotrand: Fife (Tentsmuir).

Any owner, occupier, or other person, taking or destroying the eggs of these birds in the above places is liable to a penalty of $£ 1$ for each egg.

Wild Birds Protection Act, 1896.- In addition to any penalty under the Act of 1880 , the Court may now order any trap, net, snare, etc., used by the offender to be forfeited.

The Chiffchaff, Willow- and WVood-Warbler, are protected all the year round in the Counties of Stafford; Isle of Wight (except the Willow-Warbler); London; Middlesex and Essex (Metropolitan Police District and Epping, Theydon Bois, etc.); and in the County Boroughs of Cardiff and Kingston-upon-Hull.

\section{Remarks.}

The Leaf-Warblers are essentially woodland birds, frequenting groves, well-wooded gardens, orchards, etc., where they may be seen flitting about amongst the foliage, continually in motion, searching for their insect food. They often visit bushes, should their insect food be there, but prefer the foliage of trees, both conifers and deciduous, and are seldom seen seeking food on the ground. They either pick the insects or larvæ off the leaves and branches of the trees they frequent, or capture gnats and flies on the wing, which they do with great dexterity. The Chiffchaff may be recognized by its note chiff-chaff or chiffychaffy, which is weak but shrill, and is uttered whilst the bird is hopping about amongst the branches. The song of the Willow-Wren is simple and sweet, but not very raried, and its call note is a soft, low whistle, not unlike the syllables veed, weed, but when alarmed or suddenly disturbed it utters a rapid reiterated plaintive note. The alarm note of the WoodWren differs little from that of the Willow-Wren, but its song differs and is clear and sweet, consisting of the syllable chu or chit uttered several times in succession, followed by a shivering note which is audible at a considerable distance. The Wood-Tren is a much shyer bird than either the Chiffchaff or the Willow-Wren, and affects groves where the trees are high, especially beech woods, and where the undergrowth is thick and the ground is damp though not wet. All three species build domed or semi-domed nests, which are almost invariably placed on the ground, on a bank, behind an old tree stump or amongst dense grass. According to Yarrell, Doubleday found the nest of a Chiffchaff in dead fern, at least two feet above the ground, and Hewitson mentions an instance of the nest of the same species being built in some iry against a garden wall; but all the nests I have ever found were placed on the ground, usually in a somewhat

* Generally from 1st March to 1st August; but in some counties from 18 February to 1st September in each year. A further period is obtained through the Act of 1896. 
open spot. Of all three species, the nest of the Wood. Wron is most difficult to find, for it is most carefully concealed amongst the herbage - often in a grass tussock-and the opening is always well hidden from view. The nests of all three species are built of grass bents, sometimes intermingled with a little moss; those of the Chiffchaff and Willow-Wren are well lined with feathers, whereas that of the Wood-Wren is lined with fine grass bents and a little horsehair-never with feathers. Occasionally both the Willow-Wren and the Chiffchaff use a few hairs or wool in the lining of their nests, but feathers form invariably the main portion of the lining. The number of eggs deposited by all these species varies from five to seven, very rarely eight. Those of the Chiffchaff are white, somewhat sparingly spotted and dotted with occasional small violet-grey shell-spots and deep purplish red surface markings; whereas those of the Willow-Wren are white, more or less spotted, dotted, and blotched with pale red, and are also, as are those of the Chiffchaff, occasionally, though rarely, pure white, unspotted. The eggs of the Wood-Wren are white, minutely spotted and speckled with deep purplish red spots, sometimes with a brown tinge, and here and there marked with a few pale purplish grey underlying shell dots; in some eggs the spots are more numerous, and form a wreath round the larger end. In all three species the shell of the egg is thin, and when fresh the yolk shows through.

Besides the above-mentioned three species, others have occurred as rare stragglers during migration. Two of these-the Yellow-browed Warbler, Phylloscopus superciliosus, and Pallas's Willow-Warbler, Phylloscopus provegulus-are very small, scarcely larger than a Golden-crested Wren, and are greenish olive above and white below, the flanks yellowish. The former may be recognized by having a broad yellowish white stripe over the eye, from the base of the bill to the nape, and two conspicuous lemon-yellow bands across the wing; whereas the latter (Pallas's Willow-Warbler) differs from the Yellow-browed Warbler in having also a broad central yellow stripe along the crown, and a broad band of lemon-yellow across the rump. A third species-the Greenish Willow-Warbler, Phylloscopus viridanusresembles the Willow-Warbler, but has the upper parts greener and the under parts less yellow in tinge, and has a conspicuous yellowish white single bar across the wing. All three of these rare stragglers are visitants from Eastern Russia and Siberia.

Educational Series.-No. 1.-OWLS. No. 2.-WOODPECKERS. No. 3.-STARLING. No. 4.SWALLOWS. NO. 5.-KINGFISHER. No. 6. -OSPREY. No. 7.-DIPPERS. No. 8.-NIGHTJAR. No. 9.-TITMICE. No. 10.-KESTREL. No. 11.-PLOVERS. No.12,-TERNS. No. 13.-WAGTAILS. No. 14.-CHOUGH. No.15.-JAY. No.16.-SKUĀS. No.17.-FLYCATCHERS. No. 18.-NIGHTINGALE. No. 19. - GULLS. No. 20. - LEAF-WARBLERS. No. 21.-PIPITS. No. 22, - SKYLARK. No. 23.-GREBES. NO. 24.-COMMON BUZZARD.

Copies of the above may be obtained from the Society's Publishing Department, Knowledge Office, 326, High Holborn, W.C., or from the Hon. Sec., Mrs. F. E. Lexon, Hillerest, Redhill, on the following terms:-Post free: three copies of any one number of the Series, 1d.; one dozen, 3d.; 100, 1s.6d. Assorted packets, one copy of any six numbers, 2d, ; one copy of any twelve, or two copies of any six numbers, $4 d$; ; or 50 assorted numbers, 1s. Special terms for larger quantities, and to County Councils, the Constabulary, and Schools. 


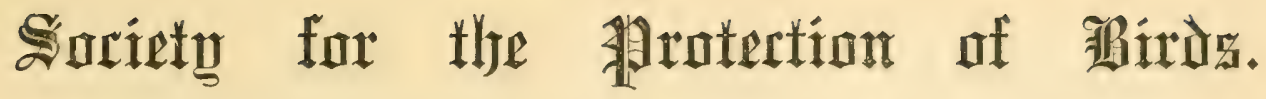

EDUCATIONAL SERIES. Edited by H. E. DRESSER, F.L.S., F.Z.S.

\section{No. 21.-PIPITS.}

By W. H. IIUDSON, C.M.Z.S.

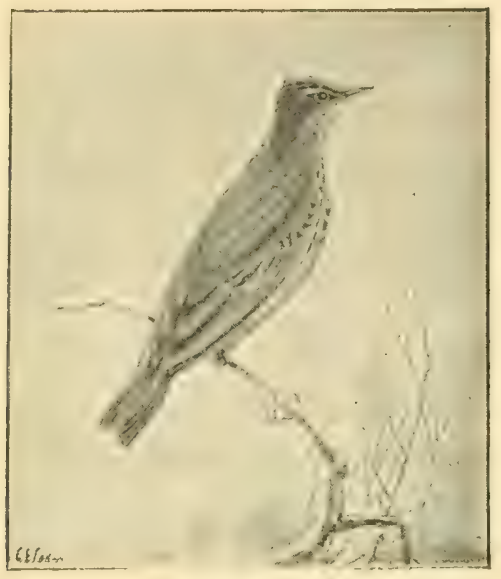

TREE PIPIT.

\section{Name.-PIPITS.}

Family-Motacillidee.

Genus-Anthus.
A. pratensis.
Meadow Pipit.
A. trivialis.
Tree Pipit.
A. obscurus.
Rock Pipit.

\section{II.-General Description.}

Mesdow Pipit.-Upper parts pale olive brown, the centre of each feather dark brown; the two outer tail feathers marked with white; under parts dull buffy white, with numerous dark brown elongated spots. Length, $5 \frac{3}{4}$ in. Hind claw longer than toe.

Tree Pipin may be distinguished from the Meadow Pipit by its slightly warmer buffish colour, and shorter hind claw. Length, 6 in.

Rock PIPIT.- Upper parts pale olive brown, the centre of each feather dark brown; under parts dull ochreous white streaked with brown. Lengtb, $6 \frac{1}{ \pm}$ in. Hind claw equal to the toe in length.

\section{Where, when, and in what numbers found.}

The Tree Pipit is a strict migrant, and is fairly common in summer throughout England, (except Cornwall and Wales, where it is scarce), on the open borders of woods, and wherever trees giow on or adjacent to meadows and grass lands. In Scotland it is more local, and

Illustrations from Hudson's "British Birds," by kind permission of Messrs. Longmans, Green \& Co. 
becomes rare in the North. In Ireland it is almost unknown. The Meadow Pipit is resident, and common in all open uncultivated places-hills, downs, moors, meadows, etc. This is the most abundant of the Pipits, being found over the entire area of the British Islands; but in winter there is a partial or internal migration, the birds that inhabit the more exposed districts moving southwards, or to more sheltered situations. The Rock Pipit is a resident, and common on all the rocky coasts of the British Islands during the summer; in winter it seeks its food on the salt marshes and on the muddy shores of estuaries.

\section{Food.}

Insects, worms, small molluses, and smali seeds, especially in winter. The Rock Pipit feeds principally on marine insects, small crustaceans, etc., picked from the seaweed.

\section{Characteristics.}

The Pipits are small, inconspicuous, shy birds; in colour, ash and neutral brown, spotted and streaked with dark brown, and all have a pale stripe over the eye. They inhabit open situations, and are earth lovers, feeding, roosting, and nesting on the ground. Their callnote is a low plaintive cheep or peep, whence their name; and to sing they soar upwards to a moderate height, and utter their notes during the descent. Their flight is swift and undulating.

\section{Protection.}

Wild Birds Protection Act, 1880.-These birds do not appear in the Schedule, but have been added in the following counties:-

Tree Pipit.-England: Lancaster; Barrow-in-Furness (C.B.); Rutland; West Suffolk. WaLES.-Brecon.

Meadow Pipit.-England : Lancaster; Barrow-in.Furness (C.B.) ; Chester (Hundred of Wirrall) ; Rutland; West Suffolk; Worcester. Scotrand : Fife (Tentsmuir).

Rock Pipit.-Engrand: Lancaster; Barrow-in-Furness (C.B.); Rutland. Wales: Brecon. Scotland : Berwick.

In these counties any owner or occupier, or other person, taking, killing, etc., any of these birds during close season,* or possessing or selling one of them after 15th March, is liable to a penalty of $£ 1$ for each bird. In any other place, anyone other than the orvner or occupier of land, or his agent, taking, killing, etc., any Pipit during close season, or possessing or selling a Pipit after 15th March, is liable to a penalty of $5 \mathrm{~s}$. for each bird.

Wild Birds Protection Act, 189 $\varpi_{1}$. The eggs are protected as follows :-

All Species.-Engrand : Breeding areas in Northumberland; York (East Riding); Cambridge; Chester; Nortolk; East Suffolk; Devon; Dorset; Essex; Kent; Isle of Wight. And in the following counties:-Wales: Pembroke. Scotrand : Orkney.

Tree Pipit.-England: Lancaster (S. of the Ribble); West Suffolk. Wales: Brecon.

Meadow Pipit.-Engrand: Lancaster (S. of the Ribble); West Suffolk. Scotland : Fife.

Rock Pipit.-England : Lancaster (S. of the Ribble); West Suffolk. Scothand: Berwick,

In the above places any owner or occupier, or other person, taling or destroying the eggs of these birds is liable to a penalty of $\mathfrak{L}^{1} 1$ for each erg.

Wild Birds Protection Āct, 1896. - In addition to any penalty under the Act of 1880 , the Court may now order any trap, net, snare, etc., used by the offender, to be forfeited.

\footnotetext{
* Generally from 1st March to 31st July; but in some counties from 1st February to 31st August in each year. A further period may be obtained through the Act of 1896 .
} 


\section{VII.-Remarks.}

The Pipits, compared with most birds of other genera, might be described by a series or negatives, since they have no special grace, nor brightness, nor anything remarkable in language and habits to distinguish them. Small, modest-coloured birdlings, shy of disposition, passing most of their time concealed among the grass, heather, and bracken in pasture lands and untilled or waste places, they are not familiar to our sight like the birds of the homestead, orchard, and field, and appear to have no special attraction. Yet in some ways they are exceedingly interesting, and are not without a charm of their own.

One striking fact concerning the Pipits is the close resemblance of one species to another. The Linnet and Twite among Finches, and the Chiffchaff and Willow-Wren among Leaf-Warblers, are not nearly so much alike as two

Pipits. And this likeness, which formerly made it difficult for our ornithologists to distinguish one from another of our British species, is not confined to the birds of our islands. The genus, or group (as it might be called) has an exceedingly wide range. Indeed the Pipits are almost cosmopolitan, since with the exception of the Polynesian subregion, which includes all the tropical islands of the Pacific, they are found in all regions of the earth. Yet in all climates and situations they are seen to be very much alike in size, form, colouring, language, flight, and life habits. This wide distribution and strong family likeness shows that the Pipits have existed almost without change for a very long period on the earth.

In appearance the Pipits are small Larks, hence the common country name of Titlark for these birds, and sometimes of Wood Lark for the Tree Pipit.

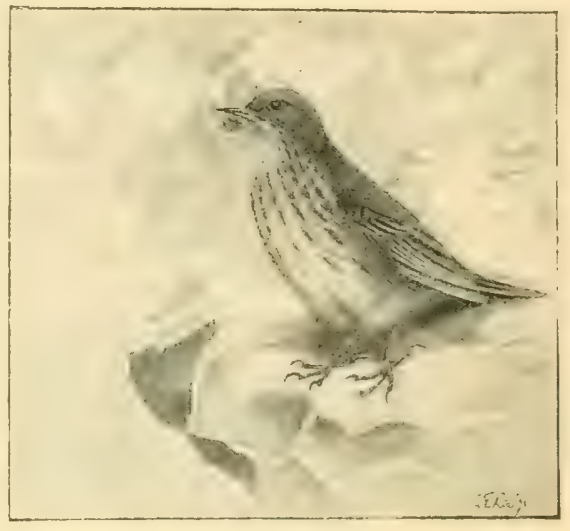

HOCK PIPIT. The early English ornithologists described the Meadow Pipit as the Lesser Field Lark; and Linnæus and his followers included the Pipits and Larks in the genus Alauda. But the resemblance is only superficial. In the more permanent characters-structure, moult, etc.-on which our modern systems are based, the two genera are uulike; and the Pipits have been remored from their neighbourhood to the Larks and placed alongside the Wagtails. This may at first seem a very arbitrary arrangement; but in the study of birds, as of many another subject, we are eventually brought, however reluctantly, to accept the truth that things are not what they seem. In their structure Pipits and Wagtails are alike, and if we closely observe, these two widely different birds we do perceive a faint family likeness, albeit one is so inferior in lustre. The finer bird has undoubtedly sprung from a humble Pipit progenitor. Certain birds of brilliant plumage and ärial habits have been called "winged gems" and "jewels of ornithology," and we may regard the Pipit as the original material, the rough pebble, which in the Wagtail has been cut to a finer shape and polished. We may see the Wagtail in the Pipit's slender bill and elongated form, in the pattern of his wing colour, the habit of moring his tail up and down, and in the swift, undulating, and often erratic flight. These characters have been intensified in the larger, brighter more volatile bird; his tail has become longer, his music louder, more impetuous and Warbler like, and to all has been added an exquisite fairy-like grace in his motions which is wholly his own.

Personally I have a great liking for the simple, obscure Pipit-greater than for some finer birds. I find in his appearance a pretty quaintness which is very attractive. But I esteem him most for his voice, which on some spring and summer days, in certain states of the atmosphere, produces a unique and beautiful effect. On extensive solitary moors in Scotland and the north of England, in boggy or marshy places, and on the south downs, especially on the Dorsetshire coast, where the Meadow Pipit is extremely abundant I have 
spent delightful days listening to its music. Each bird has a favourite stand, a low bush, a stone, or clod of earth-from which at short intervals he launches himself on the air; and rising with a repeated musical chirp to a height of fifty or sixty yards, descends slowly with wings set and motionless, emitting the sweet notes of his simple song. At a distance the voice is metallic; and on a warm, still day, when sound travels far in these silent solitudes, and the widely scattered birds within hearing are many, their voices rising and falling are like the tinkle-tinkle and chiming of small bells, with something of mystery, something aërial and fairy-like, in their tone, producing an indescribably charming effect.

In meadows and pastures where other bird-voices are heard, especially the world-flooding melody of the Skylark, the thin tinkle of the Meadow Pipit is little noticed.

The nest of dry grass is made on the ground, and four to six eggs are laid, greyish white in colour, thickly spotted, and sometimes streaked at the larger end with various shades of brown. It is the nest in which the Cuickoo most often deposits her eggs.

The Tree Pipit, although in appearance hardly to be distinguished from the last species, differs greatly from it in its song, as well as in its habit of perching on trees. There is no doubt that on their return to this country in spring these birds all repair to their old haunts to breed; a favourite spot being where large trees grow singly or in groups on or close to the grassland, where they find their food and build their nests. Like the Wood Lark, the Tree Pipit has a favourite tree to perch on; and to sing he soars up to a moderate height, and, descending, pours out his various notes, throaty or clear, and long Canary-like trills, the song concluding with one very sweet languishing note, repeated several times.

In its nesting habits this species closely resembles the Meadow Pipit. The same number of eggs, too, are laid, usually dull white is colour, spotted with brown, grey, and purple; but in colour and markings they vary greatly.

The Rock Pipit is an inhabitant of the rocky coasts, and is the only singing bird found exclusively in such places. In his song, and manner of uttering it when gliding downwards through the air, he closely resembles the Meadow Pipit; but he does not rise so high, and the voice is perhaps inferior.

The nest, composed of moss, bents, and scraps of seaweed, is built in a hole or crevice in the rocks; four or five eggs are laid, pale bluish in ground colour, thickly mottled with greyish brown or reddish brown.

Besides the three described, four other species of Pipits have been included among the casual visitors to the British Islands. These are the Red-throated Pipit $(A$. cervinus); the Tawny Pipit (A. campestris); Richard's Pipit (A. Richardi), and the Water Pipit (A. spipoletta).

Educational Series.-No. 1.-OWLS. No. 2.-WOODPECKERS. No. 3.-STARLING. No. 4.SWALLOWS. No. 5.-KINGFISHER. No. 6.-OSPREY. No. 7.-DIPPERS. No. 8.-NIGHTJAR. No. 9.-TITMICE. No. 10.-KESTREL. No. 11.-PLOVERS. No.12.-TERNS. No. 13.-WAGTAILS. No. 14.-CHOUGH. No.15.-JAY. No.16.-SKUAS. No.17.-FLYCATCHERS. No.18.-NIGHTINGALE. No. 19. - GULLS. No. 20. - LEAF-WARBLERS. No. 21.-PIPITS. No. 22. - SKYLARK. No. 23.-GREBES. No. 24.-COMMON BUZZARD.

Copies of the above may be obtained from the Society's Publishing Department, Knowledge Office, 326, High Holborn, W.C., or from the Hon. Sec., Mrs. F. E. Lemon, Hillcrest, Redhill, on the following terms:-Post free: three copies of any one number of the Series, 1d.; one dozen, 3d.; 100, 1s. 6d. Assorted packets, one copy of any six numbers, 2d.; one copy of any twelve, or two copies of any six numbers, $4 \mathrm{~d}$.; or 50 assorted numbers, 18. Special terms for larger quantities, and to County Councils, the Constabulary, and Schools.

The Society's Publishing Office, Knowledge, 326, High Holboru, Londou, W.C. 1897. 


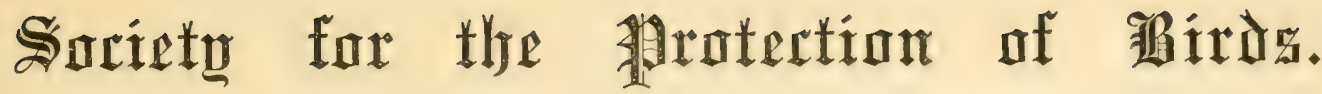

EDUCATIONAL SERIES. Edited by H. E. DRESSER, F.L.S., F.Z.S.

\section{No. 22.-SKYLARK.}

\section{By FLORENCE ANNA FULCHER.}

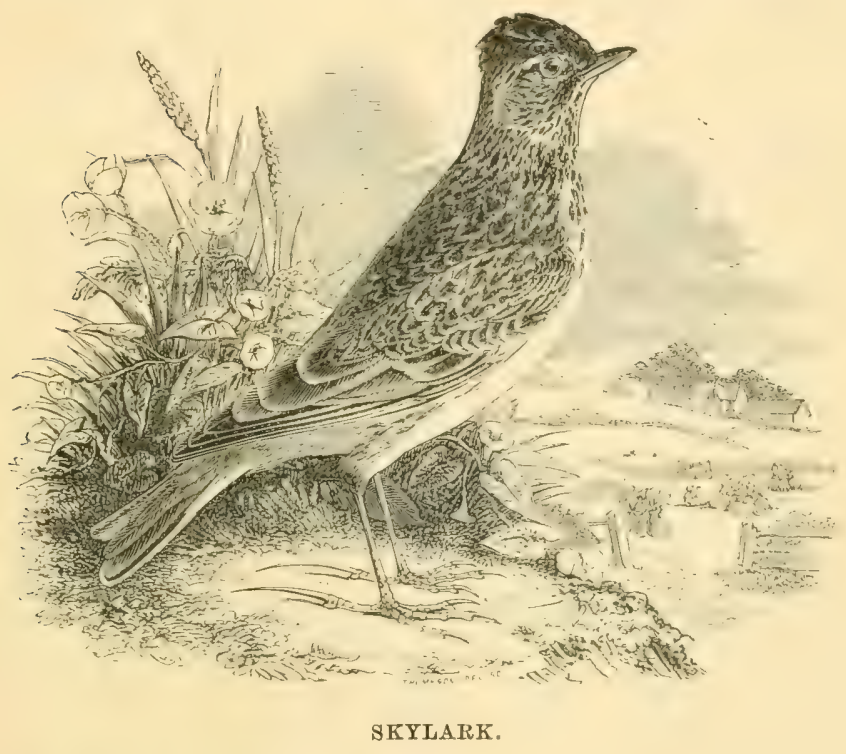

\section{Name.-SKYLARK.}

Family-Alaudide.

Genus-Alauda arvensis.

\section{General Description.}

Upper parts varied with three shades of brown, the darkest of which lies along the shaft of each feather; a faint whitish streak over the eye; throat white; under parts yellowish white tinged with brown; the throat and sides of neek with dark brown lanceolate spots, which form a gorget just above the breast. Length $7 \frac{1}{4}$ inches (W. H. Hudson). 


\section{Where, when, and in what numbers found.}

Universally and plentifully distributed over all open lands in the United Kingdom throughout the year, chiefly preferring the farm districts in the breeding season. It almost deserts its extreme northern haunts in winter, but repairs to high lands in the midland and southern counties.

\section{Food.}

A certain amount of grain, a large number of seeds of injurious weeds, an enormous quantity of grubs and insects, and the green leaves of a few small plants.

\section{y. Characteristics.}

Soaring and singing are perhaps the principal characteristics of the Slkylark as known in field, in song, and in story, but these are chiefly signs of spring and summer. Later in the year Skylarks spend most of their time running about in search of seeds and insects in the long grass and ripening corn. In autumn they "pack," and patrol the open fields in large companies. In winter these same flocks, with the migrants that have joined them, drift to and fro in search of food, and, unlike the custom of most small birds in winter, frequent high ground.

\section{Protection.}

Wild Birds Protection Act, 1880.-This bird did not appear in the Schedule, but was added by the Act of 1881, which applies to every county in England, Scotland, and Ireland.

Any owner, occupier, or other person taking, killing, etc.. a Skylark during the close season,* or possessing or selling a Skylark after March 15th, is liable to a penalty of $£ 1$ for each bird.

Wild Birds Protection Act, 1894.-The eggs are protected at present (1898) in the specified breeding areas and the following counties:-

Engtand.-Lancaster (south of the Ribble); London (including Middlesex and Metropolitan Police District).

Scotrand.-Aberdeen ; Berwick ; Elgin; Fife (Tentsmuir); Haddington ; Kirkcudbright ; Midlothian; and Wigtown.

Any owner, occupier, or other person taking or destroying the eggs of the Skylark in either of the above-named counties or specified areas is liable to a fine of $£ 1$ for each egg.

Wild Birds Protection Act, 1896. - In addition to any penalty under the Act of 1880, the Court may now order any trap, net, snare, etc., used by the offender to be forfeited.

\footnotetext{
* Gencrally from 1st March to 1st August; but in some counties from 1st February to 1st September in each year. A further period is obtainable through the Act of 1896 .
} 


\section{$\left[\begin{array}{ll}3 & ]\end{array}\right.$}

The Skylark is protected all the year round in the counties of Essex (part), London, Middlesex, and in the county boroughs of Kingston-upon-Hull, Middlesborough, South Shields, and Cardiff.

\section{Remarks.}

There are still Larks at heaven's gate singing! Judging by the ordinary laws of probability the English Skylark ought long ago to hare gained the distinction that belongs to the Dodo and the Great Auk, for the Lark abides in the midst of foes. Day by day all through the winter the birdcatchers are at work to supply the demand for caged Larks. The birds eaught by day form, however, but an inconsiderable proportion of the total number netted and trapped; by far the greater mass of the birds that are sent in sackloads to all the great markets for table purposes, as well as the thousands that are sold alive, are taken at night while they are roosting on the ground. They are then caught by hundreds at a time, by means of nets dragged over the grass. The sale for these little birds is inconceivably large; hundreds of thousands find their way yearly to the poultry markets; others are sold for the sake of their wing feathers, which are dyed to counterfeit those of tropical species; and many live birds find purchasers among the lowest classes in great towns, who keep birds for the degrading practices of betting on their respective powers of song, and of letting them fly at shooting matches.

It was stated in a London newspaper in March, 1891, that the London markets alone were at that time receiving more than forty thousand Larks daily, which arrived at Leadenhall Market in sacks, and were sold to the poulterers by bushel measure. The number of Larks taken for the feather market and trade in live birds is probably as great.

It is obvious that this cannot continue indefinitely. Notwithstanding the extraordinary pertinacity with which birds continue to people a district which suits them, against many and great odds (in the case before us filling up thinned ranks with birds bred in the vast nurseries of Scanainavia), extermination must eventually follow such methods; but there is still time to avoid such a catastrophe. There are still flocks of native Larks patrolling English fields, when their migrant brothers from far northern lands are dropped like feathers from the wings of the autumn wind; there are still English Larks building their round grassy nests and laying their four or five grey eggs in almost every English field. Let us consider, ere it be too late, if it be worth while to avert this threatened loss. It is not from a sentimental point of view only that the question of protection for the birds must be approached, even by those who value them as one of nature's best modes of expressing poetic thought and beauty, and something more that we can neither name nor fathom. Let this pass, therefore, and let us consider how the little creature that sings at hearen's gate is hard at work at earth's portal.

The economic value of insectivorous birds is untold, and it is for its work in this direction 


\section{$\left[\begin{array}{lll}4 & \end{array}\right]$}

during the winter that the laark is so precious. In the summer its work is shared by many, but as winter draws near and the summer migrants desert, the task of catching the metamorphic insect devolves upon those species of birds that winter here. Rook, plover, thrush, and lark are invaluable then, for when the leaves have fallen and the fruit is stored, in the grass insect life is still abounding, and in its most dangerous form. Hidden in the tussocks of grass, or lightly covered by a thin layer of earth, myriads of insects are wintering, most of them in the second or larval stage of their destructive lives, and most voracious. Caterpillars, grubs, and maggots have abnormal appetites; their greed is insatiable, and they seem capable of devouring a mass of food out of all proportion to their bodies. They also reach the maximum of mischief by other devices, for as well as developing this unconscionably gross manner of feeding, they learn to worm their evil way into the very vitals of the plants they attack. Some remain there for a few hours, some for weeks or months, while others maintain their coign of vantage for several years, among the latter the wireworm being notorious. It is to the grass-haunting birds that we must chiefly look to destroy insects at this dangerous stage; the field birds, among which the Lark, though small in stature, is not least, render incalculable service then.

When the crops of Larks are opened they are often found to contain wheat, but the seeds of noxious weeds also discovered make handsome amends for that; and the proportion of vegetable matter, both lawful and contraband, is small compared to the mass of grubs, caterpillars, chrysalises, as well as fully developed insects, nearly all more or less destructive, that the birds are found to have eaten. Such a tale points its own moral.

The Lark arising from its dewy bed to hymn the morning sun has won the title of Alauda-bird of song; arvensis it earns by its care of field and fallow. Surely we have for it a word of praise and a little care to save its frail life from destruction.

Educational Series.-No. 1.-OWLS. No. 2.-WOODPECKERS. No. 3.-STARLING. No. 4.SWALLOWS. No. 5.-KINGFISHER. No. 6.-OSPREY. No. 7.-DIPPERS. No. 8. -NIGHTJAR. No. 9.-TITMICE. No. 10.-KESTREL. No.11.-PLOYERS. No. 12.-TERNS. No. 13.-WAGTAILS. No. 14.-CHOUGH. No.15.-JAY. No.16.-SKUAS. No.17._FLYCATCHERS. No. 18,-NIGHTINGALE. No. 19.-GULLS. No. 20.-LEAF-WARBLERS. No. 21.-PIPITS. No. 22.-SKYLARK. No. 23.-GREBES. No. 24.-COMMON BUZZARD.

Copies of the above may be obtained from the Society's Publishing Department, Knowledge Office, 326, High Holborn, W.C., or from the Hon. Sec., Mrs. F. E. Lewon, Hillerest, Redhill, on the following terms:-Post free: three copies of any one number of the Series, 1d.: one dozen, 3d.; 100, 1s. $6 \mathrm{~d}$. Assorted packets, one copy of any six numbers, 2d.; one copy of any twelve, or two copies of any six numbers, $4 d$. ; or 50 assorted numbers, 1s. Special terms for larger quantities, and to County Councils, the Constabulary, and Schools. 


\section{Soriety for the Arotertion of gefirdy.}

EDUCATIONAL SERIES. Edited by H. E. DRESSER, F.L.S., F.Z.S.

\section{No. 23.-GREBES. \\ By JOHN R. B. MASEFIELD, M.A., Vice-President North Staffordshire Field Club.}

"The Great Crested Grebe is the greatest ornithological ornament of our county."-McAldowie, "Birds of Staffordshire."

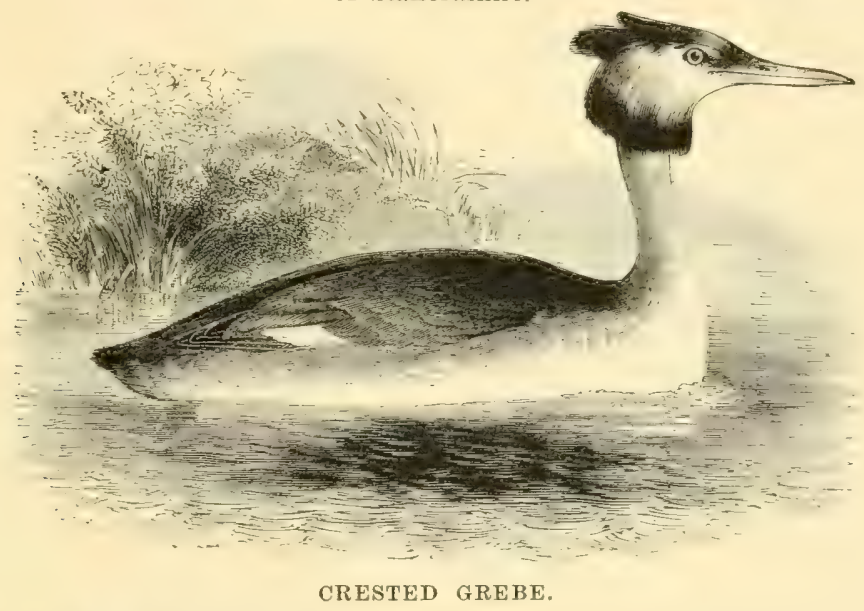

\section{Name.-GREBES.}

Family-Podicipedidie.

Genus-Podiceps.

\section{General Description.}

P. crislatus, Great Crested Grebe.

$P$. griseigena. Red-necked Grebe,

$P$. auritus. Selavonian Grebe.

P. nigricnllis. Eared Grebe,

$P$. fluviatilis, Little Grebe.

Great Crested Grebe.-Crown and crest dark brown; tippet chestnut, liackish at the margin ; upper parts dark brows; secondaries and carpals, white; under parts satiny white; bill, dark above, reddish horn at the sides; irides red. Total length, 22 inches; wing, 8 inches. Female rather smaller, the crest and tippet less developed. Young striped above, white below.

Red-neched Grebe.-Distinguished from the Great Crested Grebe by the neck in front and upper portion of the breast being chestnut-red, by its rather smaller size and shorter crest. Cheeks and throat, greyish blue; crown and crest, dark greenish black. Length, $16 \frac{1}{2}$ inches; wing, 7 inches.

Sclavonian Grebe.-Crown, forehead, chin, and tippet, black; a tuft of chestnut on each side of the head; neck, breast, and flanks, chestnut; under parts, satiny white. Female smaller, with the head ornaments less developed. Length, $13 \frac{1}{2}$ inches; wing, $5 \frac{1}{2}$ inches. 
Eared Grebe.-This Grebe is easily distinguished from the Sclavonian Grebe by the bill being gradually turned upwards to the tip, and also by the throat and upper part of breast being black instead of chestnut. Jength, 12 inches; wing, 5 inches.

Littue Grebe.-In summer the adult has the head, neck, and upper parts dark bruwn; throat and sides of neck and head, chestnut; chin, black; under parts, white; flanks, dusky; bill-horn, yellowish at gape ; iris, reddish brown; legs, dull green. Length, $9 \frac{1}{2}$ inches; wing, $4 \frac{1}{4}$ inches. In winter much paler, and the head and neck are brown; the chin, white. The young are dark brown, streaked with yellowish brown.

\section{Where, when, and in what numbers found.}

The Great Crested GrebF.-This bird, more generally called "Loon" or "Diver," is mostly a summer visitant, especially on meres, large pools, and reservoirs in Staffordshire, Cheshire, Shropshire, and Yorkshire, the Broads of Norfolk and Suffolk, and the Lakes of Wales; but it frequently remains as a resident during the winter, unless driven away by frost and ice, when it migrates to the larger rivers and estuaries, and the sea coast. In winter it is met with on the east coast ; in the North it becomes rarer, and is of rare occurrence in Scotland. In Ireland this bird is not uncommon on some of the larger lakes, where it breeds.

ReD-NECKed Grebe.-A winter visitant to our east and north-east coasts, and in severe winters in some numbers. In Scotland it is not uncommon on the east coast, and is very rare in Treland.

Sclatonian GreBe.-A winter and spring visitant to our east and north-east coasts, and more frequently observed up the east coast of Scotland. Occasionally in Ireland.

Earfy Grebe.-A very rare and accidental visitant to the British Isles on spring and autumn migration.

Little Grebe.-More generally known as the "Dabchick" or "Jack Doucker." This is the commonest of our Grebes, and resideut on most lakes, meres, ponds, and reedy streams in England, Scotland, and Ireland. When frozen out it migrates to the swifter streams, rivers, and estuaries.

\section{IV.-Food.}

The food of all the Grebes consists of small fish, young fry, water insects and their larvæ, tadpoles and young frogs, water snails, and the seeds and tender shoots of water weeds. When on the coast, marine crustacea or fish, and molluses, form the principal food. A Norfolk naturalist has truly said: "No perceptible injury is done by these birds, and nobody insinuates there is, and their beauty and appropriateness to Broadland amply atones for what they may devour." In the destruction of insects and seeds of water weeds they undoubtedly render a great service to man.

\section{Y. Characteristics.}

Undoubtedly the chief characteristies of the Grebes is their wonderful power of diving, for which they are so specially formed, both on the approach of danger, and also when in search of food, and on this power they seem to rely for preservation. When alarmed, the Great Crested Grebe instinctively sinks its body underneath the surface of the water, leaving only the head and neck or part of the neck above. If further alarmed the bird at once dives, appearing again at a distance of 50 or 100 yards, and continues this operation until it feels at a safe distance away. This habit is unfortunately sometines taken advantage of by gunners, who row down the bird by means of a boat until it is exhansted, and comes within range and is shot. The Little Grebe when in danger instantly dives, and so quickly can this be done that the little bird frequently escaped between the flash and the deadly shot of the old flint grm. On coming to the surface with scarcely a ripple, the dive is repeated, and the bird takes advantage of a water-lily or other aquatic leaf under which to conceal itself, with the beak only above the 
surface of the water and underneath the leaf, to enable the bird to breathe. Another characteristic of the Grebes is their apparent unwillingness to take wing or to come upon land. At the same time their power of flight is undoubted by reason of their migration, and of the sudden appearance of some of the species on pools and lakes many miles from any other water. When flying the Grebe strongly resembles a duck. The Great Crested Grebe forms a somewhat substantial floating mass of water weeds, rushes, reeds, dead sticks, and aquatic plants on which to nest among the reeds. The eggs are four to fire in number, chalky white when laid, but soon becoming mud-stained and discoloured by the decaying regetable matter composing the nest. On being disturbed from off the nest the hen bird with her beak hurriedly covers over the eggs with weed, especially after the full complement of eggs is laid. The young take to the water almost as soon as they are hatched. The Little Grebe nests amongst the weeds, and often in very exposed situations, apparently trusting to the resemblance of the nest (which is entirely composed of floating water weeds) to its surroundings to escape notice. This little bird also covers over its eggs when leaving the nest. The eggs are five to six in number, dead white when laid, but they soon become stained a muddy colour. On approach of danger the hen bird frequently takes her young under her wing and dives, taking them with her to a place of sufety. There is no conclusive evidence of the three rarer species of Grebe ever having bred in this country.

\section{Protection.}

Wild Birds Protection Act, 1880.-All the Grebes are included in the schedule, which applies to every county in England, Scotland, and Ireland. Any owuer, occupier, or other person, taking, killing, etc., a Grebe during the close season, * or possessing or selling a Grebe after the 15th of March, is liable to a penalty of $£ 1$ for each bird.

Wild Birds Protection Act, 1894.-The eggs of the Grebes are protecter in the following counties and county boroughs:-

Grebes of all Species.-England.-Northumberland, Holy Island; †York, East Riding; York, West Riding; Huddersfield; +Cambridge; †Chester ; +Norfolk ; †East Suffolk; West Suffolk; +Devon; tEssex; Herts (not within M.P.D.) ; †Kent ; tIsle of Wight; and tEast Sussex.

Scotland.-Orkney.

IRELAND.-Roscommon.

Great Crested Grebe also in-EvgLAND.-Leicester; Norfolk; Stafford; Salop; Worcester ; East Sussex ; and Hastings.

Scotland.-Dumfries; Fife; Kincardine; Kirkcudbright; Peebles ; Perth ; Stirling; Wigtown.

Sclavonian Grebe also in-EngLAND.--Worcester.

Little Grebe also in-EngLand.-Leicester; Worcester ; Dorset.

Wales. - Pembroke.

Scothand.-十Argyll; Dumbarton; Fife ; Lanark; and Stirling.

\footnotetext{
* Generally from 1st March to 31st Jul 5 , but the close season has been extended in many counties, and in several extends to the whole year, affording these birds absolute protection all the year round.

+ Indicates that only in a specified area in the county are the eggs protected.

Illustration by kind permission of Messrs. Longmans, Green, \& Co., from "British Birds," by

W. H. Hudson, C.M.Z.S.
} 


\section{$\left[\begin{array}{ll}4 & ]\end{array}\right.$}

Any owner, occupier, or other person, taking or destroying the eggs of these birds in the above places is liable to a penalty of $£ 1$ for each egg.

Wild Birds Protection Âct, 1896.-In addition to any penalty under the Act of 1880 , the Court may now order any trap, net, smare, etc, used by the offender, to be forfeited.

The Great Crested Grebe and the Little Grebe are both protected all the year round in the County of Stafford, and the Little Grebe in East Sussex ; and Hastings (C.B.).

\section{Remarks.}

How lifeless would be our lakes, meres, and broads-and in fact all our inland sheets of water-without their bird life! With what pleasure do we always point out the Coot, the Water Hen, the Wild Duck, and the elegant and ornamental Grebes, swimming upon the water, often attended by their brood of young. And yet, that tyrant, "fashion," has greatly diminished the numbers of these birds, and travelling round, as fashion does, in cycles of years, it is once more taking a deadly toll of these poor birds. The beautiful soft and silky texture of the breast feathers of the Grebes has once more caused woman's love of novelty to select these skins as trimmings for her dress, with the result that during the last two or three years hundreds of thousands of Grebes have been sacrificerl to the goddess Fashion, and their young, probably, left to perish by a slow, lingering death of starvation, the feathers of birds being in their brightest sheen during the nesting season. Most of these Grebe skins have been supplied from Russia and the North of Europe, and North America, the principal homes of the Grebes ; but our own native birds have, no doubt, also been called upon to provide their share to meet fashion's remorseless demand. Thanks to some of our County Councillors, some protection is now afforded to these birds, but we do appeal to woman's better feelings and better nature, as well as to her well-known tender heart, to do all in her power (and women really have it in their power to put a stop to this seuseless and cruel fashion) to allow us to still have the pleasure of admiring our native birds in their natural freedom. One word, tro, to the owners of inland sheets of water where our Grebes are found, as to preserving them as sanctuaries for these birds, their eggs and young, so that they may afford a pleasure not only to the proprietors themselves, but also to all lovers of nature. The quotation from Dr. McAldowie at the heading of this pamphlet is a truth which every landowner should bear in mind; for if once these birds are shot, or driven away by persecution, they cannot be reintroduced, as many other wildfowl may be, by man, and "a thing of beauty" which " is a joy for ever" will be lost for ever, as is already the case with the Crane, the Egret, the Avocet, the Spoonbill, and so many more of those beantiful birds which were once ornithological ormaments of our inland waters.

Educational Series.-No. 1.-OWLS. No. 2.-WOODPECKERS. No. 3.-STARLING. No. 4.SWALLOWS. No. 5.-KINGFISHER. No. 6.-OSPREY. No. 7.-DIPPERS. No. 8.-NIGHTJAR. No. 9. -TITMICE. No. 10.-KESTREL. No. 11.-PLOVERS. No. 12.-TERNS. No. 13.-WAGTAILS. No. 14.-CHOUGH. No. 15.-JAY. No.16.-SKUAS. No.17.-FLYCATCHERS. No. 18.-NIGHTINGALE. No. 19. - GULLS. No. 20. - LEAF-WARBLERS. No. 21. - PIPITS. No. 22. - SKYLARK. No. 23.-GREBES. No. 24.-COMMON BUZZARD.

Copies of the above may be obtained from the Society's Publishing Department, Knowledge Otfice, 326, High Holborn, W.C., or from the Hon. Sec., Mrs. F. E. Lemon, Hillerest, Redhill, on the following terms:-Post free: three copies of any one number of the Series, 1d, ; one dozen, 3d.; 100, 1s, 6d. Assorted packets, one copy of any six numbers, 2d.; one copy of any twelve, or two copies of any six numbers, $4 \mathrm{~d}$; ; or 50 assorted numbers, 1s. Special terms for larger quantities, and to County Councils, the Constabulary, and Schools.

The Society's Publishing Oflice, Knowledge, 326, High Holborn, London, W.C. 1897. 


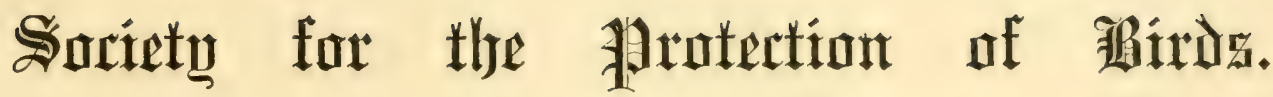

EDUCATIONAL SERIES. Edited by H. E. DRESSER, F.L.S., F.Z.S.

\section{No. 24.-COMMON BUZZARD.}

By Rev. H. A. MACPHERSON, M.A., Author of "A History of Fowling," "The Fauna of Lakeland," etc., Joint-Author of the "Fur and Feather Series," etc.

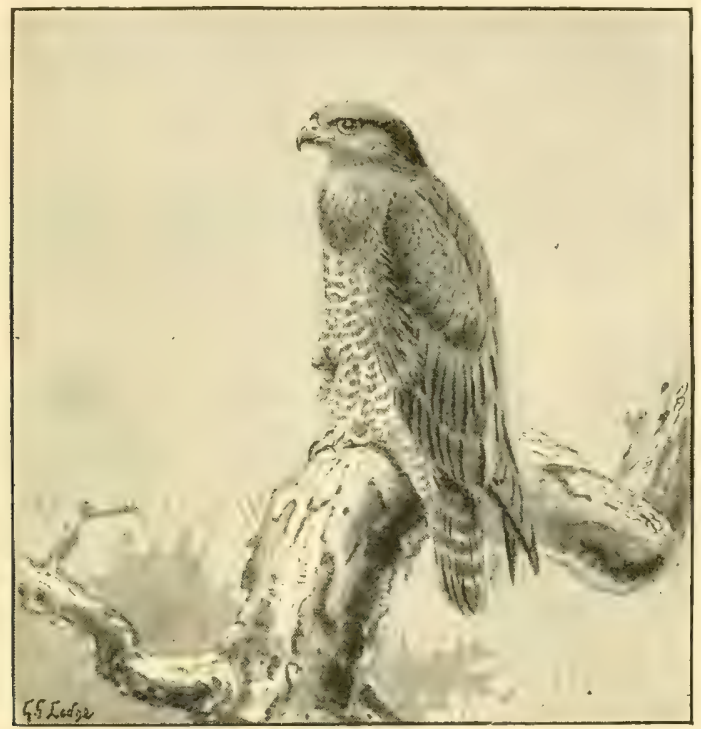

COMMON BCZZABD.

\section{Name-COMMON BUZZARD.}

Family-Faleonidx.

Genus.-Buteo. Buteo vulgaris. Common Buzzard, Glede, Shreak.

\section{General Description.}

Buzzards vary immensely in individual coloration. The British species varies more than any of its numerous allies. The nestling is at first covered with white down, which is replaced by a lighter or darker phase of plumage, as the case may be. The commonest form has the feathers of the upper parts dark brown, the back, secondaries, and wing-coverts edged with chestnut. The feathers of the lower parts are dark brown clouded with buff. The amount of rufous in the tail

Illustration by kind permission of Messrs. Longmans, Green, \& Co., from "British Birds" by W. H. Hudson. 
varies. Three fine adults in the Carlisle Museum agree in having the upper parts dark brown, but differ widely as to the colour of the feathers of the breast. The first has the throat and breast buff, varied with bold black blotches. The sezond has the breast dark brown, but the rest of the lower parts are warm buff, with dark arrow-shaped markings. A third has the entire under-surface dark brown, blotched and barred with buff. White and black varieties are of rare occurrence.

\section{Where, when, and in what numbers found.}

This Buzzard is resident in most parts of temperate Europe. It is replaced in the extreme North by the Rough-legged Buzzard (Archibuteo lagopus), easily recognised in the hand by its feathered legs. The range of the Common Buzzard is regulated by the abundance or seareity of the small mammals which form its chief means of subsistence. We found it a common bird in Spain, in France and Germany, principally in forest districts. It formerly resided in all the wooded counties of England, and that long before man appeared upon the scene. Its bones have been disinterred from a cave in the Lake district, along with those of the wolf and many other wild animals. Centuries of persecution bave compelled our British Buzzards to desert the forest wilds which in earlier days contained the bulliy nest.s of their race, and to rear their broods upon the shelves of dizzy precipices. At the present time the Buzzard is tolerably numerous in Scotland and the West of England, but is relatively scarce in Ireland.

\section{Food.}

The idea that every hawk preys upon winged game is a fallacy. The Buzzard does not subsist upou birds at any season. Its diet is perfectly well known. It feeds largely on dead deer, and on the sheep which fall over the rocks. In the absence of carrion, the Buzzard feeds principally upon field voles and small rabbits. It also consumes rats, water voles, longtailed field mice, and other small quadrupeds. The Buzzards which we skinned in Spain had their stomachs crammed with wall lizards (Lacerta muralis). Beetles and other insects are also included in the Buzzard's menu.

\section{Characteristios.}

The Buzzard is in popular parlance a big, slow-winged, brown hawk, devoid of the dashing character which marks the nobler Falcons. It never quarters the ground like a Harrier, but either perches slugyishly upon the branch of so.n s small tree upon the face of a broken cliff, or slowly circles round at a great height in the air. Its presence is nearly always announced, even whın the bird is flying through the mountain mist, by the reiteration of its loud and melancholy cry.

\section{Protection.}

Wild Birds Act, 1880.-This bird does not appear in the schedule, but has been added in the following Counties :-

England :-Cumberland; Durham; Lancaster; York (West Riding); Bedford ; Buckingham; Lineoln (Kesteven and Lindsey); Northampton; Soke of Peterborough; Rutland; West Suffolk; Devon; Hertford; Kent; Metropolitan Police District (including Lon lon and Middless) ; Sumerset; East Sussex; Wiltshire; and the County Buroughs of Barrow-in-Furness; Huddersfield; Hastings.

WALES :-Pembroke. 
Scotrand:-Banff; Dumfries; Elgin; Fife (Tentsmuir); Kirkcudbright; Peebles ; Roxburgh; Selkirk; Sutherland; Wigtown.

In these counties any owner, occupier, or other person taking, killing, ete., a Buzzard during close season,* or possessing or selling a Buzzard after 15 th March, is liable to a penalty of $£ 1$ for each bird.

Wild Birds Act, 1894.- Its eggs are protected at present in the following counties: $\nmid$ -

England:-Cumberland; Durham; Lancaster; Westmoreland: +York (East Riding); York (West Riding); Bedford; Gloucester ; Leicester ; Liucoln ; (Kesteren and Lindsey); Norfolk; Northampton; Solie of Peterborough ; Stafford; East Suffolk; West Suffolk; Warwick; Devon; tEssıx; Hertford; Kent; Metropolitan Police District (including London and Middlesex); Southampton; East Sussex; and County Boroughs of Barrow-in-Furness; Huddersfield; Hastings.

WALES :-Brecon.

Scothand :-Banff; Dumfries; El cin ; Fife (Tentsmuir) ; Kincardine ; Kirkcudbright; Peebles ; Roxburgh; Selkirk; Sutherland; Wigtown.

Any owner, occupier, or other person, taking or destroying a Buzzard's egg in these counties is liable to a fine of $£ 1$ for each egg.

Wild Birds Act, 1896.-In addition to any penalty under the Act of 1880, the Court may now order any trap, net, snare, etc., used by the offender to be forfeited.

The Buzzard is protected throughont the whole year in the Counties of Gloncester; Devon; Essex (part); London; Middlesex; East Sussex; Flint; and the County Boroughs of Kingston-upon-Hull; Hastings; Cardiff.

\section{Remarks.}

The protection of the larger birds of prey can rarely be secured, except through the forbearance of those who, as large owners of land, are most keenly interested in preserving game. The sportsman who pays exorbitant rates upon the supposed sporting value of his estate, and who has further to prevent his game from being exterminated by maintaining a costly staff of keepers and watchers, has it greatly in his porver to decide whether the Buzzard and other rapacious birds should be allowed to increase and multiply upon his estate. If, then, it could be proved that the Buzzard habitually destroyed game, reason is that we should throw up the brief which we hold for its defence. But happily the Buzzard does not destroy game; on the contrary, all our experience goes to prove the facts lidid bare in the stomachs of the Buzzards which we have personally dissected (there is all the difference in the world between the mere compiler and the man who writes from a wide knowledge of substantial facts), that the Buzzard lives on small but harmful mimmuls, and on carrion. Of course the Buzzard kills rabbits, principally small ones, when it can get them; but this is in its favour. Rabbits do immense harm to sheep pasture, rot only because they eat a quantity of grass during the spring months when food is scarce, but also by defiling the pasturage, which sheep refuse to eat in consequence. The short-tailed fieldmouse or vole is most injurious to hill pastures, and would multiply enormously were it not for the exertions of Buzzards, Kestrels, and Owls. The Buzzard is a friend to the farmer, and well worth encouriging on that score. But there is yet another reason why the haml of the destroyer should be arrested, before he fixes the iron gin to trap the harmless and useful Buzzard. Much of our wildest and most beautiful scenery would seem cold and lifeless, were it not for

* Generally from 1st March to 31st July, but in some counties from 1st February to 31st August in each year. A further period may be obtained through the Act of 1896, as in Middlesex.

+ In counties marked thus there is a specified ares within which protection is granted. 
the presence of the shy creatures which, driven from more sheltered asylums, seek to continue their race among beetling scaurs and desolate uplands. The Buzzard-where does she nestle upon her prettily blotched eggs? Far away among the shadows of the pathless hills, where the muirfowl crows unheeded, where the red deer hinds file along the mountain side, and the fox creeps through the loose screes, intent upon surprising the blue hare that cronches in the heather in short-livel security. The male Buzzard sreeps through the adjacent strath, or challenges his mate to soar aloft in his company, circling round with the least possible expenditure of exertion. When one of a pair is killed, the survivor wails in lonelimess among the passes of the hills until time heals its sorrow by providing a new mate. Day after day the freshly united couple may be seen hunting in company, but they will most likely defer further nesting plans to another spring. If they succeed in escaping the teuder attentions of the inveterate egrocollector, you may enjoy the evolutions of the whole family, until the approach of autumn tempts the young birds to wander to fresh districts. But the old birds will remain year after year in their accustomed haunts, nesting in one or other of their ancestral eyries; and at other times coming in to roost just before dusk in their favourite niches among the crags. A wild, free life is that of the Buzzard, ever gliding through the air in easy circles, or poised upon the projecting pinnacle of some sea-washed precipice. Why should the charm of its fine presence be withdrawn from the mountain or the lonely island-shore, seeing that it is harmless to game, and a friend to the hard-pressed agriculturist? Game preserver's have nothing to gain by effecting or permitting its extermination. The world is the poorer for every Buzzard that yields up its innocent life in the keeper's trap.

Note.-How fully the utility of the Buzzard is understood in Germany is evidenced by the title it bears, "Der Mäuse Bussard": anglice, the Mouse Buzzard.-ED.

\section{E D UCA T IO NA L SERIES.}

Edited by H. E. DRESSER, F.L.S., F.Z.S., PART T.

I. OWLS, by Montagu Sharpe, J.P., D.L.

2. WOODPECKERS, by Sir Herbert MaXwell, Bart., M.P.

3. STARling, by O. V. Aplin, F.L.S., M.B.O.U.

4. SWALlows, by Thomas Southivel, F.Z.S.

5. Kingfisher, by Sir Edward Grey, Bart., M.P.

6. OSPREY, by J. A. HARVIE-Brown, F.R.S.E., F.Z.S.

7. Dippers, by W. Lock Mellersh, B. A.

8. NightJaR, by Montagu Sharpe, J.P., D.L

9. TITMice, by Sydney Buxton, M.P.

10. Kestrel, by Rev. J. E. Kelsall, M.A.

II. PLOVers, by Joseph A. Pease, M.P.
PARTII.

12. TERNS, by Thomas Southwell, F.Z.S.

13. WAGTAILS, by WARDE Fowler, M.A.

14. CHOUGH, ly J. A. Harvie-Broivn, F. R.S.E. F.Z.S.

I5. JAY, by John Cordeaux, M.B.O.U.

I6. SKUAS, by T. E. BUCKLEY, M.A., F.Z.S.

17. FLYCATCHERS, by J. R. B. MASEFIELD, M.A.

i8. Nightingale, by J. H. Allchin, Bentlif Curator, Maidstone Museum.

19. GULls, by Howard Saunders, F.L.S., F.Z.S. 20. LEAF-WARBLERS, by H. E. DRESSER, F.L.S., F.Z.S.

2i. PIPITS, by W. H. Hudson, C.M.Z.S.

22. SKYLARK, by FLORENCE ANNA FULCHER.

23. GREBES, by J. R. B. MASEFIELD, M.A.

24. COMMION BUZZARD, by REV. H. A. MAC. PHERSON, M.A.

Wild Birds Protection Acts and Orders, I880 to I896, wich Explanatory Notes, and Supplement by F. E. Lemon, M A, LL.B. Price 2d. Either part separately, Id. each.

Copies of the above Series may be had from the Society's Publishing Department, K'noweledse Office, 326, High Holborn, W.C., or from the Hon. SEc., Mrs. F. E. Lemon, Hillerest, Redhill, on the following Terms :-Post Free : 3 copies of any one number of the series, 1d.; I Dozen, 3d. ; Ioo, 1s. 6d. Assorted Packets: I copy of any six numbers, 2d. ; I copy of any twelve, os 2 Copies of any six numbers, 4d. ; or fifty assorted numbers, 1s. Paris I and 2 (in covers), 1s. each.

Special Terms for Larger Quantities, and to Countv Councils, the Constabulary, Schools, and Educational Bodies. FEBRUARY, 1898. 

OVER-DETENTION TWO CENTS A :

Fnn- BELOW ARE ?

t? 


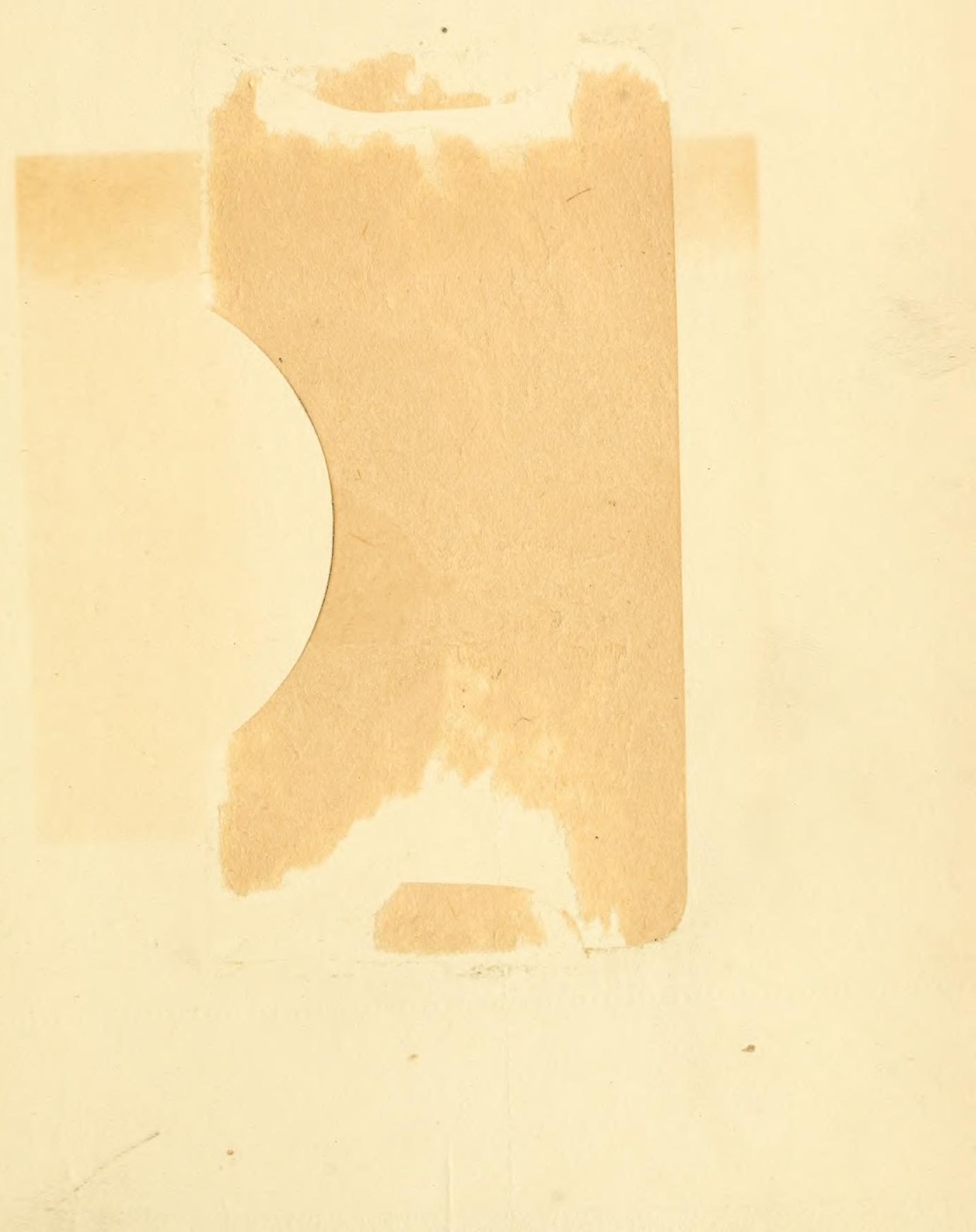


